\title{
Trace Elements in Marine Sediments from the Oxfordian (Late Jurassic): Implications for Seawater Chemistry, Erosional Processes, Changes in Oceanic Circulation and More
}

\author{
Barbara Müller
}

\author{
Geological Institute, Swiss Federal Institute of Technology, 8092 Zürich, Switzerland
}

\begin{abstract}
The Oxfordian, first stage of the late Jurassic, is remarkably variable in terms of deposited sediments, geochemical tracers, and climate. The climate changed during the Middle Oxfordian from humid to arid with a temperature rise of more than five degrees. During this time, the $\partial^{13} \mathrm{C}$ reached maximum values. The positive excursion in $\partial^{13} \mathrm{C}$ of carbonates from the Oxfordian (with an amplitude of more than $1 \%$ ) was reproduced in hemipelagic sections from southeastern France. Analysis of major and trace elements of these carbonates were carried out by LA-ICP-MS in order to verify their application as palaeoproxies in conjunction with the changes mentioned in climate. As a novel approach 36 elements were measured with regard to establish a complete and comprehensive analysis of the geochemical situation. Concentration peaks of $\mathrm{P}, \mathrm{Sr}, \mathrm{Mn}, \mathrm{Fe}, \mathrm{Ba}$ point to a more oligotrophic setting within the lower part of the sediment profile from southeastern France. Conversely, the positive $\partial^{13} \mathrm{C}$ excursion with $\partial^{13} \mathrm{C}$ values rising from 2 to $3 \%$ within the uppermost part of the profile coincide with more elevated concentrations of $\mathrm{V}, \mathrm{Fe}, \mathrm{Mn}, \mathrm{U}$ arguing for an ocean-wide anoxia (Oceanic Anoxic Events OAE). High detrital input during this arid period is recorded by enhanced concentrations of elements like $\mathrm{Ti}, \mathrm{Mn}, \mathrm{Fe}, \mathrm{Zr}, \mathrm{Nb}$ and $\mathrm{W}$. This correlation of the $\partial^{13} \mathrm{C}$ excursion with trends in $\mathrm{Ti}, \mathrm{Nb}, \mathrm{W}$ as well as $\mathrm{Mn}$ and $\mathrm{Fe}$ contents reflects changes in the Oxfordian palaeooceanography and climate. During the late Oxfordian the environmental prerequisites were controlled by warm and arid conditions and an increased metal flux from the continent due to the intensified chemical and physical weathering, erosion of rocks, as well as aeolian and fluvial transport to the oceans.
\end{abstract}

Keywords: Oxfordian, carbon isotopes, trace elements, palaeoproxies, climate change, ocean-wide anoxia.

\section{INTRODUCTION}

The Oxfordian ( 160 to 155 m.y. BP, the first stage of the Late Jurassic) was a time of widespread, globally near synchronous change in the marine (carbonate) sedimentation pattern [see 1 and references therein]. One of the most striking features of this time interval is the switch from dark and clayey or siliceous carbonate-poor sediments to light grey, carbonate-rich deposits. This peculiar switch, which is very distinct and obvious in the field, defines the boundary between "brown" and "white" Jurassic - reflecting the fundamental global changes the world was undergoing at that time [1]. The sudden and widespread changes in the marine carbonate sedimentation pattern, therefore, must be part of a response of the ocean-atmosphere-solid earth system to internal or external forces [see 1 and references therein]. In the European Tethys province, the late Callovian and Early Oxfordian are distinguished by reduced carbonate deposition: sediments are either absent, condensed and ironrich or were built as thick, organic carbon-rich shaly (e.g. "Terres Noires") or siliceous deposits (e.g. radiolarites). Later, in the middle to late Oxfordian, a change to widespread carbonate sedimentation occurred. This well documented change in sedimentation pattern seems to correlate with a positive anomaly in both marine and

*Address correspondence to this author at the EAWAG, Swiss Federal Institute of Aquatic Science and Technology, 8600 Dübendorf, Switzerland; Tel: +41(0) 7965670 54; E-mail: barbara.mueller@eawag.ch terrestrial carbon-isotope records of the middle Oxfordian [1].

Moreover, the climate was also undergoing major changes during the Oxfordian: the Late Callovian-Early Oxfordian was characterized as a cold and humid period and was replaced by a considerably warmer and more arid climate in the middle-late Oxfordian. This change led to increased metal flux from the continent due to the intensified chemical weathering due to the higher temperatures and enhanced erosion rates [1,2 and references therein]. Along with the ongoing opening of the Atlantic and the Tethys, the Late Jurassic long-term sea-level rise led to a reorganization of ocean currents in the Tethys-Atlantic system during the Oxfordian [1].

Carbon-isotope records of marine carbonate are a useful proxy of the carbon cycle. In Louis-Schmid et al. [1] the authors investigated detailed C-isotope records of the early to middle Oxfordian from France and Switzerland. They studied the relationship between $\mathrm{C}$-isotope evolution, facies changes, carbon cycling and sea level, followed by a discussion of mechanisms responsible for the mid-Oxfordian positive C-isotope excursion.

The study [1] was centered on the northern margin of the Tethys. This region was once close to the confluence of the opening Atlantic and Tethys oceans and, therefore, it seems clear that it responded sensitively to changes in global ocean circulation patterns. The area studied is comprised of 
hemipelagic to pelagic environments, which are supposed to be influenced to a minor extent only by land areas. Therefore these areas are still shallow enough to record the changes in sea level and are also distinguished by high sedimentation rates. Two composite sections were measured for the above mentioned study: One from southeastern France (Trescléoux/Oze) and a second from the Swiss Jura (Liesberg).

The lower part in Trescléoux and Oze (southeastern France) belongs to the "Terre Noires" facies and consists of gray to black marls with layers of carbonate nodules. The upper part belongs to the "Argovien" facies (marls with marly limestones). Both sites were sampled at a $1 \mathrm{~m}$ resolution at Trescléoux; 112 samples out of $102 \mathrm{~m}$ at Oze.

However all the prior studies [1-3] lack the information about trace element contents in these sediments. For to this reason the following study was accomplished. The distribution of trace elements in marine sediments provides the necessary information about the seawater chemistry in the past, about weathering and erosion processes and about sudden changes in oceanic circulation as well as about biogeochemical cycles $[4,8-10,18]$. Moreover, marine sediments provide important information on past oceanographic and climatic changes, such as fluctuations in biological productivity, redox state of bottom water, seawater and sediments, tectonic activity, wind strength and volcanic, hydrothermal, hydrogenous, aeolian and fluvial sources [4]. As the changes related to these processes cannot be determined directly, geochemical proxies of climatic and palaeoenvironmental constraints have been developed during the last several decades (e.g. [5-20]).

Bruland [21] provided a detailed and comprehensive review on concentration-depth profiles of trace elements involved in biogeochemical cycles of metal uptake, recycling and particulate deposition. In his study he also addressed the distribution of elements which are either conservative in oxygenated water, are removed from solution by adsorptive scavenging, or are removed by precipitation under anoxic conditions. The most important of his findings was that most trace metals are largely involved in bio-cycling processes In Craig and Miller [22] a comprehensive overview about metal ions and their organometallic compounds in sea water and sediments as well as the related biogeochemical cycles is provided.

In Brumsack and Rinna et al. $[18,23]$ the authors stated that organic-rich sediments are usually enriched in several redox-sensitive elements like $\mathrm{Mo}, \mathrm{V}, \mathrm{Cu}, \mathrm{Zn}$ or $\mathrm{U}$ and stable sulfide-forming trace elements and that they form an important sink in global trace metal cycles. These enrichments must bear a relation to their abundance in seawater (e.g. [24]).

According to Calvert and Pedersen [8] the concentrations of trace and minor elements in marine sediments reflect the range of chemical, oceanographic and sedimentary controls on their supply to, their distribution in and their removal from the ocean. Such controls include the composition of sedimentary detritus delivered to the ocean, the partitioning of individual elements between solid and solution phases, the biogeochemical cycling of the elements in the ocean, the manner in which they are delivered to the sea floor, and the post-depositional conditions in bottom sediments that may lead to diagenetic element recycling or precipitation. As shown in various studies, minor and trace elements behave differently under oxic and anoxic marine conditions and they naturally fall into two categories: 1) Elements whose valency can vary as a function of the actual redox potential: $\mathrm{Mn}, \mathrm{Cr}$, Mo, Re, U, V. These elements occur as highly soluble anionic species in oxic waters but are reduced to insoluble species of lower valency under anoxic conditions [6, 11]. 2) Elements like $\mathrm{Cu}, \mathrm{Ni}, \mathrm{Zn}$ and $\mathrm{Cd}$ are usually removed from solution in the presence of $\mathrm{H}_{2} \mathrm{~S}$ [8]. Pyrite, the most common sulfide in marine sediments prevalently contains $\mathrm{Mn}, \mathrm{Co}, \mathrm{Ni}$ and $\mathrm{Cu}$ as trace elements. Elements as mentioned above are, therefore, of prime use as palaeoproxies. A palaeoproxy record of the climate contains a climatic signal, which can be used to infer qualitative and quantitative information about the past on inter-annual to multi-millenial timescales.

Initially, trace and minor elements are supplied to the site of deposition from terrestrial sources via rivers or the atmosphere, from biological activity within the ocean and from ocean bottom waters. The latter group is commonly called the authigenic fraction of trace and minor elements. Elemental palaeoproxies like $\mathrm{Si}, \mathrm{Fe}, \mathrm{K}, \mathrm{Mg}$, Ti and $\mathrm{Co}$ are of detrital origin, whereas elements like $\mathrm{Ba}, \mathrm{P}, \mathrm{Zn}$ are attributed to be nutrient-related (e.g. [16, 18]). Enhanced concentrations of $\mathrm{Zr}$ and $\mathrm{Nb}$ seem to be of volcanogenic origin [21, 25, 26]. High concentrations of $\mathrm{Ag}$ and $\mathrm{Zn}$ in marine sediments are also assigned to hydrothermal input [4, $18,27,28]$. $\mathrm{Ti}, \mathrm{Zr}$ and $\mathrm{Nb}$ are often concentrated in heavymetal mineral associations, whereas $\mathrm{Ca}$ and $\mathrm{Sr}$ reflect the occurrence of carbonate [29].

Biogenic remnants in marine sediments contain $\mathrm{Si}, \mathrm{Al}$, $\mathrm{Fe}, \mathrm{K}, \mathrm{Ca}, \mathrm{Mg}, \mathrm{Na}, \mathrm{Ti}, \mathrm{Mn}$ and $\mathrm{P} . \mathrm{Zn}, \mathrm{Ni}, \mathrm{Cd}, \mathrm{Cu}$ and $\mathrm{Se}$ are highly enriched in plankton [21]. V, Mn, Fe, Co, Ni, Cu and $\mathrm{Zn}$ play an important role in metal-requiring and metalactivated enzyme systems and protein metabolism in phytoplankton [21] as well as in ancient and in recent bacteria [30].

In Kuhn et al. [31] it is reported that the enrichments of Mn and $\mathrm{Fe}$ in carbonates of Valanginian (Cretaceous) age deposited in the Tethys and Atlantic Oceans, which also show a positive $\partial^{13} \mathrm{C}$ excursion. The correlation of the $\partial^{13} \mathrm{C}$ excursion with trends in $\mathrm{Mn}$ and $\mathrm{Fe}$ contents seems to reflect changes in Valanginian palaeooceanography and climate. High concentrations of $\mathrm{Mn}$ of the early Toarcian, Late Jurassic, Aptian, Albian, Cenomanian/Turonian boundary and Miocene seem to be correlated with ocean-wide anoxia (Oceanic Anoxic Events OAE) and/or changes in the carbon cycle as expressed by positive $\partial^{13} \mathrm{C}$ excursions $[31,32]$. In Bodin et al. [33] an enrichment of redox-sensitive trace elements $(\mathrm{U}, \mathrm{V}, \mathrm{Mo}$, and As) associated with the late Hauterivian (Early Cretaceous) Faraoni oceanic anoxic event was found. There is a certain debate over the latter interrelation. On the contrary, no evidence of an OAE from transects in the western Tethys from the Valaginian period of time (Early Cretaceous) was found [34]. The concentrations of the redox-sensitive elements like U, V, $\mathrm{Co}$ and Mo were not as enriched as expected for reductive bottom-water conditions within the respective transects. The enhanced concentration of $\mathrm{Mn}$ was attributed to an increase in continental influx, combined with higher Mn redox-recycling. 
They conclude that anoxic events were rather limited to marginal seas.

The goals in this paper are to present the chemical analyses and the determination of 36 trace elements in the Oxfordian marine sediments from two localities in southern France. The correlation of these trace element contents with the two positive $\partial^{13} \mathrm{C}$ excursions and their use as palaeoproxies will be discussed. The unambiguous, broad and unique correlation of these trace elements to oceanographic and climatic changes - such as fluctuations in biological productivity, redox state of bottom water, seawater and sediments, tectonic activity, wind strength as well as volcanic, hydrothermal, hydrogenous, aeolian and fluvial sources - will be illustrated.

\section{STUDY SITE AND SAMPLE MATERIAL}

The studied composite section, exposed near Serres (SEFrance), was deposited in the Tethyan Subalpine basin, a deep epeiric basin influenced by tectonics related to the opening of the Alpine Tethys and the Atlantic (Fig. 1).

Two separate sections were analyzed, outcropping at a distance of about 500 meters from each other. Sampling was performed at $1 \mathrm{~m}$-resolution. The lower part is exposed on a hill slope adjacent to the village of Trescléoux. It belongs to the "Terre Noires" facies and consists of grey to black marls, which contain layers of carbonate nodules parallel to the bedding. These nodules are round to oval in shape, and about three to ten centimeters in diameter [1]. Up-section, nodules become more abundant. The upper part of the section comprises the "Argovien" facies. This facies consists of an alternation of marls with marly limestones. The base of the "Argovien" is very distinct in the field, thus providing a good correlation marker. The "Argovien" facies replaces the "Terre Noires" synchronously in the whole Subalpine basin, marking the top part of the Antecedens ammonite-subzone. Here another 94 samples were collected within 80 meters [1].

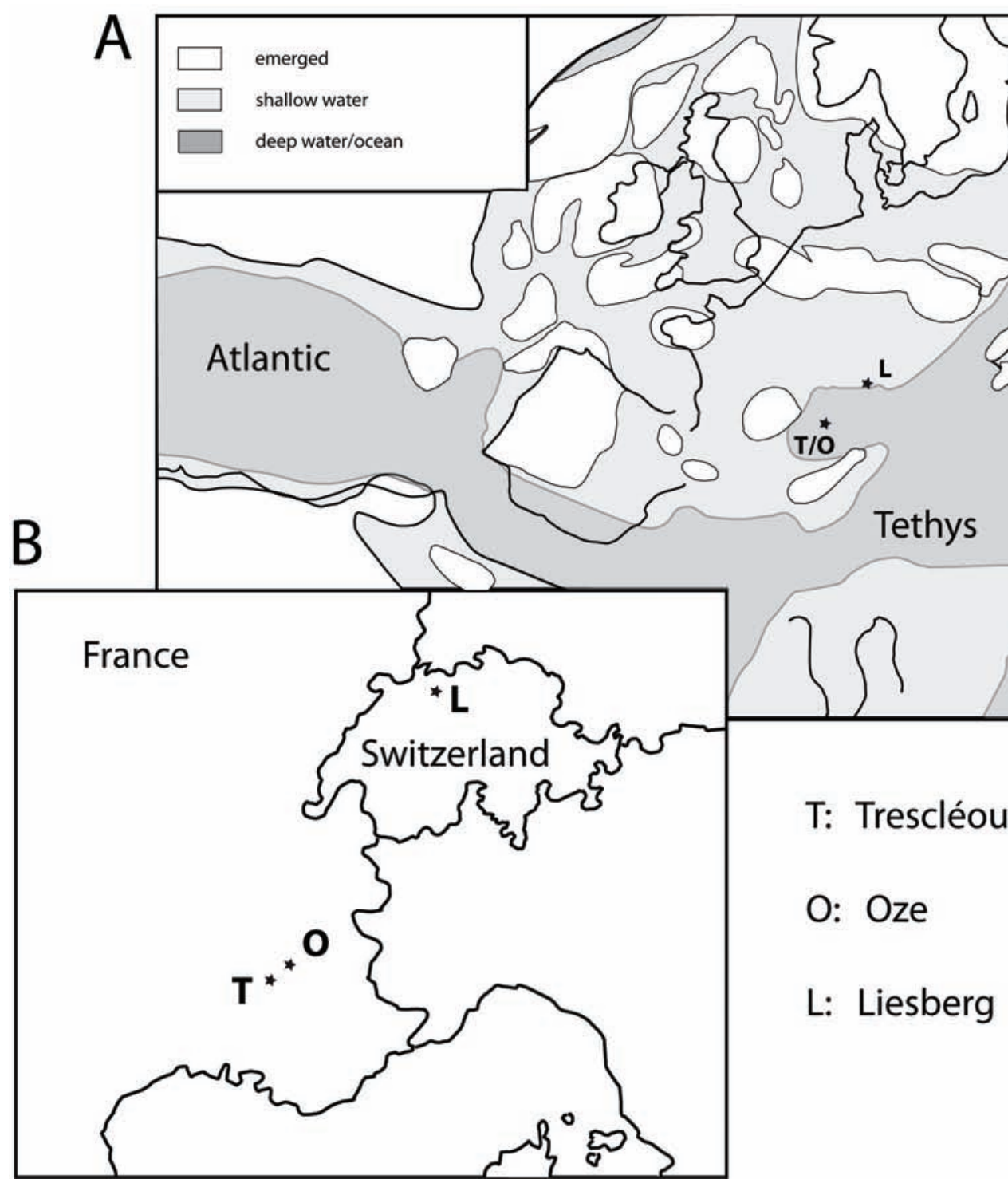

Fig. (1). Location map (A) and paleogeography (B) of the studied sections. $T=$ Trescléoux, $O=$ Oze. Black lines represent modern coast lines and state borders. Palaeomap modified after [77]. Location map after Louis-Schmid et al. [2]. 
Oze is situated around $50 \mathrm{~km}$ to the northeast of Trescléoux. Samples were taken from the top of the Vertebrale and the whole Antecedens ammonite subzone. This section is the direct stratigraphic precursor of the "Argovien" facies and could not be clearly identified and, therefore, not sampled at Trescléoux. The facies is the same as in the lower part of Trescléoux, except that the nodules are slightly bigger. 112 samples within a height of 102 meters were collected. Correlation between Trescléoux and Oze is specified by a remarkably thick bentonite layer occurring in the Vertebrale ammonite subzone.

The lower "Terre Noires" facies consists of dark, clayey marlstones with carbonate contents commonly between 30 and $40 \mathrm{wt} . \%$. The carbonate consists of calcite dominated by micrite, but well-preserved coccoliths and parts of coccospheres are also present. Protoglobigerines can be observed as well. Macrofossils are rare but dominated by ammonites and belemnites. Carbonate nodules, with up to $80 \% \mathrm{CaCO} 3$, are frequent in the "Terre Noires" and the Sornetan Member. They reach up to 30 centimeters in diameter. The "Terre Noires" also have slightly elevated organic carbon contents (up to $0.8 \%$ in the "Terre Noires"). In the upper part of the "Terre Noires", limestone becomes dominant $[1,2]$.

The "Argovien" facies is carbonate-rich, ranging between 50 and 90 wt.\% $\mathrm{CaCO}_{3}$, and forms an alternation of marlstones and limestones. Organic matter is a mixture of mainly marine and sparse terrestrial material based on biomarker evidence.

Detrital minerals include clays and quartz, carbonate includes micrite, coccoliths and foraminifera; macrofossils are rare and consist mainly of ammonites and belemnites. The marlstones are bedded at a decimeter- to meter-scale (according [1 - 3]).

\section{EXPERIMENTAL}

\section{Sample Preparation}

21 samples consisting of the so called "Terre Noires" from Oze (grey to black marlstone with carbonate nodules parallel to the bedding) and 8 samples from Trescléoux (grey to black marlstone with carbonate nodules parallel to the bedding in the lower part and an alteration of marlstones and limestones of the so called "Argovien" in the upper part) were treated as follows:

Fused glasses were prepared by mixing a 5:1 ratio of flux to a finely ground sample (approx. $1.5 \mathrm{~g}$, after milling $30 \mathrm{~g}$ of a sample down to fine grains). After determination of the loss of ignition and careful homogenization the samples were transferred to $\mathrm{Pt}$ crucibles and melted at $1100^{\circ} \mathrm{C}$ in a top loading furnace (Claisse M4 Fluxer from Corporation Scientifique Claisse, Sainte-Foy, Québec, Canada) for 15 minutes. Automatic agitation ensured a good homogeneity of the melt. The melt was automatically poured into Pt plates and air cooled.

\section{Laser Ablation Analysis}

A pulsed $193 \mathrm{~nm}$ ArF Excimer laser (Lambda Physik, Germany) with a homogeneous beam delivery prototype system similar to a Geolas (Microlas, Germany) in combination with an ELAN 6100 DRC (Perkin Elmer,
Canada) ICP-MS was used to perform the LA-ICP-MS analyses of major, minor and trace elements $[35,36]$. Up to ten samples were loaded along with the glass standard NIST 610 in a $15 \mathrm{~cm}^{3}$ ablation cell and put on the stage of a modified petrographic microscope. To the laser ablation carrier gas, helium, the make up gas argon was admixed after the ablation cell and the aerosol then carried to ICP-MS. Following methods as described by [37] and [38] data reduction was carried out using the software LAMTRACE and in-house spreadsheets. Limits of detection were calculated for each element and each analysis individually as three times the standard deviation of the background signal (measured before laser ablation) divided by element sensitivity during the respective ablation. More details of the laser ablation analyses can be found in [39].

\section{RESULTS}

All samples were measured for the following elements: $\mathrm{Na}, \mathrm{Mg}, \mathrm{Al}, \mathrm{Si}, \mathrm{P}, \mathrm{K}, \mathrm{Sc}, \mathrm{Ti}, \mathrm{V}, \mathrm{Cr}, \mathrm{Mn}, \mathrm{Fe}, \mathrm{Co}, \mathrm{Ni}, \mathrm{Cu}, \mathrm{Zn}$, $\mathrm{As}, \mathrm{Rb}, \mathrm{Sr}, \mathrm{Y}, \mathrm{Zr}, \mathrm{Nb}, \mathrm{Mo}, \mathrm{Ag}, \mathrm{Cd}, \mathrm{Sn}, \mathrm{Sb}, \mathrm{Cs}, \mathrm{Ba}, \mathrm{La}, \mathrm{Ce}$, $\mathrm{W}, \mathrm{Tl}, \mathrm{Pb}, \mathrm{Bi}, \mathrm{U}$. The concentration of As is rarely above the LOD (limit of detection. Sb and Tl were often not above the $\mathrm{LOD}, \mathrm{Mo}, \mathrm{Ag}$ and $\mathrm{Cd}$ are not considered any further, as their concentration is constantly below LOD. Table $\mathbf{1}$ lists all the concentrations and the standard deviation of the relevant elements and Fig. (3) illustrates examples of concentration patterns.

Studies $[1,2]$ report a $\partial^{13} \mathrm{C}$ excursion in the "Argovien" facies (marls with marly limestone) from Trescléoux where samples were taken within the upper section for this study (Fig. 2). Within the lowest sequence of Trescléoux a continuous rise of the $\partial^{13} \mathrm{C}$-values from about 0 to $2 \%$ is evident. After an interim decrease to values around $1 \%$, $\partial^{13} \mathrm{C}$-values oscillate around $1.5 \%$. The positive excursion in the strict sense then starts from values at around $2 \%$ and reaches values of more than $3 \%$ at its maximum. The most positive values are almost immediately followed by a negative spike down to around $0.5 \%$. Later values of around 2 to $2.5 \%$ are reached again. The most pronounced change in lithology, from the "Terre Noires" to the "Argovien", takes place as the values of $\partial^{13} \mathrm{C}$ rise from 2 to $3 \%$.

For the present study a representative portion of samples available from Trescléoux and Oze were used for the analysis of major, minor and trace elements. The samples were chosen in order to represent all sections of the profile according to the portions with the most pronounced changes in $\partial^{13} \mathrm{C}[1]$.

The fluctuation or variation in concentration of the chemical elements in question are of major interest within the positive excursion in the strictest sense with a $\partial^{13} \mathrm{C}$ rise from 2 to $3 \%$. The major elements $\mathrm{Na}, \mathrm{Mg}$ and $\mathrm{Al}$ (Fig. 3 with $\mathrm{Na}, \mathrm{Mg}$ and $\mathrm{Al}$ as examples) reach the highest concentrations within the excursion just before their concentrations decreases again to values as measured within the lower zones. Si and $\mathrm{K}$ do not show this clear rise in concentration within the $\partial^{13} \mathrm{C}$ excursion, but again exhibit the decrease within the zone of the negative spike down to around $0.5 \%$. The fluctuation in concentrations of Si and $\mathrm{K}$ within the lower part of the "Terre Noires" are similar to those of $\mathrm{Na}, \mathrm{Mg}$ and $\mathrm{Al}$. 
Table 1a. Element Concentrations in ppm with Standard Deviations in Marine Sediments as Measured by LA-ICP-MS (Three Analyses Per Average)

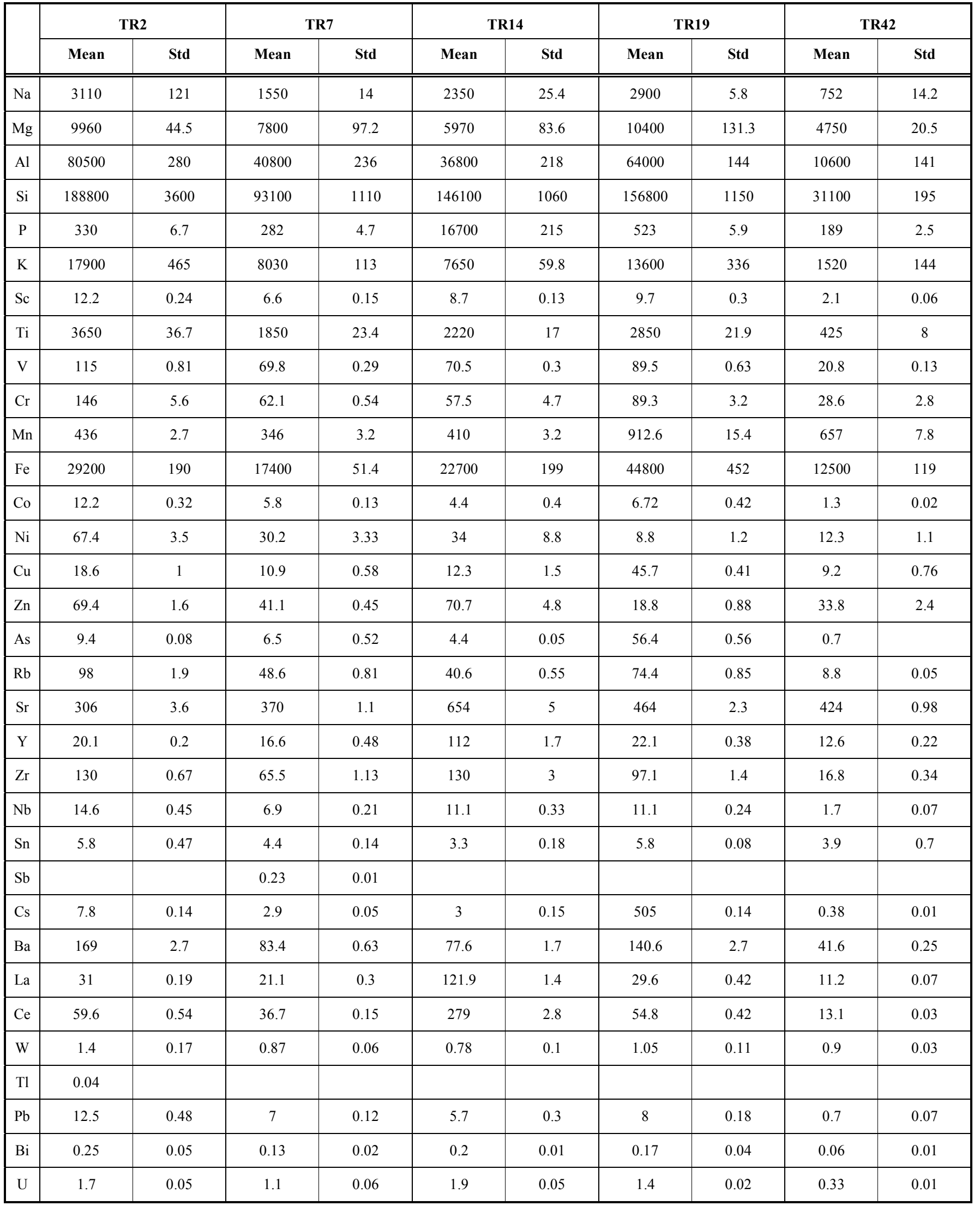


Table 1b. Average Shale in ppm, Element/Al Ratios and Element Concentrations in ppm with Standard Deviations in Marine Sediments as Measured by LA-ICP-MS (Three Analyses Per Average)

\begin{tabular}{|c|c|c|c|c|c|c|c|c|c|c|}
\hline & \multicolumn{2}{|c|}{ OZ5 } & \multicolumn{2}{|c|}{ OZ15 } & \multicolumn{2}{|c|}{ OZ25 } & \multicolumn{2}{|c|}{ OZ34 } & \multicolumn{2}{|c|}{ OZ239 } \\
\hline $\mathrm{Mg}$ & 6830 & 76.6 & 5970 & 83.6 & 7730 & 100 & 5980 & 74.1 & 6280 & 80.9 \\
\hline $\mathrm{Al}$ & 57200 & 407 & 36800 & 218 & 41200 & 328 & 49500 & 335 & 26400 & 426 \\
\hline $\mathrm{P}$ & 154 & 12.2 & 16700 & 215 & 230 & 4.4 & 305 & 4.4 & 169 & 4.3 \\
\hline K & 11600 & 144 & 7650 & 59.8 & 8420 & 148 & 11000 & 56 & 4670 & 29.2 \\
\hline $\mathrm{Sc}$ & 9.4 & 0.62 & 8.7 & 0.13 & 8.4 & 0.69 & 9 & 0.61 & 5.3 & 0.3 \\
\hline $\mathrm{Mn}$ & 309 & 4.8 & 410 & 3.2 & 708 & 13 & 236 & 5.7 & 310 & 1.6 \\
\hline $\mathrm{Fe}$ & 25600 & 487 & 22700 & 199 & 66200 & 733 & 24000 & 76.9 & 13800 & 263 \\
\hline Co & 8.8 & 0.12 & 4.4 & 0.4 & 5.4 & 0.31 & 7.7 & 0.18 & 1.9 & 0.14 \\
\hline $\mathrm{Ni}$ & 51.7 & 4.5 & 34 & 8.8 & 43.9 & 2.7 & 44.5 & 2.1 & 19.5 & 0.7 \\
\hline $\mathrm{Cu}$ & 20.3 & 0.88 & 12.3 & 1.5 & 15.9 & 4.9 & 16.8 & 1.2 & 11.8 & 0.57 \\
\hline $\mathrm{Zn}$ & 72.3 & 3.7 & 70.7 & 4.8 & 67.4 & 3.1 & 58.4 & 1.4 & 38.9 & 2.4 \\
\hline $\mathrm{Nb}$ & 13.2 & 0.1 & 11.1 & 0.33 & 10.1 & 0.29 & 11.5 & 0.18 & 4.8 & 0.12 \\
\hline $\mathrm{Sn}$ & 4.4 & 0.33 & 3.3 & 0.18 & 7.2 & 0.05 & 7.5 & 0.47 & 4.3 & 0.42 \\
\hline $\mathrm{Sb}$ & & & & & & & 0.34 & 0.06 & & \\
\hline $\mathrm{Cs}$ & 4.8 & 0.11 & 3 & 0.15 & 3.7 & 0.12 & 4.6 & 0.08 & 0.47 & 0.27 \\
\hline $\mathrm{Ba}$ & 128 & 1.71 & 77.6 & 1.7 & 89.7 & 0.68 & 120 & 0.75 & 51.1 & 0.39 \\
\hline $\mathrm{La}$ & 25.5 & 0.13 & 121.9 & 1.4 & 20.6 & 0.32 & 27.2 & 0.11 & 19 & 0.18 \\
\hline $\mathrm{Ce}$ & 47.2 & 0.27 & 279 & 2.8 & 37.3 & 0.22 & 48.1 & 0.65 & 27.9 & 0.2 \\
\hline W & 1.2 & 0.07 & 0.78 & 0.1 & 0.9 & 0.12 & 0.91 & 0.04 & 0.63 & 0.06 \\
\hline $\mathrm{Tl}$ & 0.02 & & & & 0.03 & & 0.01 & 0.001 & 0.01 & \\
\hline $\mathrm{Pb}$ & 11.2 & 0.65 & 5.7 & 0.3 & 8.7 & 0.034 & 10.6 & 0.19 & 3.8 & 0.26 \\
\hline $\mathrm{Bi}$ & 0.16 & 0.01 & 0.2 & 0.01 & 0.16 & 0.01 & 0.15 & 0.05 & 0.1 & 0.1 \\
\hline $\mathrm{U}$ & 1.5 & 0.05 & 1.9 & 0.05 & 1.1 & 0.03 & 1.46 & 0.07 & 0.86 & 0.07 \\
\hline
\end{tabular}


Table 1c. Average Shale in ppm, Element/Al Ratios and Element Concentrations in ppm with Standard Deviations in Marine Sediments as Measured by LA-ICP-MS (Three Analyses Per Average)

\begin{tabular}{|c|c|c|c|c|c|c|c|c|c|c|}
\hline & \multicolumn{2}{|c|}{ OZ265 } & \multicolumn{2}{|c|}{ OZ272 } & \multicolumn{2}{|c|}{ OZ279 } & \multicolumn{2}{|c|}{ OZ285 } & \multicolumn{2}{|c|}{ OZ289 } \\
\hline & Mean & Std & Mean & Std & Mean & Std & Mean & Std & Mean & Std \\
\hline $\mathrm{Na}$ & 2430 & 14.9 & 2200 & 21.2 & 2400 & 44.3 & 2270 & 27.8 & 2150 & 42.8 \\
\hline $\mathrm{Mg}$ & 7350 & 61.3 & 7300 & 117.5 & 9600 & 141 & 7490 & 94.3 & 6780 & 21.5 \\
\hline $\mathrm{Al}$ & 58800 & 487 & 59500 & 908 & 54800 & 576 & 58290 & 219 & 60500 & 655 \\
\hline $\mathrm{Si}$ & 195100 & 1660 & 176000 & 4190 & 159000 & 4465 & 180100 & 2500 & 179000 & 3180 \\
\hline $\mathrm{P}$ & 288 & 19.8 & 155 & 6.4 & 352 & 14.8 & 184 & 6.7 & 216 & 8.9 \\
\hline $\mathrm{K}$ & 13100 & 51.1 & 12500 & 191 & 12675 & 219 & 15680 & 253 & 16300 & 141 \\
\hline $\mathrm{Sc}$ & 10.8 & 0.69 & 8.7 & 0.21 & 11.3 & 0.74 & 9.7 & 0.35 & 11 & 0.35 \\
\hline $\mathrm{Ti}$ & 3480 & 9.6 & 3050 & 28.6 & 3290 & 9.8 & 3160 & 68.9 & 3060 & 11.6 \\
\hline $\mathrm{V}$ & 98.2 & 1 & 93.8 & 2.6 & 96.2 & 1.8 & 97.4 & 1.8 & 104 & 1.3 \\
\hline $\mathrm{Cr}$ & 80 & 5.9 & 115 & 6.6 & 82.4 & 5.5 & 123 & 2 & 116 & 6.3 \\
\hline $\mathrm{Mn}$ & 214 & 1.2 & 214 & 2.4 & 252 & 4 & 253 & 2.2 & 236 & 3.3 \\
\hline $\mathrm{Fe}$ & 27400 & 182 & 22700 & 292 & 27100 & 516 & 26500 & 370 & 25000 & 290 \\
\hline Co & 6.7 & 0.19 & 6.9 & 0.22 & 8.3 & 0.13 & 9.1 & 0.26 & 8 & 0.32 \\
\hline $\mathrm{Ni}$ & 48.8 & 8.2 & 39.5 & 2.98 & 41.7 & 5.4 & 51.3 & 3.7 & 36.9 & 4.3 \\
\hline $\mathrm{Cu}$ & 15.9 & 0.71 & 21.7 & 0.23 & 14.9 & 0.9 & 13.1 & 0.86 & 19.2 & 2 \\
\hline $\mathrm{Zn}$ & 55.1 & 1.22 & 90.8 & 1.4 & 51.2 & 1.4 & 65.6 & 0.91 & 95.3 & 3.1 \\
\hline As & 5 & 0.45 & 4.2 & 0.65 & 2.9 & 0.8 & 4.2 & 0.61 & 3.4 & 0.4 \\
\hline $\mathrm{Rb}$ & 73.7 & 1.56 & 78.9 & 0.86 & 72.8 & 1.7 & 84.4 & 0.35 & 95 & 1.7 \\
\hline $\mathrm{Sr}$ & 338 & 0.71 & 395 & 1.46 & 446 & 1.4 & 417 & 6.1 & 314 & 1.5 \\
\hline $\mathrm{Y}$ & 18.2 & 0.38 & 16.2 & 0.75 & 21.5 & 0.81 & 18.4 & 0.32 & 16.7 & 0.77 \\
\hline $\mathrm{Zr}$ & 147 & 1.22 & 104 & 3.11 & 152 & 3.5 & 127 & 0.66 & 105 & 2.1 \\
\hline $\mathrm{Nb}$ & 18.6 & 0.36 & 12.9 & 0.07 & 14.6 & 0.05 & 12.6 & 0.11 & 12.5 & 0.47 \\
\hline $\mathrm{Sn}$ & 3.8 & 0.85 & 7.3 & 0.73 & 4.2 & 0.34 & 8.1 & 0.86 & 8.5 & 0.13 \\
\hline $\mathrm{Sb}$ & 0.7 & 0.15 & 0.35 & & & & & & & \\
\hline Cs & 5.9 & 0.26 & 6.0 & 0.11 & 5.6 & 0.19 & 6.2 & 0.04 & 7 & 0.16 \\
\hline $\mathrm{Ba}$ & 127 & 1.2 & 136 & 1.7 & 142 & 2.7 & 153 & 2.9 & 163 & 1.69 \\
\hline $\mathrm{La}$ & 26.4 & 0.41 & 26 & 0.45 & 30.4 & 0.3 & 28.8 & 0.26 & 27 & 0.6 \\
\hline $\mathrm{Ce}$ & 46.1 & 0.42 & 43.7 & 0.93 & 51.7 & 1.2 & 49.3 & 0.83 & 46.7 & 0.21 \\
\hline W & 1.3 & 0.18 & 1.2 & 0.16 & 1.2 & 0.15 & 1.2 & 0.09 & 1.4 & 0.19 \\
\hline $\mathrm{Tl}$ & 0.14 & 0.06 & 0.01 & & 0.07 & 0.01 & 0.01 & & & \\
\hline $\mathrm{Pb}$ & 10.4 & 0.34 & 9 & 0.56 & 9 & 0.23 & 13.3 & 0.13 & 10.3 & 0.55 \\
\hline $\mathrm{Bi}$ & 0.24 & 0.03 & 0.2 & 0.01 & 0.22 & 0.06 & 0.18 & 0.02 & 0.24 & 0.6 \\
\hline $\mathrm{U}$ & 1.6 & 0.07 & 1.5 & 0.02 & 1.7 & 0.03 & 1.39 & 0.03 & 1.5 & 0.01 \\
\hline
\end{tabular}


Table 1d. Average Shale in ppm, Element/Al Ratios and element Concentrations in ppm with Standard Deviations in Marine Sediments as Measured by LA-ICP-MS (Three Analyses Per Average)

\begin{tabular}{|c|c|c|c|c|c|c|c|c|c|c|}
\hline & \multicolumn{2}{|c|}{ OZ294 } & \multicolumn{2}{|c|}{ OZ300 } & \multicolumn{2}{|c|}{ OZ301 } & \multicolumn{2}{|c|}{ OZ306 } & \multicolumn{2}{|c|}{ OZ310 } \\
\hline & Mean & Std & Mean & Std & Mean & Std & Mean & Std & Mean & Std \\
\hline $\mathrm{Na}$ & 1930 & 12.2 & 2200 & 21.6 & 2000 & 18 & 1660 & 38.4 & 1810 & 18.1 \\
\hline $\mathrm{Mg}$ & 5940 & 55.2 & 5800 & 63 & 6180 & 85.5 & 6480 & 89.8 & 7040 & 91.7 \\
\hline $\mathrm{Al}$ & 50500 & 578 & 45300 & 365 & 39200 & 217 & 51800 & 103 & 47500 & 307 \\
\hline $\mathrm{Si}$ & 170000 & 2740 & 178100 & 3580 & 154000 & 2630 & 182000 & 4810 & 166900 & 1340 \\
\hline $\mathrm{P}$ & 224 & 10.5 & 304 & 15.5 & 207 & 7.1 & 154 & 8.1 & 158 & 4.2 \\
\hline $\mathrm{K}$ & 13200 & 206 & 10500 & 90.5 & 9170 & 92.9 & 13500 & 234 & 9920 & 153 \\
\hline $\mathrm{Sc}$ & 9 & 0.31 & 8.7 & 0.88 & 7.3 & 0.5 & 9 & 0.3 & 8.5 & 0.3 \\
\hline $\mathrm{Ti}$ & 2730 & 40.8 & 2810 & 24.7 & 2120 & 7.2 & 2620 & 46.1 & 2610 & 12.7 \\
\hline $\mathrm{V}$ & 94 & 1.2 & 89.3 & 1.6 & 75.4 & 1.7 & 90.9 & 2.6 & 88.6 & 1 \\
\hline $\mathrm{Cr}$ & 111 & 4.8 & 67.7 & 1.9 & 61 & 1.6 & 124 & 10.6 & 101 & 1.4 \\
\hline $\mathrm{Mn}$ & 180 & 3.3 & 139 & 1.9 & 204 & 2 & 165 & 1.8 & 202 & 4 \\
\hline $\mathrm{Fe}$ & 21500 & 386 & 21800 & 218 & 20100 & 313 & 21000 & 544 & 20400 & 178 \\
\hline Co & 8.4 & 0.23 & 7.6 & 0.22 & 5 & 0.3 & 4.8 & 0.09 & 4.4 & 0.4 \\
\hline $\mathrm{Ni}$ & 46.6 & 11.3 & 40.6 & 2.2 & 32.3 & 9.1 & 42.2 & 2.3 & 32.5 & 3.3 \\
\hline $\mathrm{Cu}$ & 14.4 & 1.2 & 12.7 & 0.5 & 11.1 & 0.8 & 16.1 & 1 & 13.1 & 2.4 \\
\hline $\mathrm{Zn}$ & 99.6 & 1.5 & 51.2 & 2.2 & 40.4 & 2.4 & 80.8 & 3.3 & 62 & 2.3 \\
\hline As & 4 & 0.17 & 4.9 & 0.1 & 3.2 & 0.59 & 3.9 & 0.39 & 3.2 & 0.34 \\
\hline $\mathrm{Rb}$ & 73.1 & 0.9 & 59.4 & 1.5 & 51.4 & 0.86 & 74.3 & 1.1 & 65.4 & 0.9 \\
\hline $\mathrm{Sr}$ & 386 & 7.3 & 353 & 1.8 & 402 & 3.6 & 313 & 4.9 & 377 & 2.9 \\
\hline $\mathrm{Y}$ & 19.5 & 0.15 & 17.8 & 0.59 & 16.5 & 0.26 & 16.5 & 0.44 & 17 & 0.31 \\
\hline $\mathrm{Zr}$ & 111 & 2.8 & 122 & 2.8 & 106 & 1.4 & 97.1 & 0.79 & 115 & 1.8 \\
\hline $\mathrm{Nb}$ & 12 & 0.19 & 13.6 & 0.39 & 11.4 & 0.05 & 11.4 & 0.04 & 10.5 & 0.32 \\
\hline $\mathrm{Sn}$ & 8.2 & 0.56 & 3.6 & 0.48 & 3.5 & 0.05 & 7.8 & 0.17 & 7.8 & 0.37 \\
\hline $\mathrm{Sb}$ & 0.5 & 0.03 & & & 0.54 & & & & & \\
\hline Cs & 5.6 & 0.2 & 4.7 & 0.07 & 4 & 0.26 & 5.9 & 0.18 & 5.4 & 0.5 \\
\hline $\mathrm{Ba}$ & 167 & 1.57 & 604 & 5.5 & 123 & 1.7 & 121.3 & 2.5 & 105 & 1.3 \\
\hline $\mathrm{La}$ & 27.6 & 0.22 & 24.1 & 0.6 & 23.3 & 0.37 & 23 & 0.4 & 23.2 & 0.41 \\
\hline $\mathrm{Ce}$ & 43.6 & 0.82 & 41.2 & 0.85 & 37.2 & 0.7 & 37.5 & 0.9 & 38.3 & 0.55 \\
\hline W & 1 & 0.06 & 1.1 & 0.17 & 0.84 & 0.13 & 1.4 & 0.07 & 1.15 & 0.16 \\
\hline $\mathrm{Tl}$ & 0.026 & & 0.1 & 0.02 & & & & & 0.02 & 0.006 \\
\hline $\mathrm{Pb}$ & 8.1 & 0.22 & 0.7 & 0.22 & 6.6 & 0.23 & 8.8 & 0.41 & 8.5 & 0.43 \\
\hline $\mathrm{Bi}$ & 0.2 & 0.05 & 0.1 & 0.03 & 0.19 & 0.04 & 0.16 & 0.15 & 0.16 & 0.01 \\
\hline $\mathrm{U}$ & 1.4 & 0.03 & 7.7 & 0.09 & 1.25 & 0.05 & 1.27 & 0.05 & 1.2 & 0.05 \\
\hline
\end{tabular}


Table 1e. Average Shale in ppm, Element/Al Ratios and Element Concentrations in ppm with Standard Deviations in Marine Sediments as Measured by LA-ICP-MS (Three Analyses Per Average)

\begin{tabular}{|c|c|c|c|c|c|c|c|c|c|c|}
\hline & \multicolumn{2}{|c|}{ OZ314 } & \multicolumn{2}{|c|}{ OZ318 } & \multicolumn{2}{|c|}{ OZ328 } & \multicolumn{2}{|c|}{ OZ330 } & \multicolumn{2}{|c|}{ OZ331 } \\
\hline & Mean & Std & Mean & Std & Mean & Std & Mean & Std & Mean & Std \\
\hline $\mathrm{Na}$ & 1630 & 19 & 1390 & 13.4 & 1180 & 324 & 1500 & 9 & 946 & 14 \\
\hline $\mathrm{Mg}$ & 6540 & 66.3 & 5710 & 28.6 & 8560 & 152 & 8870 & 38.3 & 5940 & 30.6 \\
\hline $\mathrm{Al}$ & 48500 & 428 & 38200 & 323 & 39900 & 318 & 39900 & 297 & 20500 & 127 \\
\hline $\mathrm{Si}$ & 162200 & 761 & 116700 & 1220 & 147600 & 4740 & 117400 & 2230 & 64600 & 93.3 \\
\hline $\mathrm{P}$ & 316 & 8 & 217 & 1.7 & 167 & 5.2 & 292 & 5.8 & 395 & 6.8 \\
\hline K & 10160 & 68.2 & 8530 & 90.3 & 8820 & 60.2 & 8410 & 66.5 & 2890 & 21.5 \\
\hline $\mathrm{Sc}$ & 8.5 & 0.29 & 6.5 & 0.1 & 7.2 & 0.44 & 7.2 & 0.26 & 3.8 & 0.2 \\
\hline $\mathrm{Ti}$ & 2470 & 17 & 2010 & 34.4 & 1970 & 19 & 2000 & 36.8 & 976 & 6.5 \\
\hline $\mathrm{V}$ & 84 & 1.1 & 68.4 & 0.79 & 78.8 & 1.2 & 79.9 & 0.55 & 44.6 & 0.34 \\
\hline $\mathrm{Cr}$ & 80.1 & 5.1 & 54.6 & 0.56 & 94.3 & 8.1 & 81.8 & 1.5 & 46.4 & 1.5 \\
\hline $\mathrm{Mn}$ & 184 & 0.31 & 197 & 3 & 210 & 1.4 & 241 & 2.2 & 412 & 5.1 \\
\hline $\mathrm{Fe}$ & 21400 & 178 & 17800 & 224 & 20800 & 261 & 16300 & 249 & 11500 & 158 \\
\hline Co & 6 & 0.3 & 2.9 & 0.04 & 4.4 & 0.2 & 4.8 & 0.58 & 4.6 & 0.2 \\
\hline $\mathrm{Ni}$ & 38.9 & 3.4 & 24.3 & 1.2 & 30.6 & 1.9 & 30.4 & 3.8 & 15.8 & 2.9 \\
\hline $\mathrm{Cu}$ & 17.3 & 3.4 & 11.2 & 0.63 & 15 & 1 & 14.7 & 0.3 & 9.8 & 2.1 \\
\hline $\mathrm{Zn}$ & 71.2 & 2.7 & 31.6 & 2.5 & 55.4 & 2.4 & 48.3 & 2.1 & 34.8 & 2.5 \\
\hline As & 4 & 0.25 & 2 & 0.24 & 2.6 & 0.9 & 3.3 & 0.29 & 2.9 & 0.6 \\
\hline $\mathrm{Rb}$ & 61.7 & 0.51 & 52.1 & 0.99 & 53.6 & 0.17 & 51.1 & 0.08 & 14.2 & 0.15 \\
\hline $\mathrm{Sr}$ & 346 & 2.5 & 332 & 4.38 & 430 & 2.4 & 499 & 3.7 & 514 & 2.9 \\
\hline $\mathrm{Y}$ & 20.4 & 0.14 & 15.9 & 0.2 & 14.1 & 0.33 & 16.3 & 0.66 & 14 & 0.16 \\
\hline $\mathrm{Zr}$ & 104 & 2.8 & 68.8 & 0.42 & 82 & 1.8 & 75.3 & 1.3 & 39.5 & 0.08 \\
\hline $\mathrm{Nb}$ & 10.5 & 0.22 & 7.8 & 0.19 & 7.6 & 0.23 & 6.9 & 0.42 & 3.6 & 0.1 \\
\hline $\mathrm{Sn}$ & 4.7 & 0.5 & 4.8 & 0.48 & 8.1 & 1.5 & 7.5 & 0.05 & 4.0 & 0.21 \\
\hline $\mathrm{Sb}$ & 0.27 & 0.03 & & & & & 0.5 & & & \\
\hline Cs & 5 & 0.01 & 3.9 & 0.11 & 4.2 & 0.43 & 3.7 & 0.13 & 0.34 & 0.02 \\
\hline $\mathrm{Ba}$ & 102 & 1 & 75.9 & 0.82 & 80.7 & 0.8 & 81.1 & 0.72 & 41.8 & 0.22 \\
\hline $\mathrm{La}$ & 26.1 & 0.3 & 22 & 0.15 & 19.6 & 0.46 & 21.5 & 0.44 & 15 & 0.2 \\
\hline $\mathrm{Ce}$ & 42.4 & 0.89 & 33.3 & 0.43 & 32.7 & 0.06 & 35.8 & 0.66 & 23.2 & 0.35 \\
\hline W & 1 & 0.11 & 1.3 & 0.1 & 1.4 & 0.98 & 0.82 & 0.11 & 0.52 & 0.12 \\
\hline $\mathrm{Tl}$ & & & 0.02 & & 0.08 & & & & 0.01 & \\
\hline $\mathrm{Pb}$ & 8 & 0.25 & 6 & 0.18 & 6.96 & 0.66 & 5.7 & 0.14 & 1.9 & 0.17 \\
\hline $\mathrm{Bi}$ & 0.1 & 0.03 & 0.15 & 0.02 & 0.67 & 0.09 & 0.15 & 0.03 & 0.09 & 0.02 \\
\hline $\mathrm{U}$ & 1.3 & 0.04 & 1.2 & 0.07 & 1.7 & 0.06 & 1.04 & 0.04 & 0.67 & 0.03 \\
\hline
\end{tabular}


Table 1f. Average Shale in ppm, Element/Al Ratios and Element Concentrations in ppm with Standard Deviations in Marine Sediments as Measured by LA-ICP-MS (Three Analyses Per Average)

\begin{tabular}{|c|c|c|c|c|c|c|c|c|c|c|}
\hline & \multicolumn{2}{|c|}{ OZ332 } & \multicolumn{2}{|c|}{ TRE21.5 } & \multicolumn{2}{|c|}{ TRE32 } & \multicolumn{2}{|c|}{ TRE44 } & \multicolumn{2}{|c|}{ TRE72 } \\
\hline & Mean & Std & Mean & Std & Mean & Std & Mean & Std & Mean & Std \\
\hline $\mathrm{Na}$ & 1170 & 17.8 & 3780 & 73.5 & 1160 & 501 & 2970 & 7 & 2550 & 16.9 \\
\hline $\mathrm{Mg}$ & 6760 & 39.5 & 16700 & 61 & 1490 & 36.5 & 7380 & 30.5 & 7100 & 38.5 \\
\hline $\mathrm{Al}$ & 28100 & 439 & 61400 & 312 & 1270 & 184.4 & 58700 & 223 & 61400 & 459 \\
\hline $\mathrm{Si}$ & 83200 & 1680 & 167000 & 3050 & 5830 & 1680 & 176000 & 1590 & 163500 & 2050 \\
\hline $\mathrm{P}$ & 1686 & 7 & 2240 & 13.9 & 174 & 47.6 & 361 & 1.5 & 167 & 5 \\
\hline $\mathrm{K}$ & 5680 & 38 & 6260 & 25.6 & 854 & 462 & 13100 & 87.7 & 15000 & 63.4 \\
\hline $\mathrm{Sc}$ & 6.1 & 0.25 & 11.1 & 0.5 & 0.51 & 0.04 & 9.8 & 0.48 & 10.1 & 0.22 \\
\hline $\mathrm{Ti}$ & 1340 & 12.5 & 2700 & 73.7 & 12600 & 452 & 3120 & 9.2 & 3170 & 11.8 \\
\hline $\mathrm{V}$ & 55.4 & 1.2 & 116.9 & 2.5 & 3 & 1.6 & 89.4 & 0.37 & 103 & 1.1 \\
\hline $\mathrm{Cr}$ & 64.3 & 4.6 & 92.4 & 3.2 & 6.6 & 2.7 & 75 & 11 & 77.5 & 3.3 \\
\hline $\mathrm{Mn}$ & 358 & 5.7 & 2600 & 20.4 & 210 & 8.2 & 473 & 6 & 591 & 6.6 \\
\hline $\mathrm{Fe}$ & 16600 & 56.9 & 36700 & 182 & 520 & 93.7 & 25700 & 146 & 32700 & 281.7 \\
\hline Co & 4.3 & 0.15 & 9.9 & 0.64 & 0.07 & 0.08 & 12.8 & 0.67 & 11.1 & 0.38 \\
\hline $\mathrm{Ni}$ & 25.1 & 1.9 & 49.1 & 3.3 & 13 & 7.1 & 51.9 & 8.2 & 58.1 & 2.4 \\
\hline $\mathrm{Cu}$ & 16.7 & 1.9 & 41.6 & 4.6 & 49.6 & 4.1 & 21.7 & 4.2 & 35.3 & 2.7 \\
\hline $\mathrm{Zn}$ & 52.9 & 1.3 & 83 & 3.8 & 32.2 & 22.5 & 58.8 & 3.2 & 84.8 & 3 \\
\hline As & 1.6 & & 4.8 & 1.9 & 4.3 & & 13.5 & 1.1 & 5.2 & 0.32 \\
\hline $\mathrm{Rb}$ & 34.9 & 0.4 & 23.3 & 0.24 & 2.3 & 0.62 & 76.3 & 1.4 & 93.6 & 0.41 \\
\hline $\mathrm{Sr}$ & 473 & 4 & 1300 & 5.8 & 419 & 7.7 & 353 & 1.5 & 318 & 1.2 \\
\hline $\mathrm{Y}$ & 18 & 0.35 & 57.6 & 1.1 & 5.2 & 0.4 & 19.8 & 0.2 & 20.8 & 0.57 \\
\hline $\mathrm{Zr}$ & 47.5 & 1.4 & 106 & 2.1 & 16.2 & 13.7 & 106 & 0.1 & 101 & 2.41 \\
\hline $\mathrm{Nb}$ & 4.9 & 0.13 & 12.9 & 0.25 & 40.7 & 2.2 & 13.4 & 1.29 & 14.9 & 0.29 \\
\hline $\mathrm{Sn}$ & 6.2 & 0.19 & 13 & 0.22 & 3.1 & 0.75 & 6.2 & 0.21 & 6.6 & 0.37 \\
\hline $\mathrm{Sb}$ & & & & & & & & & 0.33 & 0.01 \\
\hline Cs & 2.2 & 0.03 & 0.29 & 0.04 & 0.19 & 0.05 & 6 & 0.26 & 7.2 & 0.04 \\
\hline $\mathrm{Ba}$ & 58.8 & 0.8 & 112 & 1.1 & 22.7 & 2.9 & 121 & 0.89 & 131 & 1.2 \\
\hline $\mathrm{La}$ & 21.3 & 0.31 & 50.6 & 0.98 & 4.9 & 0.55 & 27 & 0.08 & 29.6 & 0.13 \\
\hline $\mathrm{Ce}$ & 32 & 0.52 & 71.1 & 0.64 & 4.9 & 0.47 & 49 & 0.32 & 51 & 0.56 \\
\hline $\mathrm{W}$ & 1.1 & 0.06 & 1.5 & 0.97 & 3.6 & 0.16 & 1.48 & 0.23 & 1.1 & 0.5 \\
\hline $\mathrm{Tl}$ & 0.01 & & & & 0.02 & 0.01 & 0.01 & 0.004 & & \\
\hline $\mathrm{Pb}$ & 4.9 & 0.3 & 4.5 & 0.19 & 11.6 & 0.78 & 9.7 & 0.23 & 11.4 & 0.45 \\
\hline $\mathrm{Bi}$ & 0.08 & 0.08 & 0.22 & & 0.2 & & 0.19 & 0.01 & 0.19 & 0.03 \\
\hline $\mathrm{U}$ & 1 & 0.01 & 2.1 & 0.14 & 0.26 & 0.02 & 1.6 & 0.12 & 1.5 & 0.09 \\
\hline
\end{tabular}




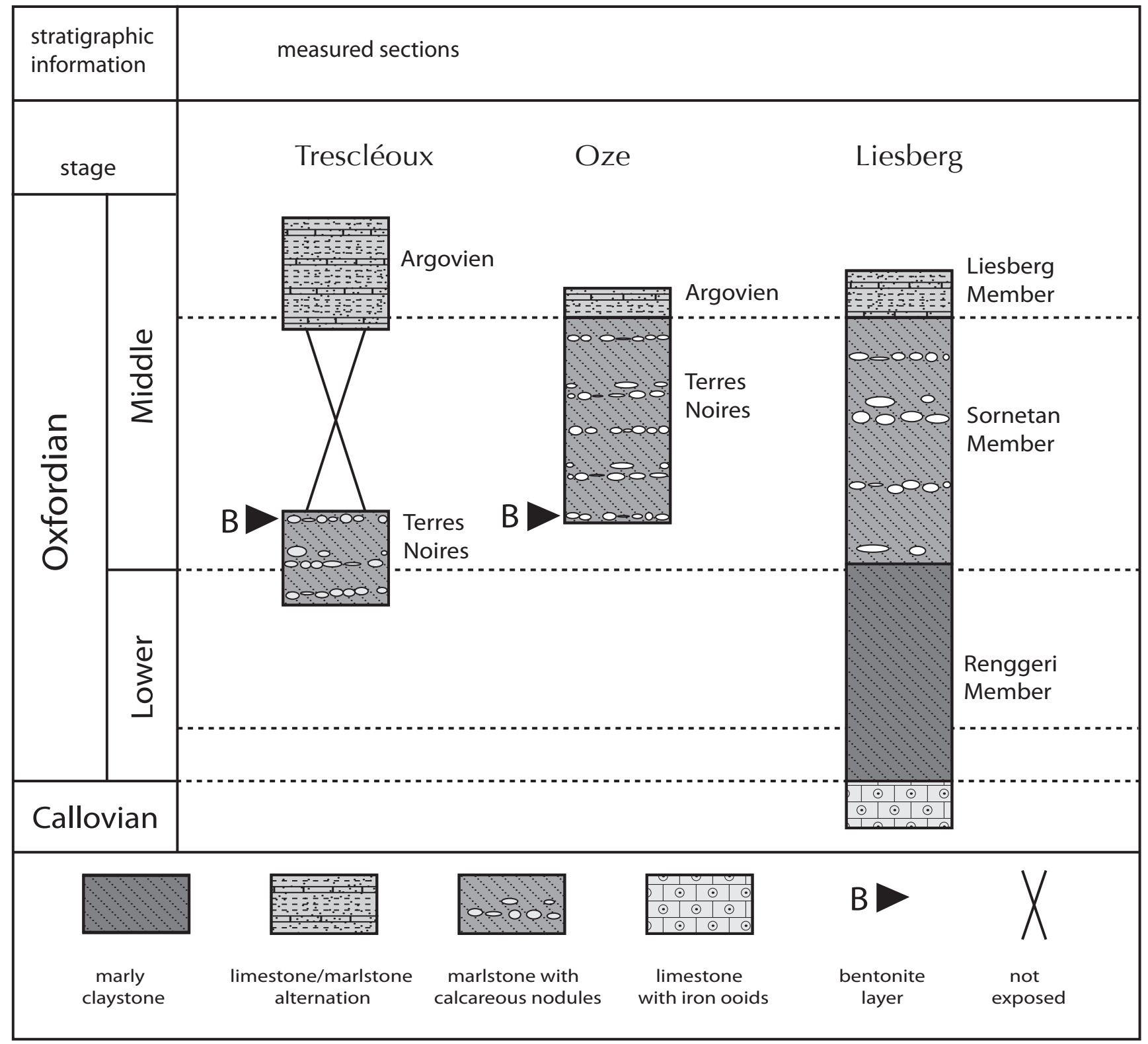

Fig. (2). Lithology and formation names of the studied sections. After Louis-Schmid et al. [2].

$\mathrm{P}$ values are as high as $2240 \mathrm{ppm}$ at the upper limit of the $\partial^{13} \mathrm{C}$ excursion. A concentration of $\mathrm{P}$ as high as $16700 \mathrm{ppm}$ is registered at the lower end of the "Terre Noires" (not shown in Fig. 3). Sc, Sr, Y, La and Ce show a concentration pattern similar to $\mathrm{P}, \mathrm{La}$ and $\mathrm{Ce}$ exhibit a distinct peak within the lower part of the profile (not shown in Fig. 3). Rb and Cs show a concentration pattern similar to $\mathrm{P}$ but without the typical peak at the upper limit or the $\partial^{13} \mathrm{C}$ excursion.

The concentration of $\mathrm{V}$ and $\mathrm{U}$ fluctuate evenly with the distinct drop within the zone of the negative spike concerning $\partial^{13} \mathrm{C}$. U solely exhibits a characteristic peak in concentration within the middle part of the profile. $\mathrm{Cr}$, Co and $\mathrm{Ni}$ belong to this group as well but exhibit greater fluctuations within the middle part of the profile.
Ti exhibits a spike of $12600 \mathrm{ppm}$ similar to $\mathrm{P}$ at the upper limit of the $\partial^{13} \mathrm{C}$ excursion. Ti fluctuates distinctly within the lower part of the profile and reaches more constant values within the part just below the $\partial^{13} \mathrm{C}$ excursion in the strict sense. $\mathrm{Zr}$ behaves similar to $\mathrm{Ti}$ but without the apparent spike of $\mathrm{Ti}$. The variations in concentration of $\mathrm{Nb}$ and $\mathrm{W}$ resemble more or less this for Ti.

Mn and Fe have a distinct profile of their own, with high concentrations within the lower part of the section. A striking peak (Mn: 2600 ppm, Fe: 36700 ppm) occurs again similar to $\mathrm{P}$ at the upper limit of the $\partial^{13} \mathrm{C}$ excursion.

The concentrations of $\mathrm{Cu}$ and $\mathrm{As}$ are evenly distributed below the $\partial^{13} \mathrm{C}$ excursion. The usual spike within the $\partial^{13} \mathrm{C}$ excursion is as evident as for $\mathrm{P}$ and $\mathrm{Ti}$. $\mathrm{Bi}$ is similar to $\mathrm{Cu}$ 

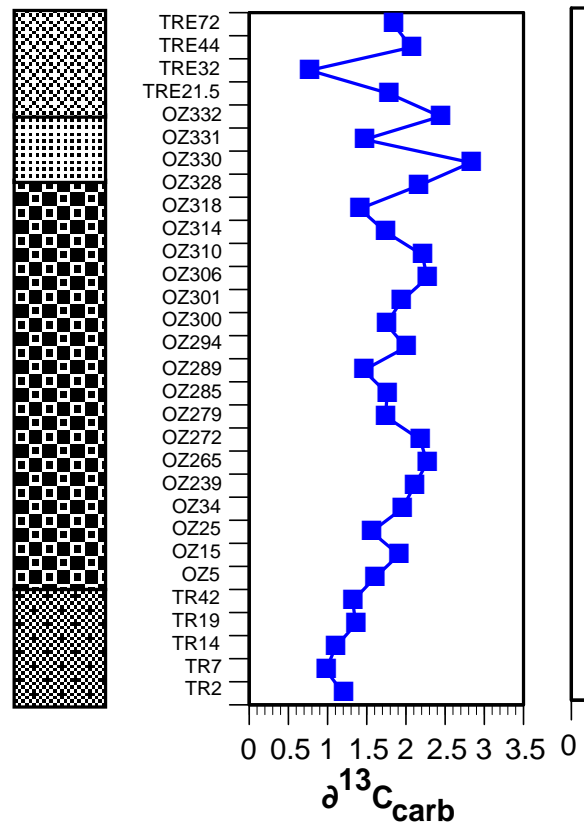

(Na)

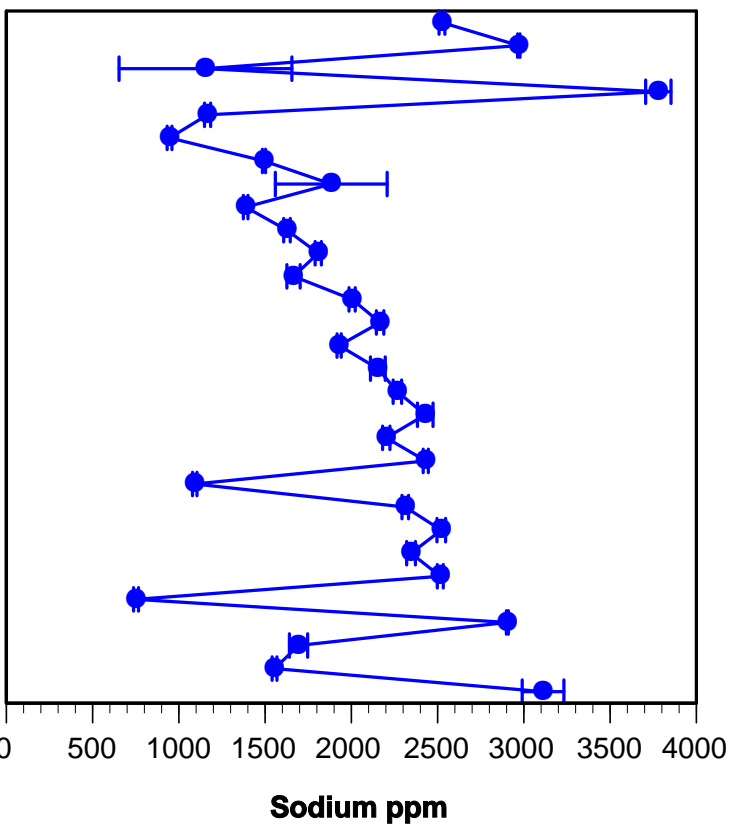

Trescléoux

Marlstone with calcareous nodules

Terres Noires

Oze

Marlstone with calcareous nodules

Terres Noires

Oze

Limestone/marlstone alternation

Argovien

Trescléoux

Limestone/marlstone alternation

Argovien

(Mg)
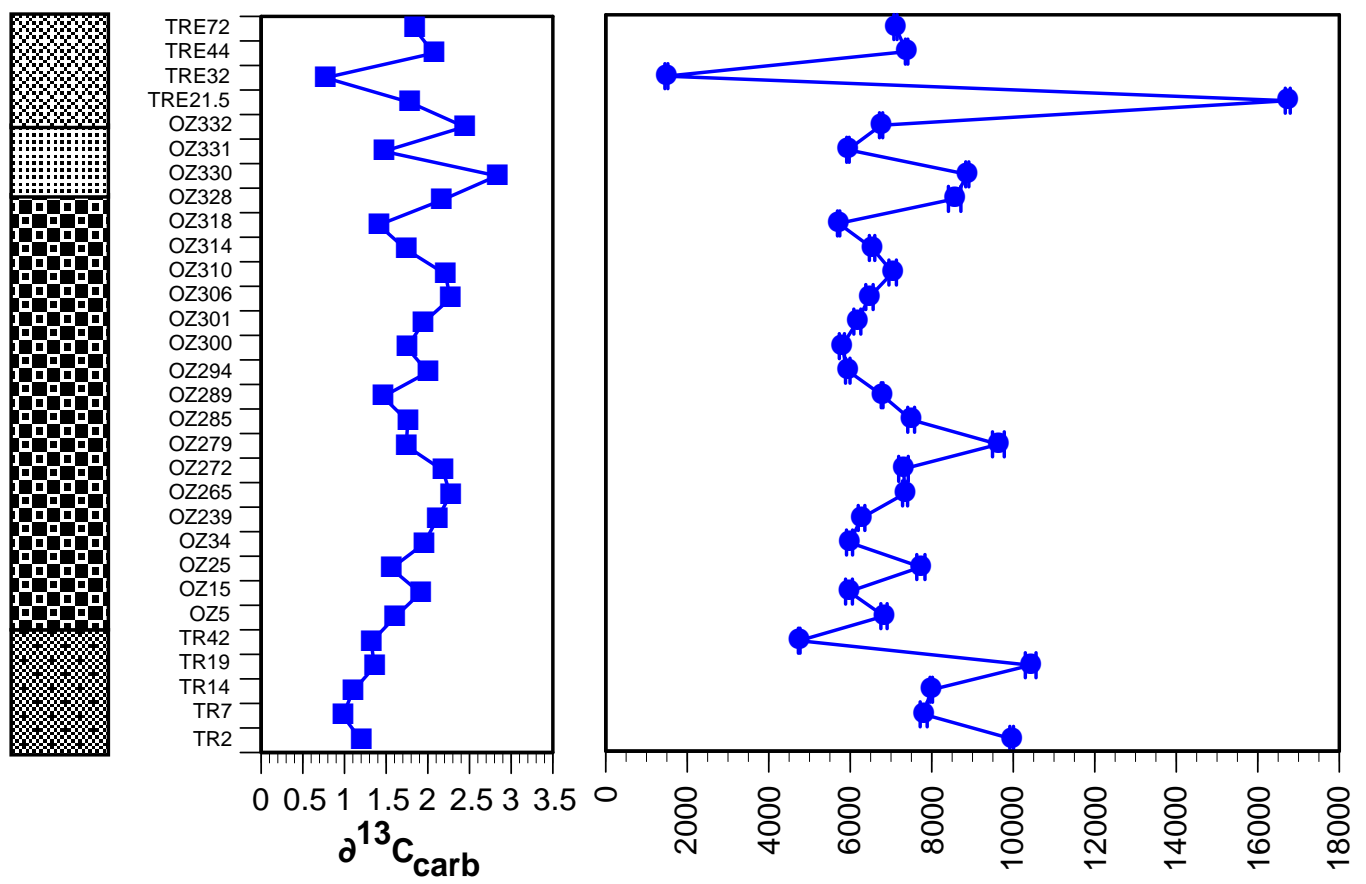

Magnesium ppm 
(Fig. 3) contd.....

(Ai)
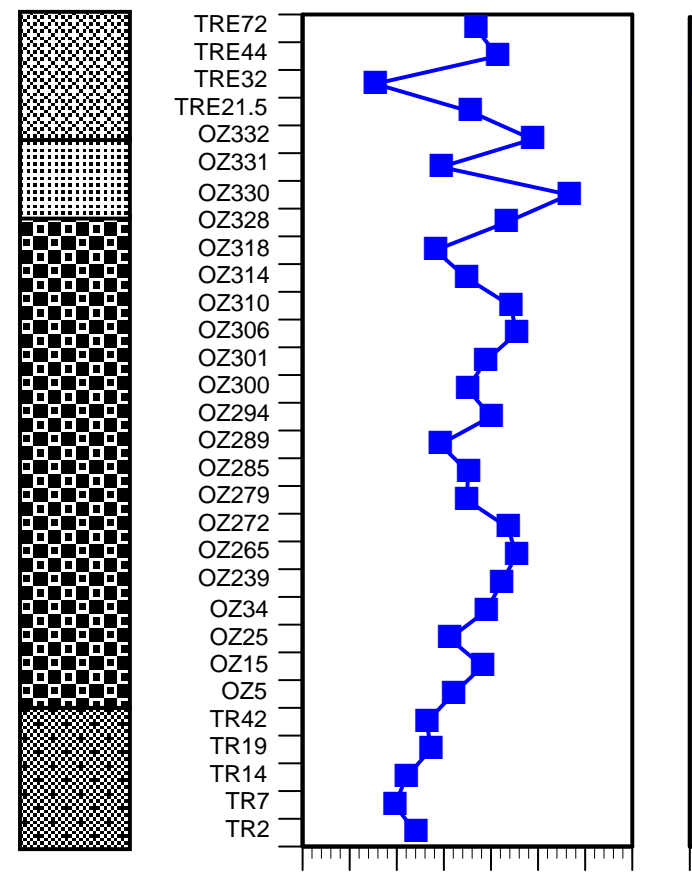

00.511 .522 .533 .50 $\partial^{13} \mathrm{C}_{\text {carb }}$

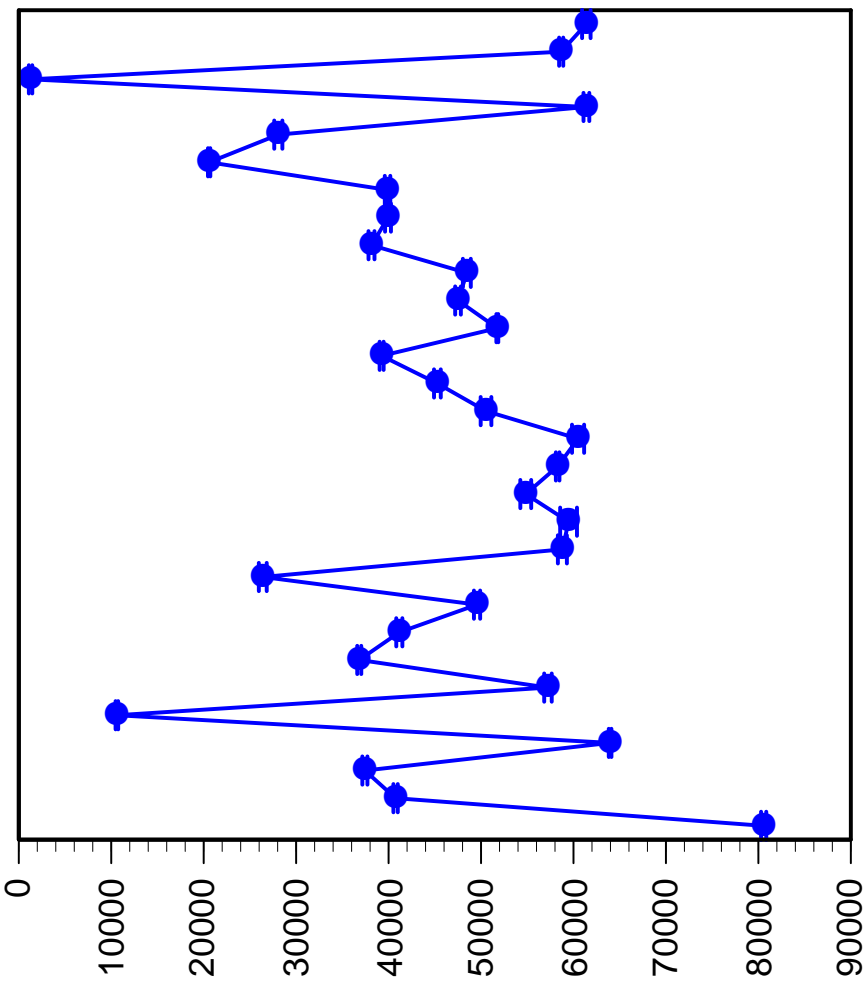

Alumimium ppm

(P)
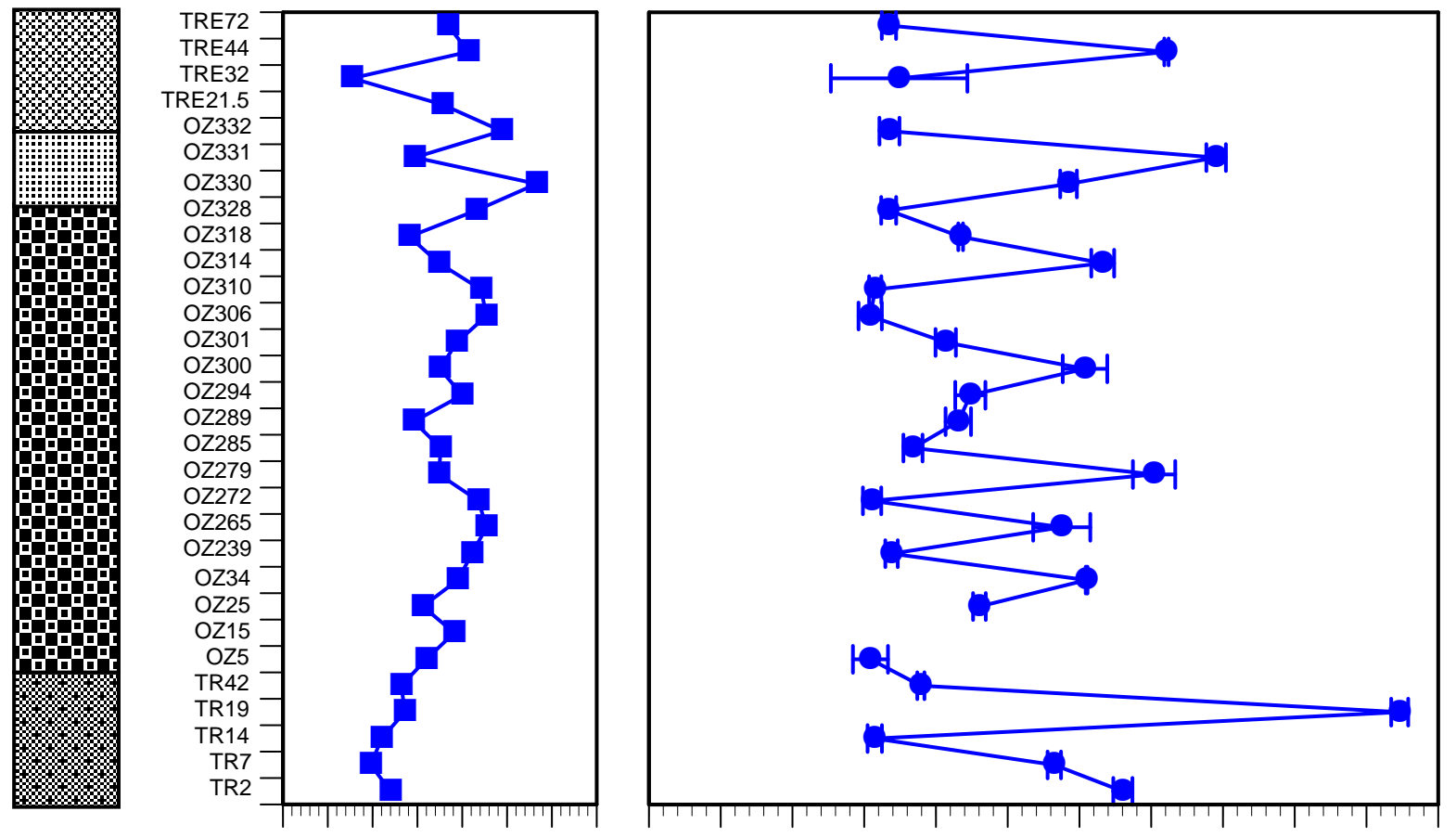

00.511 .522 .533 .50 $\partial^{13} C_{\text {carb }}$ 
(Ti)

(Fig. 3) contd.....

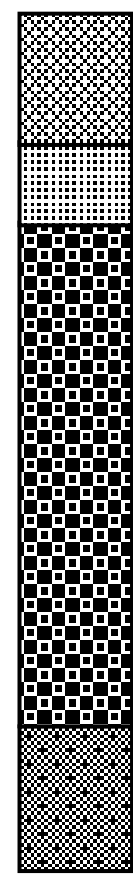

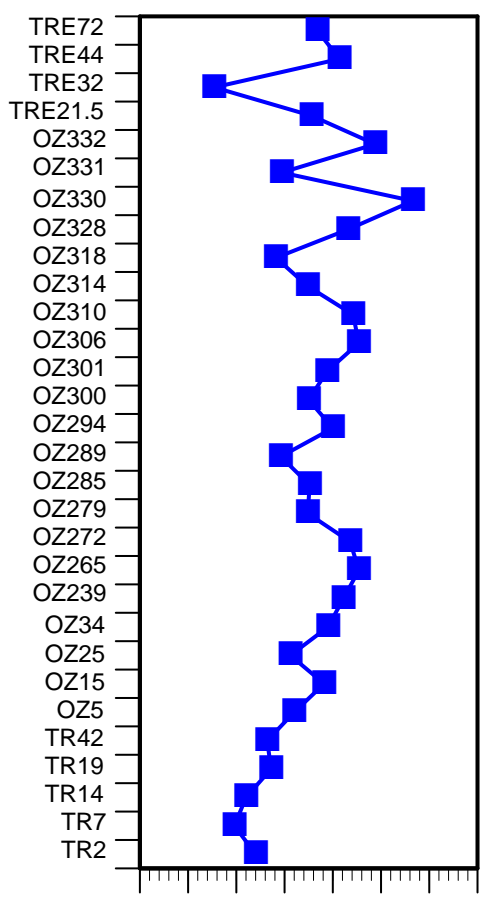

00.511 .522 .533 .50 $\partial^{13} C_{\text {carb }}$

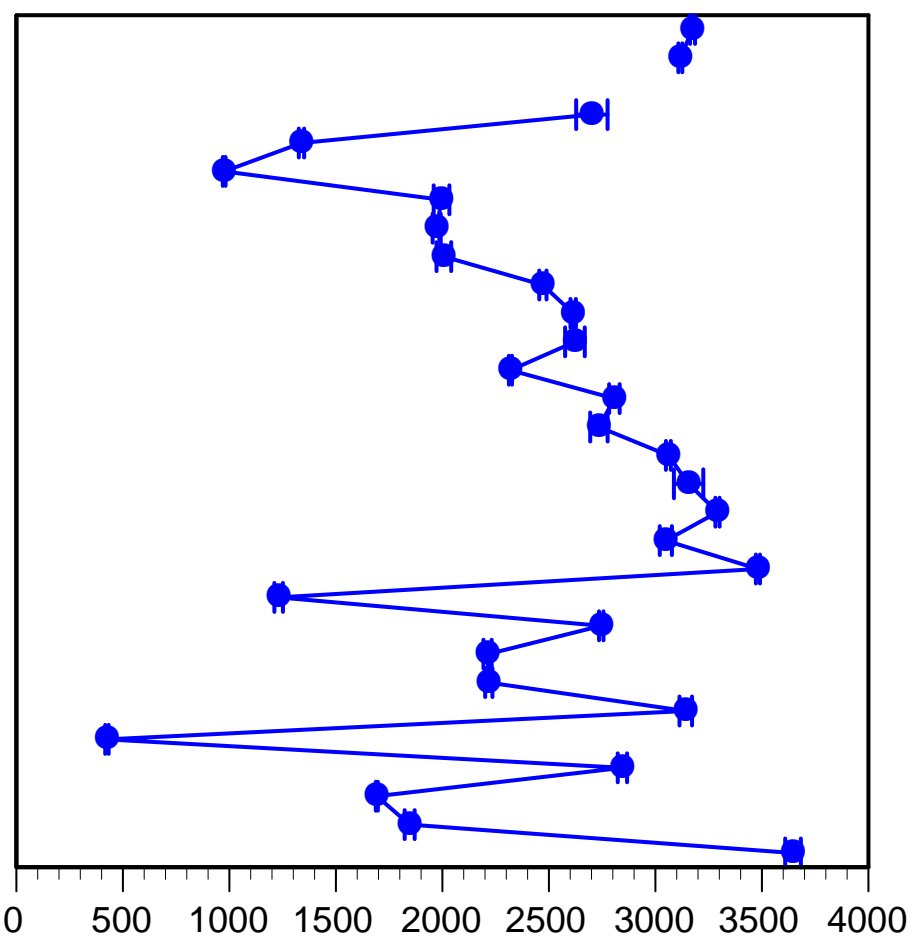

Titanium ppm

(V)
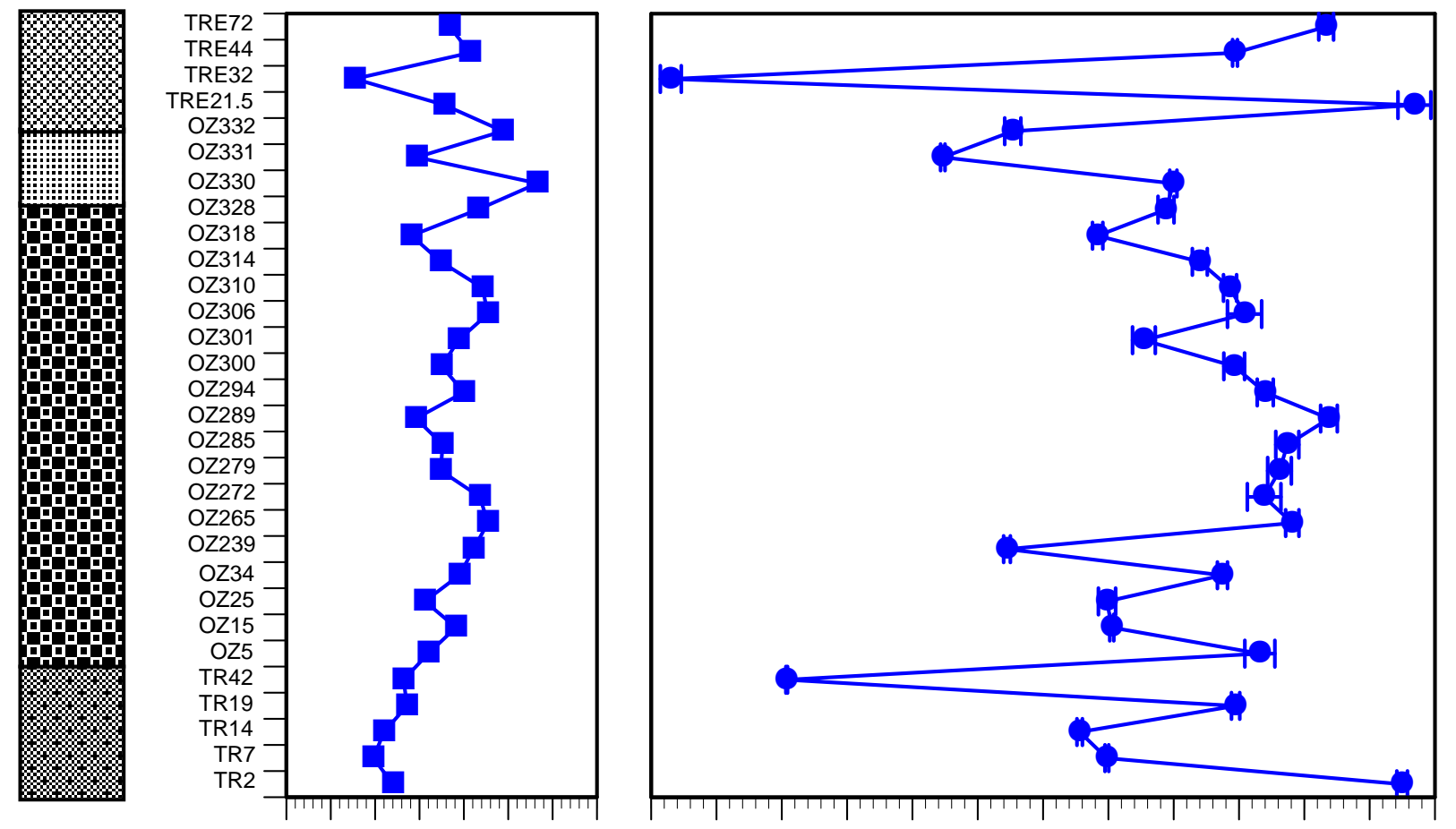

00.511 .522 .533 .50 $\partial^{13} C_{\text {carb }}$ 
(Fig. 3) contd.....

(Mn)
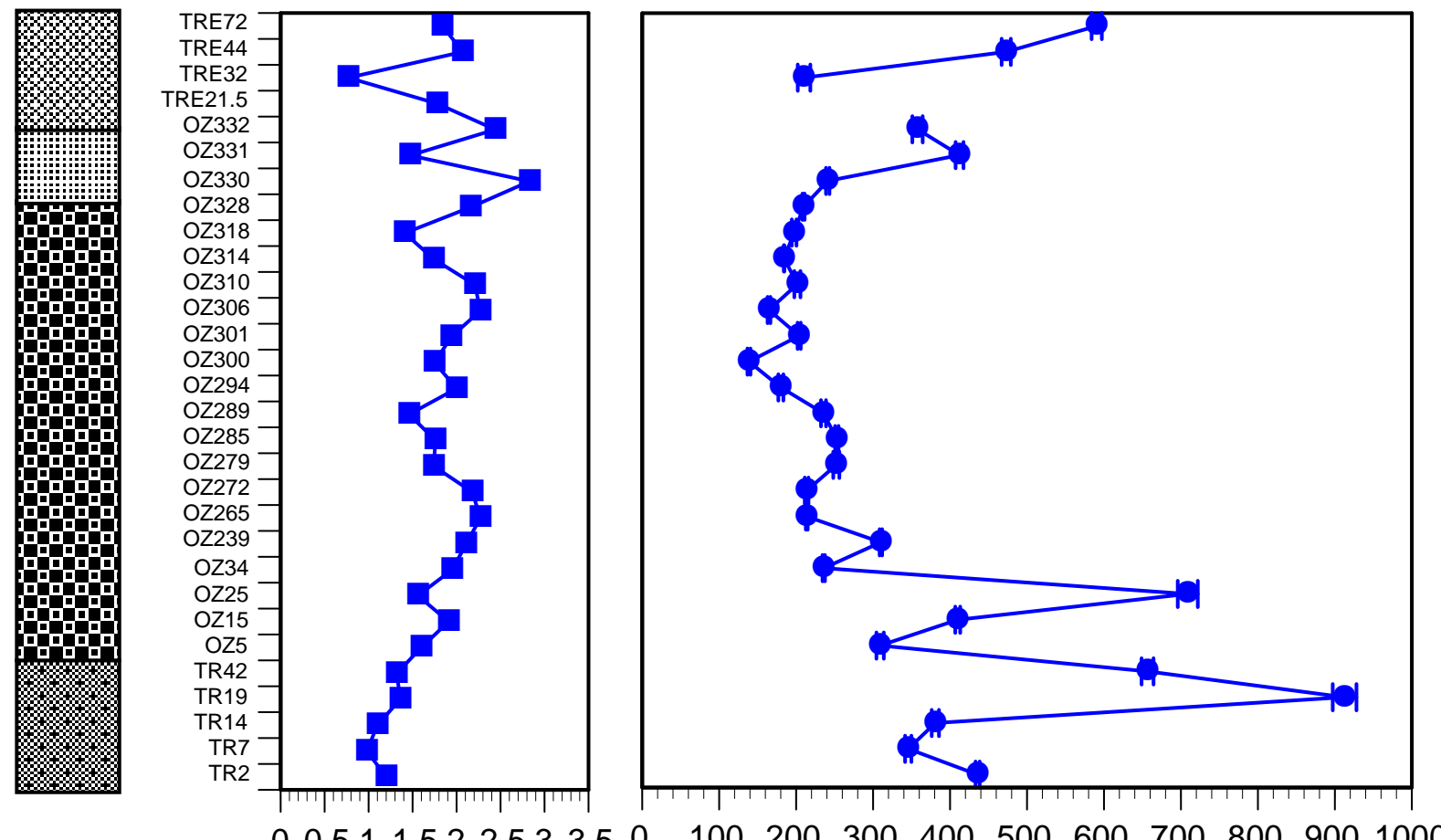

$00.511 .522 .533 .50 \quad 100200 \quad 300 \quad 400 \quad 500 \quad 600 \quad 700 \quad 800 \quad 9001000$ $\partial^{13} C_{\text {carb }}$

Manganese ppm

(Fe)
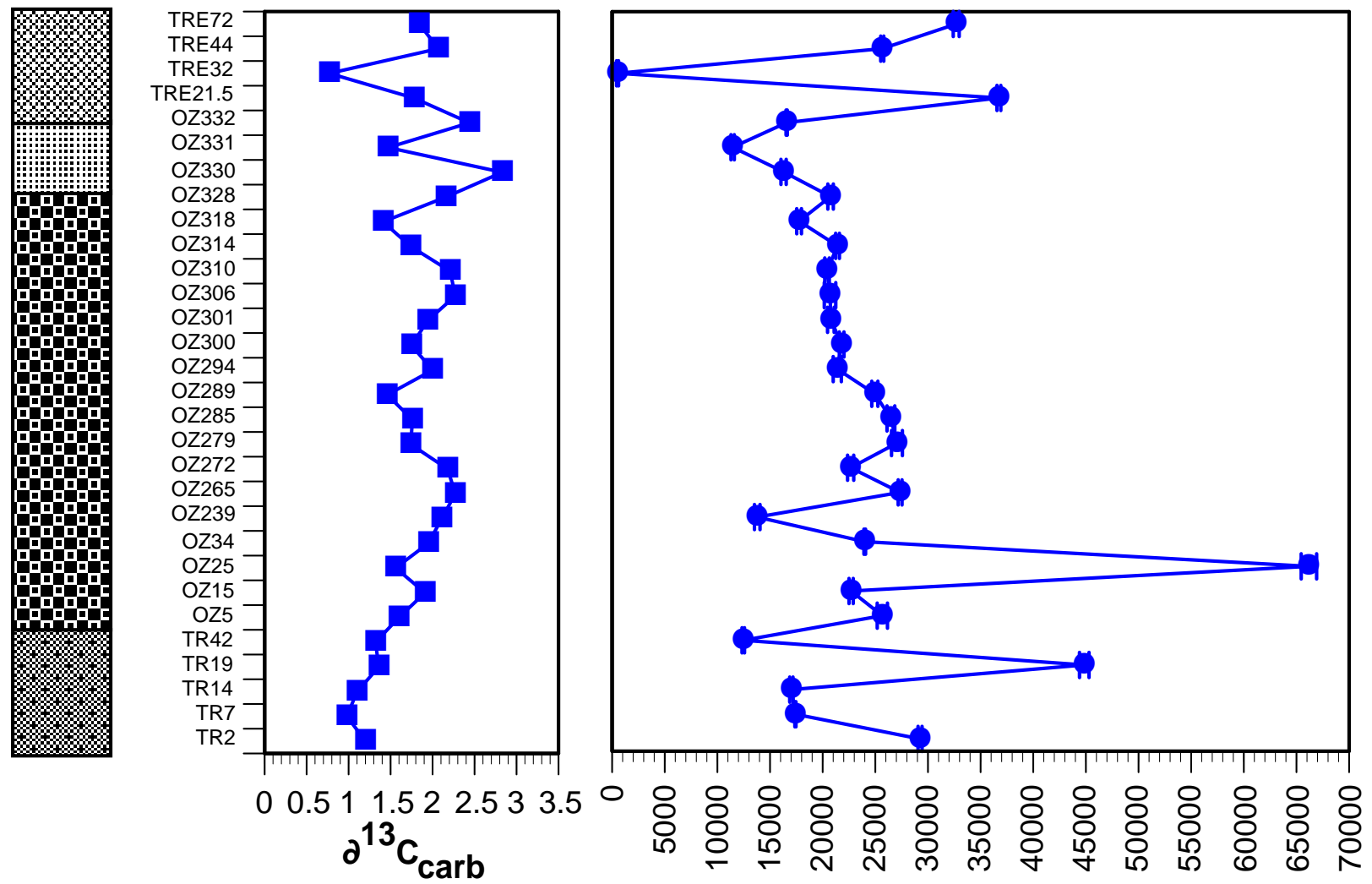

Iron ppm 
$(\mathbf{C u})$
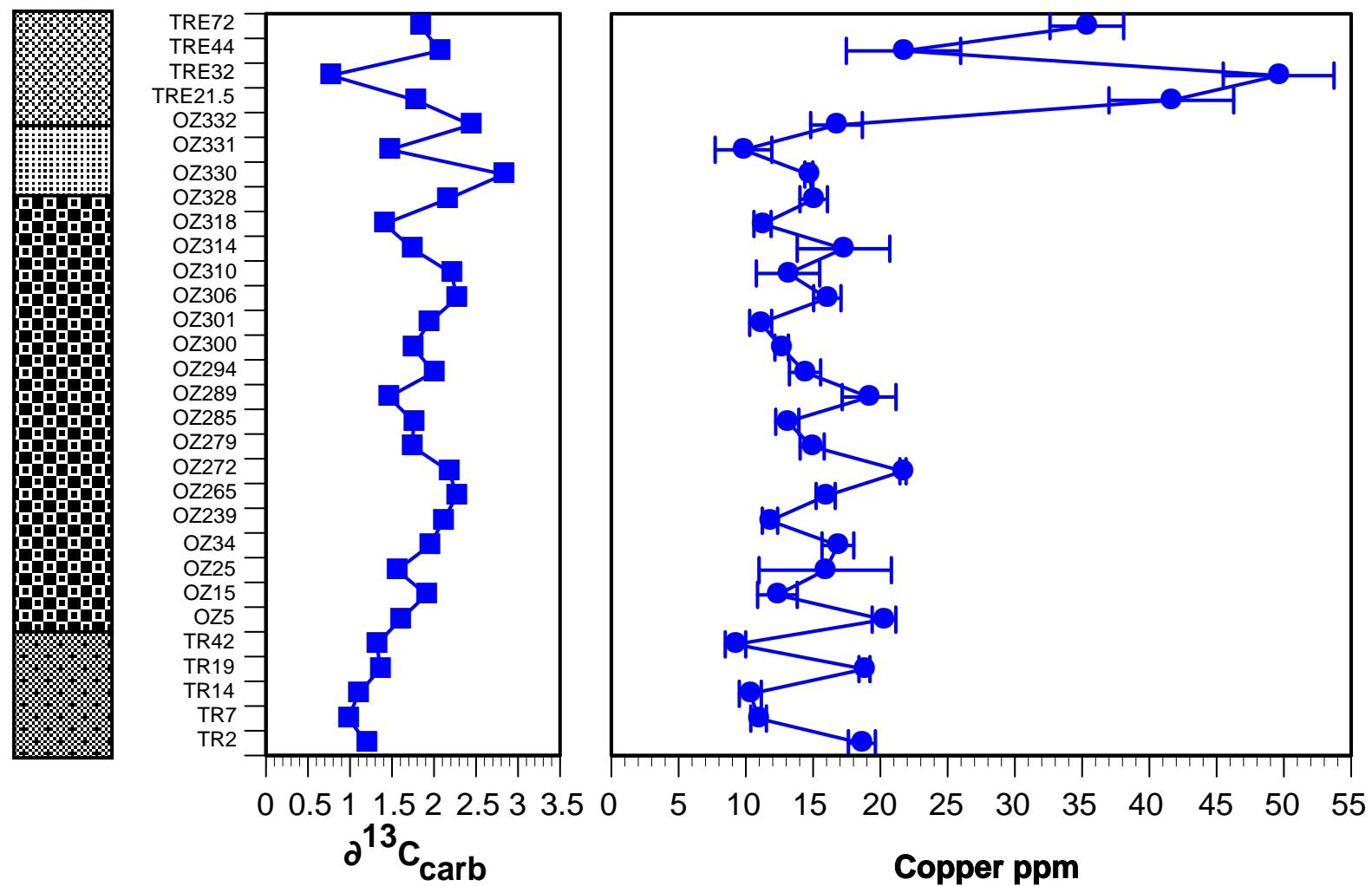

(Sr)
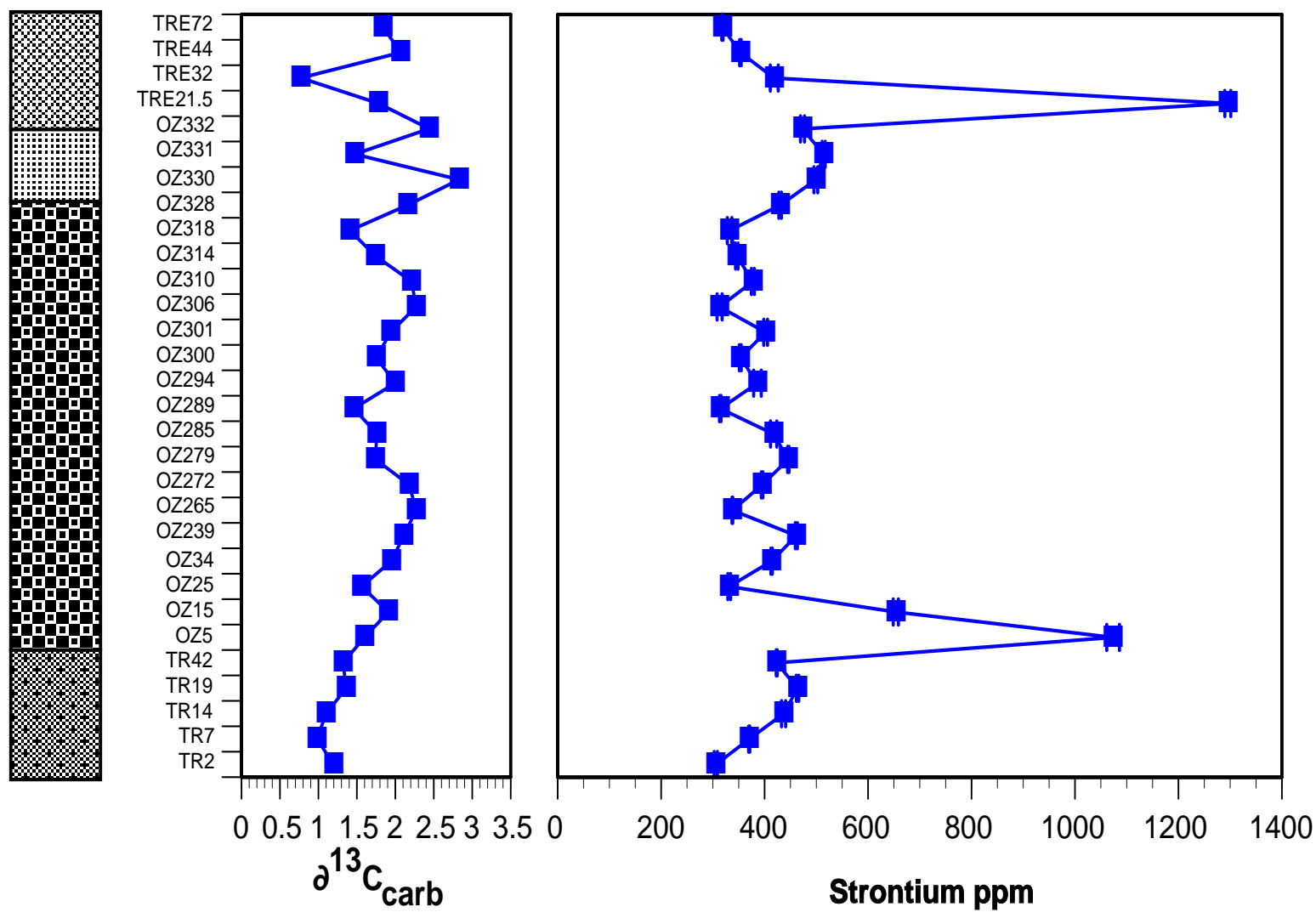
(Fig. 3) contd.....

(Ba)
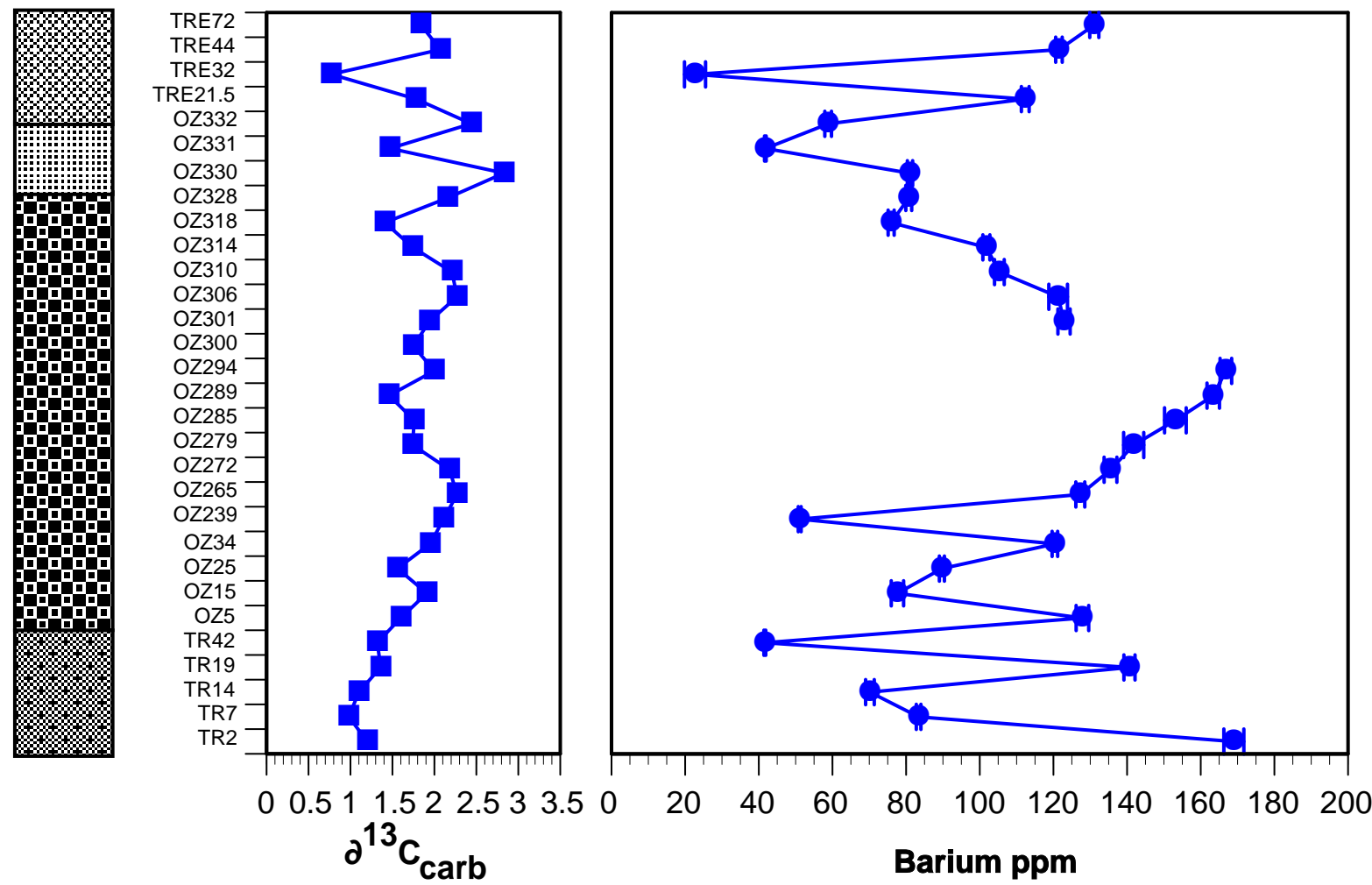

(Ce)
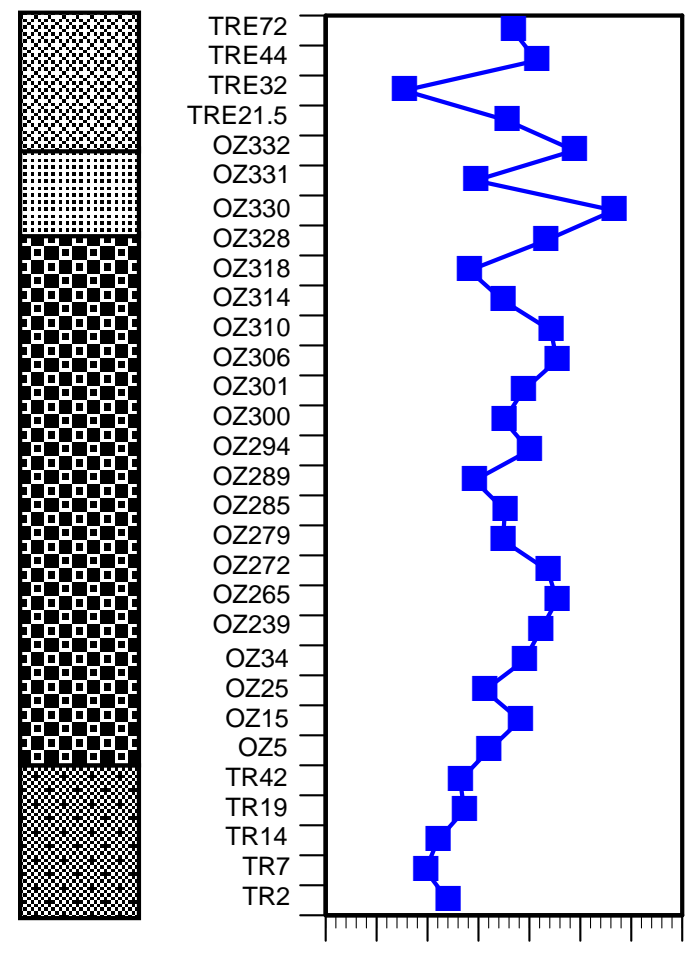

00.511 .522 .533 .50 $\partial^{13} C_{\text {carb }}$

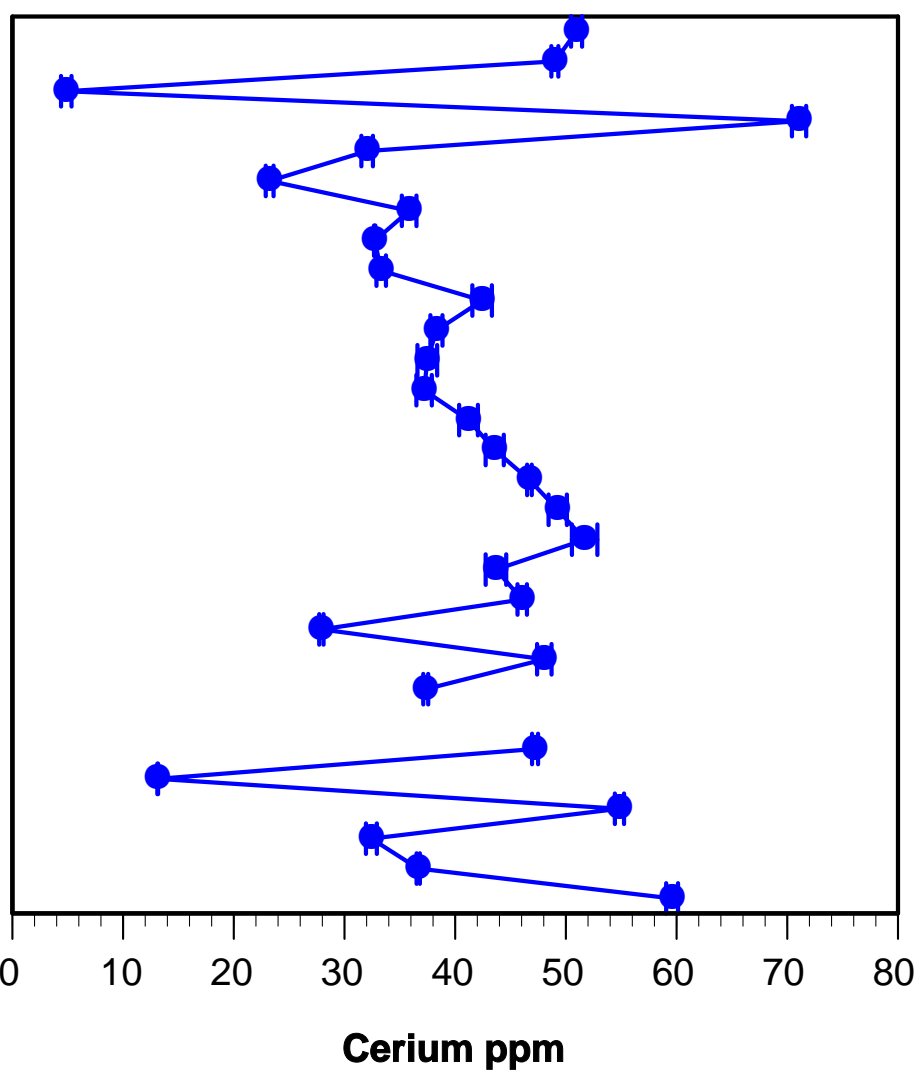


$(\mathbf{U})$
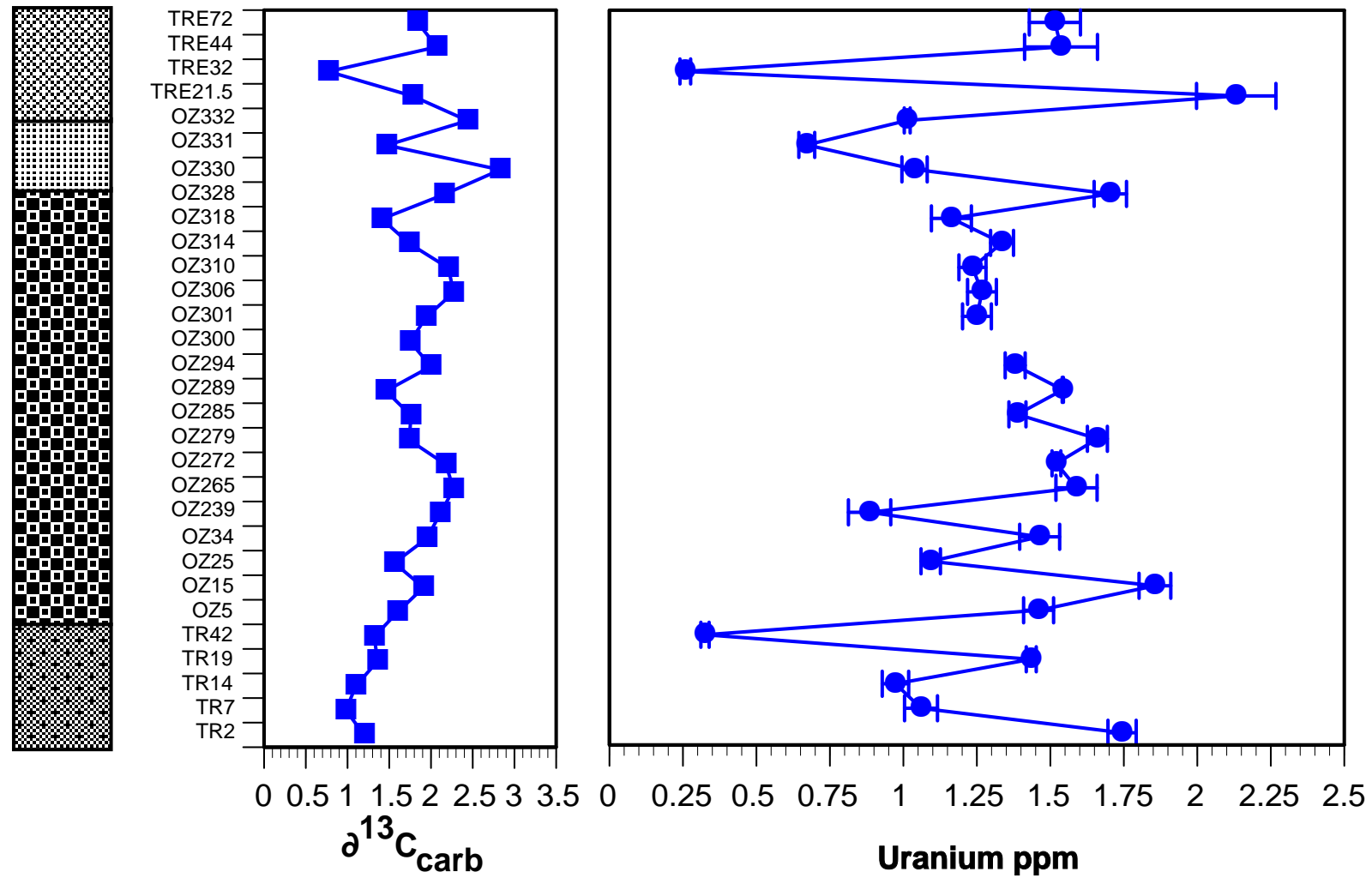

Fig. (3). Concentration patterns of the elements $\mathbf{N a}, \mathbf{M g}, \mathbf{A l}, \mathbf{P}, \mathbf{T i}, \mathbf{V}, \mathbf{M n}, \mathbf{F e}, \mathbf{C u}, \mathbf{S r}, \mathbf{B a}, \mathbf{C e}$, $\mathbf{U}$ with their respective error bars (proportional to their standard deviation) for all of the samples analyzed. The sample denominations are equal to their respective height within the profile.

and As and shows an obvious peak just at the beginning of the $\partial^{13} \mathrm{C}$ excursion.

$\mathrm{Zn}$ does not show any distinct peak or drop in concentration within the whole profile. $\mathrm{Sn}$ and $\mathrm{Pb}$ belong to this group as well.

$\mathrm{Sb}$ together with $\mathrm{Tl}$ are elements with few statistically relevant measurements and, therefore, it is difficult to discern any particular pattern in concentrations.

$\mathrm{Ba}$ concentrations fluctuate within the lower part of the profile and increase steadily to values up to $600 \mathrm{ppm}$ within the middle part before dropping again. No distinct peak within the $\partial^{13} \mathrm{C}$ excursion can be seen.

Table 2 presents the major and minor element/Al ratios of average shale and marine sediments in $\mathrm{ppm}$ and the corresponding enrichment factors (EF) regarding $\mathrm{Al}$ in marine sediments. The EF is defined as follows:

$\mathrm{EF}=(\text { element } / \mathrm{Al})_{\text {sample }} /(\text { element } / \mathrm{Al})_{\text {shale }}$

$\mathrm{Al}$ is the most important element essentially not affected by biological or diagenetic processes in marine environments. Al forms part of the structural component of most minerals introduced via fluvial and aeolian sources and, therefore, it seems to be the element of choice for quantifying the terrigenous-detrital fraction in marine environments. Another advantage of $\mathrm{Al}$ is its high concentration in alumosilicates and rather low abundance in seawater [18]. Any deviation from average shale composition and, therefore, either excess or depletion, is easily seen in element/Al-ratios. Any relative enrichment then is expressed by an $\mathrm{EF}>1$, whereas depleted elements have an $\mathrm{EF}<1$

Among the major elements, $\mathrm{Na}$ and $\mathrm{Mg}$ show clear $\mathrm{EF}$ above 1 in the lower part. Another EF clearly above 1 is seen for in the uppermost part of the profile ("Argovien"). Si and $\mathrm{K}$ EFs oscillate constantly around 1 .

Among minor and trace elements $\mathrm{P}, \mathrm{Sr}, \mathrm{Y}, \mathrm{La}, \mathrm{Ce}$ exhibit a peak EF in the lower part ("Terre Noires") of the profile and again in the uppermost part of the profile ("Argovien") similar to $\mathrm{Mg}$. Above all $\mathrm{Sr}$ shows a distinct enrichment among the whole profile. $\mathrm{V}, \mathrm{Rb}, \mathrm{Co}$, and $\mathrm{Ni}$, never show a distinct enrichment with the exception within the uppermost part of the profile. $\mathrm{Cr}$ and $\mathrm{Sn}$ often exhibits enrichment factor around 2 and again a peak in EF in the "Argovien" section. As an exception $\mathrm{Ba}$ as well as $\mathrm{U}$ exhibit high EFs in the middle part of the profile and again in the uppermost part. $\mathrm{Ti}, \mathrm{Zr}, \mathrm{Nb}, \mathrm{W}$ and including $\mathrm{Sc}$ oscillate the same way as $\mathrm{Si}$ with the exception that $\mathrm{Ti}, \mathrm{Zr}, \mathrm{Nb}$ and $\mathrm{W}$ are highly enriched compared to Al in the average shale in the uppermost part of the profile ("Argovien"). Fe is broadly similar to Mn with the exception of the lack of enrichment in the "Argovien". $\mathrm{Cu}, \mathrm{As}$, and $\mathrm{Pb}$ commonly oscillate around 
Table 2a. Major and Minor Element/Al Ratios of Average Shale and Marine Sediments in ppm and Enrichment Factors in Marine Sediments

\begin{tabular}{|c|c|c|c|c|c|c|c|c|}
\hline & Average & $\begin{array}{c}\text { Element/ } \\
\text { Al Ratio }\end{array}$ & $\begin{array}{c}\text { Element/ } \\
\text { Al Ratio }\end{array}$ & $\begin{array}{c}\text { Element/ } \\
\text { Al Ratio }\end{array}$ & $\begin{array}{c}\text { Element/ } \\
\text { Al Ratio }\end{array}$ & $\begin{array}{c}\text { Element/ } \\
\text { Al Ratio }\end{array}$ & $\begin{array}{c}\text { Element/ } \\
\text { Al Ratio }\end{array}$ & $\begin{array}{l}\text { Element } \\
\text { Al Ratio }\end{array}$ \\
\hline & & av. shale & TR2 & TR7 & TR14 & TR19 & TR42 & OZ5 \\
\hline $\mathrm{Na}$ & 11870 & 0.13 & 0.039 & 0.038 & 0.045 & 0.045 & 0.071 & 0.044 \\
\hline $\mathrm{Mg}$ & 15679 & 0.18 & 0.124 & 0.191 & 0.213 & 0.163 & 0.448 & 0.119 \\
\hline $\mathrm{Al}$ & 88387 & & & & & & & \\
\hline $\mathrm{Si}$ & 275322 & 3.11 & 2.34 & 2.28 & 2.44 & 2.45 & 2.93 & 3.79 \\
\hline $\mathrm{P}$ & 698 & 0.008 & 0.004 & 0.007 & 0.004 & 0.008 & 0.018 & 0.003 \\
\hline $\mathrm{K}$ & 29885 & 0.34 & 0.222 & 0.197 & 0.212 & 0.213 & 0.144 & 0.202 \\
\hline $\mathrm{Sc}$ & 13 & $1.5^{*}$ & 1.518 & 1.61 & 1.65 & 1.52 & 1.95 & 1.64 \\
\hline $\mathrm{Ti}$ & 4674 & 0.053 & 0.045 & 0.045 & 0.045 & 0.044 & 0.04 & 0.055 \\
\hline $\mathrm{V}$ & 130 & $15^{*}$ & 14.27 & 17.12 & 17.53 & 13.99 & 19.56 & 16.28 \\
\hline $\mathrm{Cr}$ & 90 & $10.2 *$ & 18.18 & 15.23 & 15.38 & 13.96 & 26.93 & 15.29 \\
\hline $\mathrm{Mn}$ & 850 & $96^{*}$ & 54.09 & 84.81 & 101.7 & 142.89 & 619 & 54 \\
\hline $\mathrm{Fe}$ & 48261 & 0.55 & 0.363 & 0.43 & 0.46 & 0.701 & 1.17 & 0.448 \\
\hline Co & 19 & $2.1^{*}$ & 1.51 & 1.43 & 1.83 & 1.38 & 1.24 & 1.53 \\
\hline $\mathrm{Ni}$ & 68 & $7.7 *$ & 8.37 & 7.41 & 9.84 & 7.14 & 11.59 & 9.03 \\
\hline $\mathrm{Cu}$ & 45 & $5.1^{*}$ & 2.31 & 2.69 & 2.76 & 2.94 & 8.7 & 3.54 \\
\hline $\mathrm{Zn}$ & 95 & $11^{*}$ & 8.61 & 10.09 & 11.42 & 8.82 & 31.9 & 12.63 \\
\hline As & 10 & $1.1^{*}$ & 1.71 & 1.6 & 1.19 & 0.59 & 0.653 & 0.613 \\
\hline $\mathrm{Rb}$ & 140 & $16^{*}$ & 12.17 & 11.92 & 12.11 & 11.63 & 8.26 & 11.37 \\
\hline $\mathrm{Sr}$ & 300 & $34^{*}$ & 37.93 & 90.84 & 116.7 & 72.5 & 399.19 & 187.58 \\
\hline $\mathrm{Y}$ & 41 & $4.6^{*}$ & 2.5 & 4.08 & 3.76 & 3.45 & 11.91 & 3.07 \\
\hline $\mathrm{Zr}$ & 160 & $18^{*}$ & 16.17 & 16.07 & 16 & 15.18 & 15.83 & 23.97 \\
\hline $\mathrm{Nb}$ & 18 & $2.0^{*}$ & 1.82 & 1.69 & 1.75 & 1.73 & 1.61 & 2.3 \\
\hline $\mathrm{Sn}$ & 6.0 & $0.67 *$ & 0.714 & 1.09 & 1.29 & 0.912 & 3.72 & 0.762 \\
\hline $\mathrm{Sb}$ & 1.5 & $0.17 *$ & & 0.055 & & & & \\
\hline Cs & 5.5 & $0.62 *$ & 0.965 & 0.704 & 0.625 & 0.861 & 0.362 & 0.845 \\
\hline $\mathrm{Ba}$ & 580 & $66^{*}$ & 20.97 & 20.46 & 18.75 & 22 & 39.25 & 22.34 \\
\hline $\mathrm{La}$ & 40 & $4.5^{*}$ & 3.84 & 5.17 & 5.08 & 4.63 & 10.53 & 4.46 \\
\hline $\mathrm{Ce}$ & 95 & $10.7^{*}$ & 7.4 & 9 & 8.66 & 8.57 & 12.37 & 8.25 \\
\hline W & 1.8 & $0.20 *$ & 0.176 & 0.212 & 0.203 & 0.164 & 0.823 & 0.201 \\
\hline $\mathrm{Tl}$ & 0.68 & $0.077^{*}$ & 0.005 & & 0.005 & & & 0.004 \\
\hline $\mathrm{Pb}$ & 22 & $2.5^{*}$ & 1.55 & 1.55 & 1.63 & 1.253 & 0.7 & 1.95 \\
\hline $\mathrm{Bi}$ & 0.1 & $0.015^{*}$ & 0.031 & 0.031 & 0.036 & 0.026 & 0.057 & 0.028 \\
\hline $\mathrm{U}$ & 3.7 & $0.42 *$ & 0.216 & 0.216 & 0.26 & 0.224 & 0.307 & 0.255 \\
\hline
\end{tabular}


Table 2b. Major and Minor Element/Al Ratios of Average Shale and Marine Sediments in ppm and Enrichment Factors in Marine Sediments

\begin{tabular}{|c|c|c|c|c|c|c|c|}
\hline & Element/AI Ratio & Element/Al Ratio & Element/AI Ratio & Element/Al Ratio & Element/AI Ratio & Element/Al Ratio & Element/Al Ratio \\
\hline $\mathrm{Mg}$ & 0.162 & 0.188 & 0.121 & 0.238 & 0.125 & 0.123 & 0.176 \\
\hline \multicolumn{8}{|l|}{$\mathrm{Al}$} \\
\hline $\mathrm{P}$ & 0.454 & 0.006 & 0.006 & 0.006 & 0.005 & 0.003 & 0.006 \\
\hline $\mathrm{K}$ & 0.208 & 0.204 & 0.221 & 0.178 & 0.223 & 0.21 & 0.231 \\
\hline $\mathrm{Sc}$ & 2.35 & 2.04 & 1.83 & 2 & 1.84 & 1.46 & 1.66 \\
\hline $\mathrm{Mn}$ & 111.3 & 172.22 & 47.59 & 117.5 & 36.36 & 35.92 & 45.99 \\
\hline $\mathrm{Fe}$ & 0.616 & 1.61 & 0.484 & 0.522 & 0.47 & 0.381 & 0.049 \\
\hline Co & 1.2 & 1.31 & 1.54 & 0.728 & 1.14 & 1.166 & 1.51 \\
\hline $\mathrm{Ni}$ & 9.23 & 10.66 & 8.99 & 7.38 & 8.3 & 6.65 & 7.61 \\
\hline $\mathrm{Cu}$ & 3.35 & 3.86 & 3.4 & 4.47 & 2.71 & 3.65 & 2.72 \\
\hline $\mathrm{Zn}$ & 19.21 & 16.38 & 11.79 & 14.75 & 9.36 & 15.27 & 9.34 \\
\hline $\mathrm{Nb}$ & 3.1 & 2.47 & 2.31 & 1.81 & 3.16 & 2.18 & 2.666 \\
\hline Sn & 0.9 & 1.74 & 1.51 & 1.64 & 0.64 & 1.23 & 0.773 \\
\hline $\mathrm{Sb}$ & & & 0.068 & & 0.123 & 0.058 & \\
\hline Cs & 0.82 & 0.9 & 0.93 & 0.18 & 1.01 & 1.01 & 1.03 \\
\hline $\mathrm{Ba}$ & 21.08 & 21.78 & 24.29 & 19.36 & 21.65 & 22.78 & 25.86 \\
\hline $\mathrm{La}$ & 33.1 & 2.01 & 5.49 & 7.22 & 4.49 & 4.37 & 5.55 \\
\hline $\mathrm{Ce}$ & 75.77 & 9.07 & 9.69 & 10.58 & 7.83 & 7.35 & 9.43 \\
\hline W & 0.21 & 0.218 & 0.18 & 0.24 & 0.127 & 0.192 & 0.221 \\
\hline $\mathrm{Tl}$ & & 0.007 & 0.002 & 0.005 & 0.024 & 0.001 & 0.012 \\
\hline $\mathrm{Pb}$ & 1.54 & 2.12 & 2.13 & 1.43 & 1.773 & 1.514 & 1.65 \\
\hline $\mathrm{Bi}$ & 0.055 & 0.04 & 0.034 & 0.04 & 0.04 & 0.032 & 0.0141 \\
\hline $\mathrm{U}$ & 0.504 & 0.266 & 0.295 & 0.335 & 0.27 & 0.256 & 0.303 \\
\hline
\end{tabular}


Table 2c. Major and Minor Element/Al Ratios of Average Shale and Marine Sediments in ppm and Enrichment Factors in Marine Sediments

\begin{tabular}{|c|c|c|c|c|c|c|c|}
\hline & $\begin{array}{c}\text { Element/ } \\
\text { Al Ratio }\end{array}$ & $\begin{array}{c}\text { Element/ } \\
\text { Al Ratio }\end{array}$ & $\begin{array}{c}\text { Element/ } \\
\text { Al Ratio }\end{array}$ & $\begin{array}{c}\text { Element/ } \\
\text { Al Ratio }\end{array}$ & $\begin{array}{c}\text { Element/ } \\
\text { Al Ratio }\end{array}$ & $\begin{array}{c}\text { Element/ } \\
\text { Al Ratio }\end{array}$ & $\begin{array}{c}\text { Element/ } \\
\text { Al Ratio }\end{array}$ \\
\hline & OZ285 & OZ289 & OZ94 & OZ300 & OZ301 & OZ306 & OZ310 \\
\hline $\mathrm{Na}$ & 0.039 & 0.036 & 0.038 & 0.048 & 0.051 & 0.032 & 0.038 \\
\hline $\mathrm{Mg}$ & 0.123 & 0.112 & 0118 & 0.118 & 0.157 & 0.125 & 0.148 \\
\hline \multicolumn{8}{|l|}{$\mathrm{Al}$} \\
\hline $\mathrm{Si}$ & 3.39 & 2.96 & 3.37 & 3.93 & 3.93 & 3.52 & 3.51 \\
\hline $\mathrm{P}$ & 0.003 & 0.004 & 0.004 & 0.007 & 0.005 & 0.003 & 0.003 \\
\hline $\mathrm{K}$ & 0.269 & 0.27 & 0.26 & 0231 & 0.234 & 0.26 & 0.209 \\
\hline $\mathrm{Sc}$ & 1.66 & 1.78 & 1.78 & 1.92 & 1.86 & 1.74 & 1.79 \\
\hline $\mathrm{Ti}$ & 0.54 & 0.054 & 0.054 & 0.062 & 0.059 & 0.051 & 0.055 \\
\hline $\mathrm{V}$ & 16.71 & 17.15 & 18.6 & 19.74 & 19.22 & 17.55 & 18.65 \\
\hline $\mathrm{Cr}$ & 21.09 & 19.18 & 21.92 & 14.94 & 15.52 & 24 & 21.3 \\
\hline $\mathrm{Mn}$ & 43.39 & 39.94 & 35.65 & 30.63 & 51.96 & 31.83 & 42.44 \\
\hline $\mathrm{Fe}$ & 0.454 & 0.412 & 0.42 & 0.48 & 0.529 & 0.4 & 0.43 \\
\hline Co & 1.56 & 1.32 & 1.65 & 1.67 & 1.26 & 0.916 & 0.93 \\
\hline $\mathrm{Ni}$ & 8.8 & 6.1 & 9.22 & 8.97 & 8.23 & 8.15 & 6.83 \\
\hline $\mathrm{Cu}$ & 2.24 & 3.17 & 2.85 & 2.8 & 2.83 & 3.1 & 2.76 \\
\hline $\mathrm{Zn}$ & 11.26 & 15.75 & 19.71 & 11.32 & 10.29 & 15.6 & 13.05 \\
\hline As & 0.723 & 0.56 & 0.79 & 1.09 & 0.811 & 0.75 & 0.666 \\
\hline $\mathrm{Rb}$ & 14.48 & 15.7 & 14.47 & 13.11 & 13.1 & 14.35 & 13.78 \\
\hline $\mathrm{Sr}$ & 71.63 & 51.96 & 76.41 & 77.96 & 102.7 & 60.78 & 79.43 \\
\hline $\mathrm{Y}$ & 3.15 & 2.76 & 3.86 & 3.94 & 4.21 & 3.18 & 3.59 \\
\hline $\mathrm{Zr}$ & 21.74 & 17.41 & 21.95 & 27.04 & 27.04 & 18.76 & 24.13 \\
\hline $\mathrm{Nb}$ & 2.16 & 2.07 & 2.36 & 3.01 & 2.91 & 2.2 & 2.2 \\
\hline $\mathrm{Sn}$ & 1.39 & 1.41 & 1.61 & 0.79 & 0.89 & 1.51 & 1.47 \\
\hline $\mathrm{Sb}$ & & & 0.09 & & 0.137 & & \\
\hline Cs & 1.06 & 1.15 & 1.11 & 1.05 & 1.02 & 1.14 & 1.14 \\
\hline $\mathrm{Ba}$ & 26.27 & 27 & 33 & 133.3 & 31.31 & 23.43 & 22.17 \\
\hline $\mathrm{La}$ & 4.94 & 4.47 & 5.47 & 5.32 & 5.93 & 4.44 & 4.89 \\
\hline $\mathrm{Ce}$ & 8.45 & 7.72 & 8.62 & 9.1 & 9.78 & 7.24 & 8.07 \\
\hline W & 0.212 & 0.223 & 0.204 & 0.244 & 0.215 & 0.261 & 0.26 \\
\hline $\mathrm{Tl}$ & 0.002 & & 0.005 & 0.023 & & & \\
\hline $\mathrm{Pb}$ & 2.28 & 1.71 & 1.59 & 0.154 & 1.69 & 1.7 & 1.66 \\
\hline $\mathrm{Bi}$ & 0.031 & 0.04 & 0.04 & 0.023 & 0.048 & 0.031 & 0.034 \\
\hline $\mathrm{U}$ & 0.238 & 0.255 & 0.273 & 1.7 & 0.319 & 0.245 & 0.26 \\
\hline
\end{tabular}


Table 2d. Major and Minor Element/Al Ratios of Average Shale and Marine Sediments in ppm and Enrichment Factors in Marine Sediments

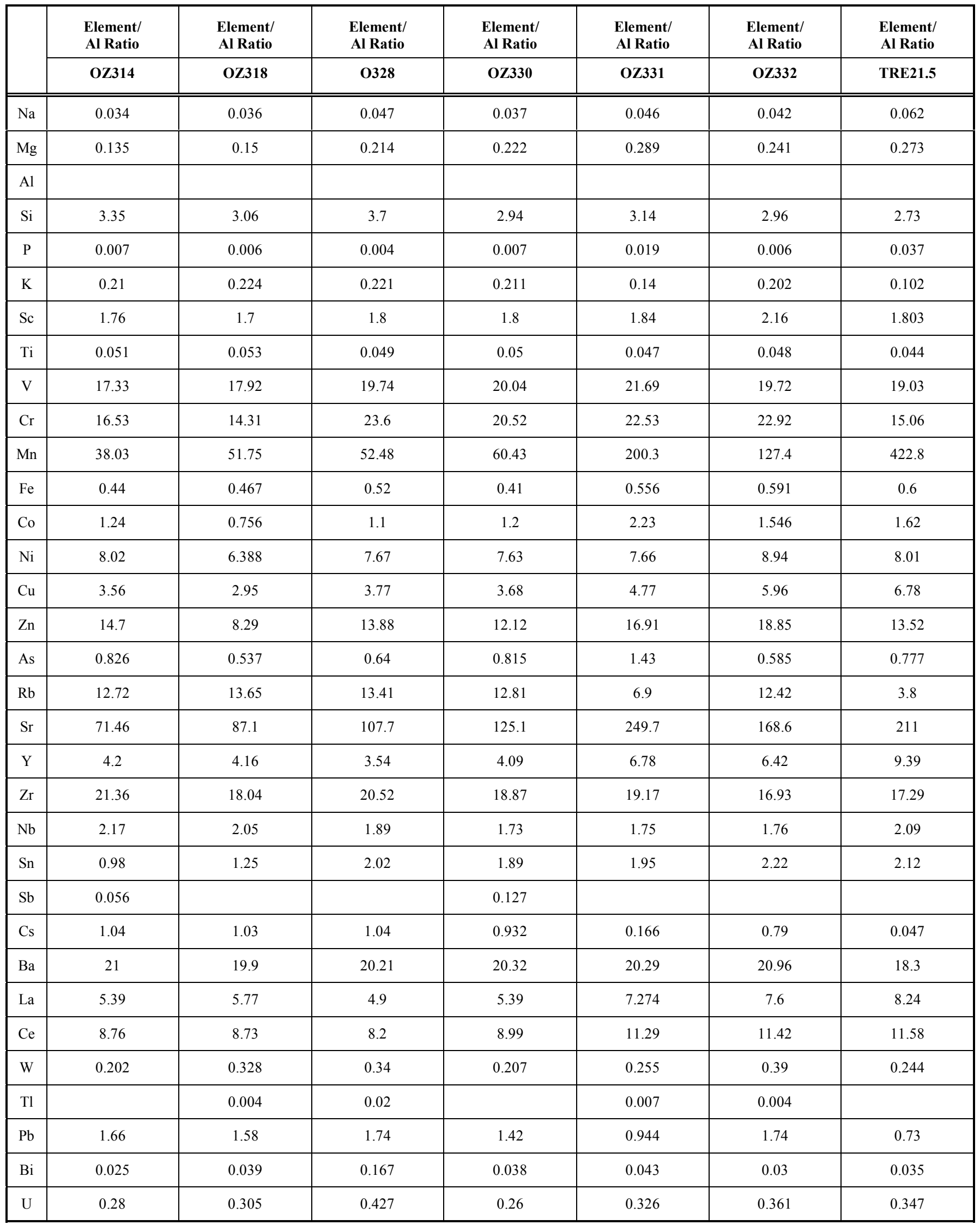


Table 2e. Major and Minor Element/Al Ratios of Average Shale and Marine Sediments in ppm and Enrichment Factors in Marine Sediments

\begin{tabular}{|c|c|c|c|}
\hline & $\begin{array}{c}\text { Element/ } \\
\text { Al Ratio }\end{array}$ & $\begin{array}{c}\text { Element/ } \\
\text { Al Ratio }\end{array}$ & $\begin{array}{c}\text { Element/ } \\
\text { Al Ratio }\end{array}$ \\
\hline & TRE32 & TRE44 & TRE72 \\
\hline $\mathrm{Na}$ & 0.906 & 0.051 & 0.041 \\
\hline $\mathrm{Mg}$ & 1.17 & 0.126 & 0.116 \\
\hline \multicolumn{4}{|l|}{$\mathrm{Al}$} \\
\hline $\mathrm{Si}$ & 4.58 & 3 & 2.66 \\
\hline $\mathrm{P}$ & 0.137 & 0.006 & 0.0003 \\
\hline K & 0.67 & 0.222 & 0.244 \\
\hline $\mathrm{Sc}$ & 4 & 1.68 & 1.64 \\
\hline $\mathrm{Cr}$ & 57.79 & 12.78 & 12.63 \\
\hline $\mathrm{Mn}$ & 1650.9 & 80.62 & 96.2 \\
\hline $\mathrm{Fe}$ & 0.408 & 0.44 & 0.53 \\
\hline Co & 5.36 & 2.18 & 1.81 \\
\hline $\mathrm{Ni}$ & 101.9 & 8.85 & 9.47 \\
\hline $\mathrm{Cu}$ & 389.5 & 3.7 & 5.76 \\
\hline $\mathrm{Zn}$ & 253.15 & 10.02 & 13.81 \\
\hline $\mathrm{Nb}$ & 319.8 & 2.29 & 2.43 \\
\hline $\mathrm{Sn}$ & 24.73 & 1.06 & 1.07 \\
\hline $\mathrm{Sb}$ & & & 0.054 \\
\hline Cs & 1.47 & 1.02 & 1.17 \\
\hline $\mathrm{Ba}$ & 178 & 20.71 & 21.36 \\
\hline $\mathrm{La}$ & 38.74 & 4.49 & 4.83 \\
\hline $\mathrm{Ce}$ & 38.22 & 8.35 & 8.3 \\
\hline W & 28.04 & 0.252 & 0.184 \\
\hline $\mathrm{Tl}$ & & 0.001 & \\
\hline $\mathrm{Pb}$ & 91.34 & 1.65 & 1.853 \\
\hline $\mathrm{Bi}$ & 1.63 & 0.032 & 0.031 \\
\hline $\mathrm{U}$ & 2.03 & 0.262 & 0.247 \\
\hline
\end{tabular}


Table 2f. Major and Minor Element/Al Ratios of Average Shale and Marine Sediments in ppm and Enrichment Factors in Marine Sediments

\begin{tabular}{|c|c|c|c|c|c|c|c|c|}
\hline & $\begin{array}{c}\text { EF } \\
\text { TR2 }\end{array}$ & $\begin{array}{c}\text { EF } \\
\text { TR7 }\end{array}$ & $\begin{array}{c}\text { EF } \\
\text { TR14 }\end{array}$ & $\begin{array}{c}\text { EF } \\
\text { TR19 }\end{array}$ & $\begin{array}{c}\text { EF } \\
\text { TR42 }\end{array}$ & $\begin{array}{c}\text { EF } \\
\text { OZ5 }\end{array}$ & $\begin{array}{c}\text { EF } \\
\text { OZ15 }\end{array}$ & $\begin{array}{c}\text { EF } \\
\text { OZ25 }\end{array}$ \\
\hline $\mathrm{Na}$ & 0.288 & 0.284 & 0.337 & 0.338 & 0.528 & 0.327 & 0.474 & 0.456 \\
\hline $\mathrm{Mg}$ & 0.637 & 1.08 & 1.2 & 0.919 & 2.52 & 0.672 & 0.914 & 1.06 \\
\hline \multicolumn{9}{|l|}{$\mathrm{Al}$} \\
\hline $\mathrm{Si}$ & 0.752 & 0.733 & 0.782 & 0.787 & 0.94 & 1.22 & 1.27 & 1.32 \\
\hline $\mathrm{P}$ & 0.519 & 0.878 & 0.532 & 1.04 & 2.26 & 0.341 & 57.49 & 0.708 \\
\hline $\mathrm{K}$ & 0.656 & 0583 & 0.628 & 0.629 & 0.425 & 0.599 & 0.615 & 0.605 \\
\hline $\mathrm{Sc}$ & 1.03 & 1.1 & 1.12 & 1.04 & 1.33 & 1.12 & 1.6 & 1.38 \\
\hline $\mathrm{Ti}$ & 0.856 & 0.857 & 0.855 & 0.841 & 0.758 & 1.04 & 1.14 & 1.02 \\
\hline $\mathrm{V}$ & 0.97 & 1.16 & 1.19 & 0.951 & 1.33 & 1.11 & 1.3 & 1.15 \\
\hline $\mathrm{Cr}$ & 1.79 & 1.5 & 1.51 & 1.37 & 2.65 & 1.5 & 1.53 & 1.76 \\
\hline $\mathrm{Mn}$ & 0.562 & 0.882 & 1.06 & 1.48 & 6.44 & 0.56 & 1.16 & 1.79 \\
\hline $\mathrm{Fe}$ & 0.665 & 0.782 & 0.833 & 1.28 & 2.15 & 0.821 & 1.13 & 2.95 \\
\hline Co & 0.703 & 0.833 & 0.851 & 0.64 & 0.577 & 0.711 & 0.558 & 0.61 \\
\hline $\mathrm{Ni}$ & 1.087 & 0.963 & 1.28 & 0.928 & 1.51 & 1.17 & 1.2 & 1.39 \\
\hline $\mathrm{Cu}$ & 0.454 & 0.528 & 0.524 & 0.578 & 1.71 & 0.696 & 0.658 & 0.759 \\
\hline $\mathrm{Zn}$ & 0.801 & 0.938 & 1.06 & 0.821 & 2.97 & 1.18 & 1.79 & 1.52 \\
\hline As & 1.034 & 1.41 & 1.06 & 0.582 & 0.577 & 0.542 & 1.05 & 0.714 \\
\hline $\mathrm{Rb}$ & 0.768 & 0.752 & 0.765 & 0.734 & 0.522 & 0.718 & 0.696 & 0.743 \\
\hline $\mathrm{Sr}$ & 1.12 & 2.68 & 3.44 & 2.14 & 11.76 & 5.53 & 5.23 & 2.37 \\
\hline $\mathrm{Y}$ & 0.538 & 0.878 & 0.81 & 0.744 & 2.57 & 0.662 & 6.54 & 0.846 \\
\hline $\mathrm{Zr}$ & 0.893 & 0.888 & 0.884 & 0.839 & 0.874 & 1.32 & 1.96 & 1.325 \\
\hline $\mathrm{Nb}$ & 0.892 & 0.831 & 0.861 & 0.851 & 0.79 & 1.13 & 1.52 & 1.12 \\
\hline Sn & 1.05 & 1.61 & 1.91 & 1.34 & 5.48 & 1.12 & 1.32 & 2.566 \\
\hline $\mathrm{Sb}$ & & 0.326 & & & & & & \\
\hline Cs & 1.5 & 1.13 & 1 & 1.38 & 0.582 & 1.36 & 1.31 & 1.44 \\
\hline $\mathrm{Ba}$ & 0.332 & 0.312 & 0.286 & 0.335 & 0.598 & 0.34 & 0.321 & 0.332 \\
\hline $\mathrm{La}$ & 0.849 & 1.14 & 1.12 & 1.02 & 2.33 & 0.99 & 7.31 & 1.11 \\
\hline $\mathrm{Ce}$ & 0.688 & 0.837 & 0.806 & 0.798 & 1.15 & 0.77 & 7.05 & 0.844 \\
\hline W & 0.866 & 1.01 & 0.999 & 0.807 & 4.04 & 0.99 & 1.03 & 1.07 \\
\hline $\mathrm{Tl}$ & 0.06 & & 0.028 & & & 0.048 & & 0.095 \\
\hline $\mathrm{Pb}$ & 0.624 & 0.69 & 0.656 & 0.503 & 0.281 & 0.783 & 0.617 & 0.851 \\
\hline $\mathrm{Bi}$ & 2.78 & 2.81 & 3.21 & 2.28 & 5.04 & 2.44 & 4.9 & 3.53 \\
\hline $\mathrm{U}$ & 0.517 & 0.62 & 0.621 & 0.536 & 0.733 & 0.609 & 1.2 & 0.634 \\
\hline
\end{tabular}


Table 2g. Major and Minor Element/Al Ratios of Average Shale and Marine Sediments in ppm and Enrichment Factors in Marine Sediments

\begin{tabular}{|c|c|c|c|c|c|c|c|c|}
\hline & $\begin{array}{c}\text { EF } \\
\text { OZ34 }\end{array}$ & $\begin{array}{c}\text { EF } \\
\text { OZ239 }\end{array}$ & $\begin{array}{c}\text { EF } \\
\text { OZ265 }\end{array}$ & $\begin{array}{c}\text { EF } \\
\text { OZ272 }\end{array}$ & $\begin{array}{c}\text { EF } \\
\text { OZ279 }\end{array}$ & $\begin{array}{c}\text { EF } \\
\text { OZ285 }\end{array}$ & $\begin{array}{c}\text { EF } \\
\text { OZ289 }\end{array}$ & $\begin{array}{c}\text { EF } \\
\text { OZ294 }\end{array}$ \\
\hline $\mathrm{Na}$ & 0.347 & 0.308 & 0.308 & 0.276 & 0.33 & 0.29 & 0.265 & 0.284 \\
\hline $\mathrm{Mg}$ & 0.68 & 1.34 & 0.704 & 0.693 & 0.99 & 0.725 & 0.632 & 0.662 \\
\hline \multicolumn{9}{|l|}{$\mathrm{Al}$} \\
\hline $\mathrm{Si}$ & 1.21 & 1.04 & 1.065 & 0.95 & 0.93 & 0.993 & 0.952 & 1.08 \\
\hline $\mathrm{P}$ & 0.779 & 0.811 & 0.619 & 0.331 & 0.813 & 0.4 & 0.451 & 0.561 \\
\hline $\mathrm{K}$ & 0.654 & 0.523 & 0.66 & 0.621 & 0.684 & 0.796 & 0.798 & 0.77 \\
\hline $\mathrm{Sc}$ & 1.24 & 1.36 & 1.25 & 0.99 & 1.4 & 1.13 & 1.24 & 1.21 \\
\hline $\mathrm{Ti}$ & 1.05 & 0.882 & 1.12 & 0.97 & 1.14 & 1.02 & 0.958 & 1.02 \\
\hline $\mathrm{V}$ & 1.2 & 1.4 & 1.14 & 1.07 & 1.19 & 1.14 & 1.17 & 1.27 \\
\hline $\mathrm{Cr}$ & 1.84 & 1.97 & 1.34 & 1.9 & 1.48 & 2.07 & 1.88 & 2.15 \\
\hline $\mathrm{Mn}$ & 0.5 & 1.22 & 0.378 & 0.374 & 0.478 & 0.451 & 0.405 & 0.371 \\
\hline $\mathrm{Fe}$ & 0.887 & 0.957 & 0.852 & 0.699 & 0.904 & 0.832 & 0.755 & 0.775 \\
\hline Co & 0.718 & 0.338 & 0.531 & 0.542 & 0.701 & 0.726 & 0.612 & 0.769 \\
\hline $\mathrm{Ni}$ & 1.17 & 0.959 & 1.08 & 0.864 & 0.989 & 1.14 & 0.792 & 1.198 \\
\hline $\mathrm{Cu}$ & 0.667 & 0.877 & 0.532 & 0.716 & 0.535 & 0.441 & 0.622 & 0.56 \\
\hline $\mathrm{Zn}$ & 1.1 & 1.37 & 0.871 & 1.42 & 0.869 & 1.05 & 1.47 & 1.83 \\
\hline As & 0.986 & 0.398 & 0.753 & 0.619 & 0.464 & 0.639 & 0.495 & 0.7 \\
\hline $\mathrm{Rb}$ & 0.773 & 0.557 & 0.792 & 0.838 & 0.838 & 0.914 & 0.991 & 0.914 \\
\hline $\mathrm{Sr}$ & 2.46 & 5.15 & 1.69 & 1.96 & 2.4 & 2.11 & 1.53 & 2.25 \\
\hline $\mathrm{Y}$ & 0.813 & 1.31 & 0.667 & 0.586 & 0.845 & 0.679 & 0.595 & 0.832 \\
\hline $\mathrm{Zr}$ & 1.56 & 0.922 & 1.38 & 0.965 & 1.53 & 1.2 & 0.962 & 1.21 \\
\hline $\mathrm{Nb}$ & 1.14 & 0.889 & 1.55 & 1.07 & 1.31 & 1.06 & 1.02 & 1.16 \\
\hline $\mathrm{Sn}$ & 2.22 & 2.41 & 0.944 & 1.81 & 1.14 & 2.04 & 2.07 & 2.38 \\
\hline $\mathrm{Sb}$ & 0.403 & & 0.728 & 0.342 & & & & 0.533 \\
\hline Cs & 1.49 & 0.287 & 1.62 & 1.62 & 1.65 & 1.7 & 1.85 & 1.79 \\
\hline $\mathrm{Ba}$ & 0.37 & 0.295 & 0.33 & 0.347 & 0.394 & 0.4 & 0.412 & 0.503 \\
\hline $\mathrm{La}$ & 1.21 & 1.6 & 0.992 & 0.967 & 1.23 & 1.09 & 0.987 & 1.208 \\
\hline $\mathrm{Ce}$ & 0.902 & 0.984 & 0.729 & 0.683 & 0.877 & 0.786 & 0.718 & 0.802 \\
\hline W & 0.901 & 1.18 & 1.07 & 0.942 & 1.085 & 1.04 & 1.1 & 1 \\
\hline $\mathrm{Tl}$ & 0.03 & 0.059 & 0.318 & 0.011 & 0.158 & 0.031 & & 0.067 \\
\hline $\mathrm{Pb}$ & 0.857 & 0.573 & 0.712 & 0.608 & 0.662 & 0.917 & 0.685 & 0.64 \\
\hline $\mathrm{Bi}$ & 3.01 & 3.49 & 3.525 & 2.82 & 3.59 & 2.76 & 3.502 & 3.54 \\
\hline $\mathrm{U}$ & 0.705 & 0.801 & 0.645 & 0.611 & 0.723 & 0.569 & 0.609 & 0.65 \\
\hline
\end{tabular}


Table 2h. Major and Minor Element/Al Ratios of Average Shale and Marine Sediments in ppm and Enrichment Factors in Marine Sediments

\begin{tabular}{|c|c|c|c|c|c|c|c|c|}
\hline & $\begin{array}{c}\text { EF } \\
\text { OZ300 }\end{array}$ & $\begin{array}{c}\text { EF } \\
\text { OZ301 }\end{array}$ & $\begin{array}{c}\text { EF } \\
\text { OZ306 }\end{array}$ & $\begin{array}{c}\text { EF } \\
\text { OZ310 }\end{array}$ & $\begin{array}{c}\text { EF } \\
\text { OZ314 }\end{array}$ & $\begin{array}{c}\text { EF } \\
\text { OZ318 }\end{array}$ & $\begin{array}{c}\text { EF } \\
\text { OZ328 }\end{array}$ & $\begin{array}{c}\text { EF } \\
\text { OZ330 }\end{array}$ \\
\hline $\mathrm{Na}$ & 0.356 & 0.38 & 0.239 & 0.283 & 0.25 & 0.271 & 0.351 & 0.279 \\
\hline $\mathrm{Mg}$ & 0.721 & 0.887 & 0.705 & 0.835 & 0.76 & 0.844 & 1.21 & 1.25 \\
\hline \multicolumn{9}{|l|}{$\mathrm{Al}$} \\
\hline $\mathrm{Si}$ & 1.263 & 1.26 & 1.13 & 1.13 & 1.08 & 0.982 & 1.19 & 0.945 \\
\hline $\mathrm{P}$ & 0.85 & 0.667 & 0.377 & 0.42 & 0.826 & 0.721 & 0.53 & 0.928 \\
\hline $\mathrm{K}$ & 0.683 & 0.691 & 0.772 & 0.618 & 0.62 & 0.661 & 0.653 & 0.623 \\
\hline $\mathrm{Sc}$ & 1.30 & 1.27 & 1.18 & 1.22 & 1.2 & 1.15 & 1.23 & 1.22 \\
\hline $\mathrm{Ti}$ & 1.17 & 1.12 & 0.958 & 1.04 & 0.964 & 0.995 & 0.934 & 0.946 \\
\hline $\mathrm{V}$ & 1.34 & 1.31 & 1.19 & 1.27 & 1.18 & 1.22 & 1.34 & 1.36 \\
\hline $\mathrm{Cr}$ & 1.47 & 1.52 & 2.36 & 2.09 & 1.62 & 1.41 & 2.32 & 2.02 \\
\hline $\mathrm{Mn}$ & 0.319 & 0.54 & 0.331 & 0.441 & 0.395 & 0.538 & 0.546 & 0.628 \\
\hline $\mathrm{Fe}$ & 0.882 & 0.969 & 0.732 & 0.787 & 0.809 & 0.853 & 0.952 & 0.748 \\
\hline Co & 0.778 & 0.587 & 0.426 & 0.431 & 0.577 & 0.352 & 0.513 & 0.558 \\
\hline $\mathrm{Ni}$ & 1.17 & 1.07 & 1.06 & 0.888 & 1.04 & 0.83 & 0.997 & 0.992 \\
\hline $\mathrm{Cu}$ & 0.549 & 0.555 & 0.609 & 0.543 & 0.699 & 0.578 & 0.74 & 0.723 \\
\hline $\mathrm{Zn}$ & 1.05 & 0.958 & 1.45 & 1.21 & 1.367 & 0.772 & 1.29 & 1.13 \\
\hline As & 0.962 & 0.717 & 0.66 & 0.588 & 0.73 & 0.474 & 0.565 & 0.72 \\
\hline $\mathrm{Rb}$ & 0.828 & 0.827 & 0.906 & 0.87 & 0.803 & 0.862 & 0.847 & 0.809 \\
\hline $\mathrm{Sr}$ & 2.297 & 3.02 & 1.78 & 2.34 & 2.11 & 2.57 & 3.17 & 3.69 \\
\hline $\mathrm{Y}$ & 0.848 & 0.907 & 0.686 & 0.773 & 0.906 & 0.897 & 0.763 & 0.881 \\
\hline $\mathrm{Zr}$ & 1.49 & 1.49 & 1.04 & 1.33 & 1.18 & 0.997 & 1.13 & 1.04 \\
\hline $\mathrm{Nb}$ & 1.48 & 1.43 & 1.08 & 1.08 & 1.06 & 1.01 & 0.93 & 0.85 \\
\hline $\mathrm{Sn}$ & 1.17 & 1.32 & 2.22 & 2.17 & 1.44 & 1.84 & 2.97 & 2.75 \\
\hline $\mathrm{Sb}$ & & 0.808 & & & 0.33 & & & 0.75 \\
\hline Cs & 1.69 & 1.64 & 1.83 & 1.83 & 1.67 & 1.649 & 1.67 & 1.5 \\
\hline $\mathrm{Ba}$ & 2.03 & 0.477 & 0.36 & 0.39 & 0.32 & 0.303 & 0.308 & 0.31 \\
\hline $\mathrm{La}$ & 1.18 & 1.31 & 0.98 & 1.08 & 1.19 & 1.28 & 1.083 & 1.19 \\
\hline $\mathrm{Ce}$ & 0.847 & 0.882 & 0.674 & 0.75 & 0.815 & 0.812 & 0.762 & 0.836 \\
\hline W & 1.2 & 1.06 & 1.28 & 1.19 & 1.16 & 1.609 & 1.67 & 1.02 \\
\hline $\mathrm{Tl}$ & 0.293 & & & & 0.042 & 0.055 & 0.257 & 0.088 \\
\hline $\mathrm{Pb}$ & 0.062 & 0.677 & 0.681 & 0.666 & 0.721 & 0.637 & 0.7 & 0.379 \\
\hline $\mathrm{Bi}$ & 1.99 & 4.24 & 2.77 & 2.21 & 2.21 & 3.48 & 14.75 & 3.34 \\
\hline $\mathrm{U}$ & 4.06 & 0.761 & 0.585 & 0.621 & 0.658 & 0.728 & 1.02 & 0.622 \\
\hline
\end{tabular}


Table 2i. Major and Minor Element/Al Ratios of Average Shale and Marine Sediments in ppm and Enrichment Factors in Marine Sediments

\begin{tabular}{|c|c|c|c|c|c|c|}
\hline & $\begin{array}{c}\text { EF } \\
\text { OZ331 }\end{array}$ & $\begin{array}{c}\text { EF } \\
\text { OZ332 }\end{array}$ & $\begin{array}{c}\text { EF } \\
\text { TRE21.5 }\end{array}$ & $\begin{array}{c}\text { EF } \\
\text { TRE32 }\end{array}$ & $\begin{array}{c}\text { EF } \\
\text { TRE44 }\end{array}$ & $\begin{array}{c}\text { EF } \\
\text { TRE72 }\end{array}$ \\
\hline $\mathrm{Na}$ & 0.342 & 0.309 & 0.458 & 6.75 & 0.377 & 0.306 \\
\hline $\mathrm{Mg}$ & 1.63 & 1.36 & 1.54 & 6.59 & 0.709 & 0.653 \\
\hline \multicolumn{7}{|l|}{$\mathrm{Al}$} \\
\hline $\mathrm{P}$ & 2.43 & 0.756 & 4.63 & 17.33 & 0.778 & 0.345 \\
\hline K & 0.42 & 0.598 & 0.3 & 1.98 & 0.658 & 0.721 \\
\hline $\mathrm{Sc}$ & 1.25 & 1.47 & 1.23 & 2.72 & 1.14 & 1.12 \\
\hline $\mathrm{Ti}$ & 0.896 & 0.9 & 0.832 & 187.28 & 1.01 & 0.978 \\
\hline $\mathrm{Mn}$ & 2.08 & 1.33 & 4.4 & 17.17 & 0.838 & 1 \\
\hline $\mathrm{Fe}$ & 1.02 & 1.08 & 1.1 & 0.748 & 0.801 & 0.975 \\
\hline Co & 1.04 & 0.719 & 0.751 & 2.5 & 1.01 & 0.844 \\
\hline $\mathrm{Ni}$ & 0.996 & 1.16 & 1.04 & 13.25 & 1.15 & 1.231 \\
\hline $\mathrm{Cu}$ & 0.937 & 1.17 & 1.33 & 76.51 & 0.727 & 1.131 \\
\hline $\mathrm{Zn}$ & 1.57 & 1.75 & 1.26 & 23.55 & 0.932 & 1.29 \\
\hline As & 1.26 & 0.517 & 0.687 & 30 & 2.04 & 0.746 \\
\hline $\mathrm{Nb}$ & 0.859 & 0.865 & 1.028 & 157.02 & 1.12 & 1.19 \\
\hline Sn & 2.87 & 3.26 & 3.13 & 36.43 & 1.56 & 1.58 \\
\hline $\mathrm{Sb}$ & & & & & & 0.318 \\
\hline Cs & 0.266 & 1.28 & 0.075 & 2.39 & 1.64 & 1.88 \\
\hline $\mathrm{Ba}$ & 0.309 & 0.319 & 0.279 & 2.71 & 0.316 & 0.325 \\
\hline $\mathrm{La}$ & 1.61 & 1.68 & 1.82 & 8.56 & 1.01 & 1.07 \\
\hline $\mathrm{Ce}$ & 1.05 & 1.06 & 1.08 & 3.56 & 0.777 & 0.772 \\
\hline $\mathrm{W}$ & 1.25 & 1.91 & 1.2 & 137.7 & 1.24 & 0.903 \\
\hline $\mathrm{Tl}$ & 0.088 & 0.046 & & 1.57 & 0.014 & \\
\hline $\mathrm{Pb}$ & 0.379 & 0.7 & 0.293 & 36.7 & 0.663 & 0.744 \\
\hline $\mathrm{Bi}$ & 3.79 & 2.65 & 3.12 & 143.88 & 2.87 & 2.72 \\
\hline $\mathrm{U}$ & 0.779 & 0.862 & 0.83 & 4.84 & 0.626 & 0.59 \\
\hline
\end{tabular}


an EF of 1 with the exception in the uppermost part of the profile. $\mathrm{Bi}$ is constantly enriched within the whole profile with a distinct peak in EF again in the "Argovien". $\mathrm{Zn}$ is enriched to a certain extent within the lowermost part of the profile as well as in the "Argovien". The few measurements of $\mathrm{Sb}$ and $\mathrm{Tl}$ indicate depletion of these elements throughout.

\section{DISCUSSION}

The fluctuation in concentrations of the main elements like $\mathrm{Na}, \mathrm{Mg}, \mathrm{Al}, \mathrm{Si}$ and $\mathrm{K}$ are very similar and point to an external source (aeolian and fluvial) of these elements. Moreover, those elements are the main constituents in rocks of terrestrial provenance. $\mathrm{Al}$ is the most important element essentially not affected by biological or diagenetic processes in marine environments. Biogenic remnants in marine sediments often contain $\mathrm{Si}, \mathrm{K}, \mathrm{Mg}$, and $\mathrm{Na}$ [21]. The main elements, therefore, are not suitable for the use as palaeoproxies.

By far the most extensively studied trace elements in marine sediments are $\mathrm{Fe}$ and $\mathrm{Mn}$ (e.g. [4, 7-9, 12, 18, 20, 21, 26, 29, 31, 40-45]). According to Bruland [21] Mn occurs dissolved in the sea in the +2 oxidation state and tends to form relatively weak complexes in seawater mostly like the free hydrated $\mathrm{Mn}^{2+}$ or $\mathrm{MnCl}^{+}$. In oxygenated seawater $\mathrm{Mn}(\mathrm{II})$ is thermodynamically unstable and tends to form insoluble manganese oxides. $\mathrm{Mn}$ is mainly delivered to the ocean by external input sources (physical weathering, erosion of rocks, aeolian and fluvial transport) which lead to maxima in the surface waters, in the oxygen-minimum zone. Other mechanisms of Mn input consist of remobilization of $\mathrm{Mn}$ from sediments and hydrothermal flux. The high solubility of $\mathrm{Mn}^{2+}$ in sediments deposited under reducing conditions may result in Mn being depleted in the sediment if fixation in carbonate minerals does not occur [9]. Mn redox cycling is inasmuch important for trace-metal enrichment in suboxic-anoxic systems because it can trigger and/or accelerate the transfer of trace elements from seawater to the sediment (e.g. adsorption of trace metals onto Mn-oxyhydroxides) as well as the diagenetic remobilization of trace elements within the sediment [e.g. 17, 19].

$\mathrm{Fe}$ - the most abundant metal in the Earth's crust - is stable as Fe(III) in oxygenated seawater. Dissolved Fe(III), due to its strong tendency to hydrolyze, exists in seawater mainly as $\mathrm{Fe}(\mathrm{OH})_{3}^{0}$ and $\mathrm{Fe}(\mathrm{OH})^{2+}$. $\mathrm{Fe}(\mathrm{III})$ preferably precipitates as hydrous iron oxide. Fe(II) exists as a stable form in anaerobic waters as the free ion or $\mathrm{FeCl}^{+}$. Fe features a similar pattern of redox cycling to Mn although with a remarkable difference: $\mathrm{Fe}$ is systematically involved in $\mathrm{Fe}-$ sulfide precipitation within reducing sediments and waters and is sequestered in Fe-carbonates (i.e., siderite) only under special conditions. The natural input of $\mathrm{Fe}$ is dominated by particulate transport from the continents in the form of suspended material in rivers or aeolian dust, input as complexes, colloids and particles $<0.45 \mu \mathrm{m}$ and hydrothermal flux $[8,21,31]$. The major sink of $\mathrm{Fe}$ in the oceanic (hemipelagic and pelagic) environment is the formation of Fe-sulfides in reducing sediments. The most striking feature within the Oxfordian sediments from Trescléoux and Oze concerning $\mathrm{Fe}$ and $\mathrm{Mn}$ is the correlation of the enrichment of these two elements with the positive $\partial^{13} \mathrm{C}$ excursion in the upper part of the profile ("Argovien"). This correlation of the $\partial^{13} \mathrm{C}$ excursion with trends in $\mathrm{Mn}$ and Fe contents seems to reflect changes in the Oxfordian palaeooceanography and climate. High concentrations of Mn of the early Toarcian, Late Jurassic, Aptian, Albian, Cenomanian/Turonian boundary and Miocene seem to be correlated with ocean-wide anoxia (Oceanic Anoxic Events OAE) and/or changes in the carbon cycle as expressed by positive $\partial^{13} \mathrm{C}$ excursions (e.g. [31, 32, 46-49]) within hemipelagic to pelagic environments [1]. The climate during the Oxfordian was undergoing major changes, during this time interval a transition of a cold and humid period to a considerably warmer and more arid climate proceeded. This change led to increased metal flux from the continent due to the intensified chemical weathering, triggered by the onset of intensified greenhouse climate conditions recorded by the perturbation of the $\mathrm{C}$-isotope curve. The turning point of the excursion coincides with a major change in Tethyan sedimentation pattern [1]. According [2] there is no evidence for large-scale volcanism during the Oxfordian.

Other redox-sensitive elements include $\mathrm{V}, \mathrm{Cr}, \mathrm{Co}, \mathrm{Ni}$ and $\mathrm{U} . \mathrm{V}$ is present in oxygenated seawater in +5 oxidation state, mainly as $\mathrm{VO}_{2}^{2+}$ and $\mathrm{HV}_{2} \mathrm{O}_{4}^{-}$. Under anoxic conditions it is reduced to the oxovanadium (IV) ion, $\mathrm{VO}_{2}^{2+}$ [21]. In pelagic and hemipelagic sediments, $\mathrm{V}$ is tightly coupled with the redox cycle of $\mathrm{Mn}$ [50]. Vanadate readily adsorbs onto both $\mathrm{Mn}$ - and Fe-oxyhydroxides [8]. $\mathrm{U}$ in seawater is present mainly as $\mathrm{U}(\mathrm{VI})$ in the conservative form of uranyl ions that bind to carbonate ions, forming $\mathrm{UO}_{2}(\mathrm{CO})_{3}^{4-}$.

Reduction of $\mathrm{U}$ (VI) to $\mathrm{U}(\mathrm{IV})$ occurs under conditions similar to those of $\mathrm{Fe}(\mathrm{III})$ to $\mathrm{Fe}(\mathrm{II})$ [51-53]. In the reduced state, removal of $U$ from the water column and accumulation into the sediment is at least partly mediated by bacterial sulfate reduction reactions, because without bacterial activity, the reduction process would be very slow [53, 54]. In Tribovillard et al. [19] an interesting aspect of the geochemistry of $U$ is pointed out. As the intensity of sulfate reduction activity is linked to the abundance of reactive organic matter (bacteria), U abundance usually shows a good correlation with the organic carbon rain rate and with the organic-carbon content in anoxic (non-sulfidic) facies. Another fact of the geochemistry of $\mathrm{V}$ and $\mathrm{U}$ deserves mentioning as well: Both elements are reduced and can accumulate under denitrifying conditions, whereas $\mathrm{Ni}$, Co, $\mathrm{Cu}, \mathrm{Zn}, \mathrm{Cd}$ and $\mathrm{Mo}$ are enriched mainly under sulfatereducing (euxinic) conditions alone [8, 15, 18, 23, 25]. Using the contrasting behavior of these two groups of trace elements, it may be possible to recognize redox gradations in some sedimentary systems. For example, in the case of $U$ and $\mathrm{V}$ enrichment without Mo enrichment, suboxic/anoxic depositional without free $\mathrm{H}_{2} \mathrm{~S}$ can be inferred. Conversely, sediments exhibiting concurrent enrichments in $\mathrm{U}, \mathrm{V}$ and Mo reflect euxinic conditions at the sediment-water interface or in the water column $[18,23,55,56]$.

As $\mathrm{Mo}$ and $\mathrm{Cd}$ are not detectable (e.g. both elements are well below LOD) in the marine sediments from both Trescléoux and Oze, euxinic conditions at the time of deposition can be excluded. V and U both exhibit the typical peak within positive $\partial^{13} \mathrm{C}$ excursion in the upper part of the 
profile and this fact can be taken as a good indication for an OAE. $V$ and $U$ both have in common that there is no detrital influence to their concentration in marine sediments. As already mentioned above, the turning point of the isotope excursion coincides with a major change in the Tethyan sedimentation pattern [1-3]. This was also the time of a profound rearrangement of the oceanic current system induced by the establishment of a new circum-global ocean passage in low latitudes. This modification very likely increased temperatures by about $5^{\circ} \mathrm{C}$ in middle latitudes and increased nutrient concentrations in surface water due to intensified upwelling. The result was an increased $\mathrm{C}_{\text {org }}$ production and burial, leading to the positive excursion in $\mathrm{C}$ isotope records as ${ }^{12} \mathrm{C}$ was preferentially removed from the ocean system $([1,2]$ and references therein).

$\mathrm{Cr}, \mathrm{Co}$ and $\mathrm{Ni}$ represent redox-sensitive trace elements as well and display a similar distribution pattern to $\mathrm{U}$ and $\mathrm{V}$ but exhibit greater fluctuations within the middle part of the profile. In oxygenated seawater, $\mathrm{Cr}$ is present primarily as $\mathrm{Cr}(\mathrm{VI})$ in the chromate anion. Under usual seawater conditions, the chromate anion is soluble, but under anoxic conditions, $\mathrm{Cr}(\mathrm{IV})$ is reduced to $\mathrm{Cr}(\mathrm{III})$, forming aquahydroxyl cations and hydroxyl cations which can readily be adsorbed to Fe- and Mn-oxyhydroxides [8, 21]. Thus, $\mathrm{Cr}$ is exported to the sediments. More over, $\mathrm{Cr}$ may be transported to the sediment with the land-derived clastic fraction (e.g., chromite, clay minerals, ferromagnesian minerals in which $\mathrm{Cr}$ substitutes readily for $\mathrm{Mg}[6,9,57]$. Thus, the complexities of $\mathrm{Cr}$ transport and enrichment limits its palaeoenvironmental utility.

$\mathrm{Co}$ and Ni can both be incorporated into pyrite, the most common sulfide in the marine sediments taken for this study. In oxic environments, Co is present as the dissolved cation, $\mathrm{Co}^{2+}$. In anoxic waters, Co forms the insoluble sulfide $\mathrm{CoS}$, which can be taken up in solid solution by authigenic Fesulfides [21]. Co is partially tied to the abundance of clastic material which limits its use as a reliable redox proxy. In oxic marine environments, $\mathrm{Ni}$ behaves as a micronutrient and may be present as soluble $\mathrm{Ni}^{2+}$ cations or $\mathrm{NiCl}^{+}$ions but it is mostly present as a soluble $\mathrm{Ni}$ carbonate $\left(\mathrm{NiCO}_{3}\right)$ or adsorbed onto humic and fulvic acids [8]. Ni does not show any significant enrichment in the sediments from Trescléoux and Oze, thus again excluding euxinic conditions at the time of deposition.

$\mathrm{P}$ is essential to all forms of life on Earth and plays a fundamental role in metabolic processes and is a major constituent of skeletal material. $\mathrm{P}$ distributions in sediments are linked to the supply of OM (organic matter), commonly resulting from high productivity [19]. Usually, $\mathrm{P}$ is released as $\mathrm{PO}_{4}^{3-}$ from decaying $\mathrm{OM}$ during oxic, suboxic and anoxic bacterial degradation below the sediment-water interface. $\mathrm{P}$ remineralized to pore waters can either be released from the sediment back to the water column or can be reprecipitated within the sediment (e.g. [58]). Under certain conditions, P once released to pore water can reach relatively high concentrations and authigenic phases can precipitate. The principal authigenic phases belong to the apatite family. A prerequisite for precipitation is supersaturation of $\mathrm{P}$.

High productivity is not always considered necessary for an enrichment of P. In low productivity areas of the oceans,
$\mathrm{P}$ accumulation can be achieved through redox cycling of $\mathrm{Fe}$, with $\mathrm{P}$ sorption onto Fe-oxyhydroxide coatings and Fe-P coprecipitation (e.g. [59]). As mentioned by [60] Mn can also be involved in $\mathrm{P}$ enrichment. Thus, in the case of $\mathrm{P}$ trapping in sediments, the abundance of $\mathrm{P}$ is not necessarily indicative of a high productivity area. $\mathrm{P}$ can also be retained as a reactive fraction in the sediments which depend highly on the redox conditions of the depositional system. The elevated concentration in the sediments from Trescléoux and Oze in the "Argovien" (upper positive $\partial^{13} \mathrm{C}$ excursion) coincide precisely with the peaks of $\mathrm{Fe}$ and $\mathrm{Mn}$. Anoxic conditions are indicated by $\mathrm{Fe}, \mathrm{Mn}$ and $\mathrm{P}$, although the influence of high productivity cannot be excluded. The high concentration of the nutrient related element $\mathrm{P}$ in the lowermost part of the Oze section suggests a more oligotrophic setting with an elevated biological productivity $[9,25]$. As the principal authigenic phases belong to the apatite family, many elemental (major and trace elements) substitutions can occur in the two $\mathrm{Ca}$ sites as well as in the $\mathrm{PO}_{4}$ and $\mathrm{F}$ site or may be adsorbed onto the crystal surface.

Elements showing marked enrichments within the marine sediments of southern France include $\mathrm{Y}$, the rare earth elements and accessorily $\mathrm{Cu}, \mathrm{Cr}, \mathrm{Pb}$ and $\mathrm{V}$ [61]. Sc, Y, La and $\mathrm{Ce}$ have very similar chemical and physical properties due to the fact that they all form stable $3^{+}$ions of similar size. Ce also exists in the $4^{+}$state and, therefore, redox conditions can affect its chemistry. Theoretical considerations suggest that trivalent REE should exhibit strong, predominantly electrostatic complexing with "hard" ligands such as fluoride, sulfate, phosphate, carbonate and hydroxide [62]. Enrichments of the rare earth element $\mathrm{Ce}$ incidentally seem to be indicative of anoxic conditions, too. Trends in Ce anomalies may broadly reflect changes in local oxygen availability, but this does not enable them to be used as global surface redox indicator [14]. The REEs are regarded as being almost insoluble and are present in only very low concentrations in seawater [63]. Thus, the REEs present in sediments are mainly transported as particulate matter and reflect the chemistry of their source areas. Although there was considerable research done on REE during the last decade, there is still much debate over the use of REE as palaeoproxies (e.g. [14, 64, 65].

$\mathrm{Rb}$ and $\mathrm{Sr}$ can easily substitute for $\mathrm{K}$ or $\mathrm{Ca}$ in their respective mineral phases. For $\mathrm{Rb}$ this fact is evident due to the close correlation of the distribution and peak pattern for $\mathrm{K}$ and $\mathrm{Rb}$. The latter element substitutes readily for $\mathrm{K}$ and is mainly found in the $\mathrm{K}$ feldspars and micas - the most prominent detrital minerals in the samples from southern France. The high content of $\mathrm{Sr}$ which always shows a strong correlation with $\mathrm{Ca}$ (due to its primary fixation in the lattice of calcareous skeletal material) supports the thesis of a more oligotrophic setting (similar to P) within the "Terre Noires". Ce behaves very similar to $\mathrm{Rb}$. $\mathrm{Sc}$ is to-date not known to be a palaeoproxy not being subject to chemical and/or physical fractionation and is not preferentially incorporated in any mineral phase.

Certain trace elements can stringently be used as palaeoproxies of detrital origin. One of these elements is $\mathrm{Ti}$, which is overwhelmingly of detrital origin and is usually immobile during diagenesis (see e.g. $[8,9,15]$ ). In seawater $\mathrm{Ti}$ is mainly present as Ti(IV) and the hydrolyzed species is 
the main form in aqueous solution. In Bruland [21] the author states that its concentration in seawater must be very low as the readiness with which it hydrolyses implies a very short residence time.

The heavy metals $\mathrm{Zr}, \mathrm{Nb}$ and $\mathrm{W}$ are also of detrital origin. $\mathrm{Zr}$ and $\mathrm{Nb}$ are often concentrated in heavy-metal mineral associations whereas $\mathrm{Ca}$ and $\mathrm{Sr}$ reflect the occurrence of carbonate [29]. Enhanced concentrations of $\mathrm{Zr}$ and $\mathrm{Nb}$ seem to be of volcanogenic origin $[21,25,26]$. This interpretation can be excluded as in Louis-Schmid et al. [1] the authors see no evidence for volcanism during the Oxfordian. $\mathrm{Ti}, \mathrm{Nb}$ and $\mathrm{W}$ exhibit a clear increase in concentration again within the upper part of the profile (e.g. the positive $\partial^{13} \mathrm{C}$ excursion senso stricto). Again, this correlation of the $\partial^{13} \mathrm{C}$ excursion with trends in $\mathrm{Ti}, \mathrm{Nb}$, and $\mathrm{W}$ as well as $\mathrm{Mn}$ and Fe contents seems to reflect changes in the Oxfordian palaeooceanography and climate [1-4]. The climate during the late Oxfordian was dominated by warm and arid conditions. Such conditions resulted in an increased metal flux from the continent due to the intensified chemical and physical weathering, erosion of rocks, aeolian and fluvial transport to the oceans at elevated temperatures. $\mathrm{Zr}$ shows a rather irregular pattern with regard to concentrations due to sample preparation difficulties concerning this element.

The concentrations of $\mathrm{Cu}$ and $\mathrm{As}$ are evenly distributed below the $\partial^{13} \mathrm{C}$ excursion. The usual spike within the $\partial^{13} \mathrm{C}$ excursion is evident. In oxic marine environments, $\mathrm{Cu}$ is dominantly present as organometallic ligands and, to a lesser degree, $\mathrm{CuCl}^{+}$ions present in solution $[8,21]$. Copper can behave partly as a micronutrient but can also be scavenged from solution in deep water [8] as well as be adsorbed onto particulate Fe-Mn-oxyhydroxides [66]. Under reducing conditions (notably bacterial sulfate reduction conditions), $\mathrm{Cu}(\mathrm{II})$ is reduced to $\mathrm{Cu}(\mathrm{I})$ and may be incorporated in solid solution in pyrite, or it may even form its own sulfide phases, $\mathrm{CuS}$ and $\mathrm{CuS}_{2}[67,68]$. Therefore, it is not surprising that $\mathrm{Cu}$ follows the distribution pattern of $\mathrm{Fe}$ with an enrichment in the upper part of the profile. As is similarly distributed to $\mathrm{Cu}$. As described above $\mathrm{Cu}$ as well as As can be incorporated in pyrite or may form sulfide phases of their own [69]. Both elements are affected by changing redox conditions and productivity, similarly to $\mathrm{V}$ and $\mathrm{U}$ [15] and have a nutrient type distribution. According to Warning and Brumsack [70], Bi is often enriched in sapropels. This fact possibly indicates fixation of $\mathrm{Bi}$ in anoxic waters and sediments owing to the formation of sulfides - and this is again a good indicator of an OAE.

$\mathrm{Zn}, \mathrm{Sn}$ and $\mathrm{Pb}$ do not display any distinct peak or drop in concentration within the profile. In oxic marine environments $\mathrm{Zn}$ behaves as a micronutrient, its distribution highly correlated with that of $\mathrm{Si}$ and may be present as soluble $\mathrm{Zn}^{2+}$ cations or $\mathrm{ZnCl}^{+}$ions [8, 16, 18, 21]. $\mathrm{Zn}$ is considered to be added to the sediment essentially in association with planktonic materials [6]. High concentrations of $\mathrm{Zn}$ in marine sediments are also assigned to hydrothermal input $[4,18,27,28]$. $\mathrm{Zn}$ may also be adsorbed onto particulate Fe-Mn-oxyhydroxides [71]. Under reducing conditions $\mathrm{Zn}$ may be incorporated as $\mathrm{ZnS}$ as a solid solution phase in pyrite or, to a lesser degree, it may form its own sulfides, mainly sphalerite $[67,68]$. Because of this variety of behavior of $\mathrm{Zn}$ in the marine environment, it cannot be used as a meaningful palaeoproxy. This is illustrated by the oscillating concentrations without any obvious enrichments or peaks within the profile.

$\mathrm{Sn}$ and $\mathrm{Pb}$ display a distribution pattern analogous to $\mathrm{Zn}$. Very little is known about the use of the first mentioned elements as palaeoproxies. High concentrations of $\mathrm{Pb}$ in marine sediments are often attributed to anthropogenic sources. This influence can obviously be excluded in marine sediments from the Oxfordian. $\mathrm{Sn}$ and $\mathrm{Pb}$ as well as $\mathrm{Si}$ are part of the same group of the periodic table of the elements and exist both in the $2^{+}(\mathrm{Sn}, \mathrm{Pb})$ and $4^{+}(\mathrm{Si}, \mathrm{Sn})$ oxidation state. In seawater $\mathrm{Sn}$ is present in the $4^{+}$and $\mathrm{Pb}$ in the $2^{+}$ state, predominantly as hydroxy- and chloro-complexes. Sn and $\mathrm{Pb}$ are involved in biologically mediated reactions [21]. In seawater $\mathrm{Pb}$ has a low abundance, a very short residence time, and is rapidly scavenged. Marine plankton exhibits elevated contents of $\mathrm{Pb}$. In pre-historic marine sediments $\mathrm{Pb}$ is not enriched above their lithogenic background [72].

$\mathrm{Sb}$ and $\mathrm{Tl}$ are mainly enriched in sediments formed under euxinic conditions [72] and these specific conditions can be excluded as explained above. Therefore only a few statistically relevant measurements could be performed as the concentration of $\mathrm{Sb}$ and $\mathrm{Tl}$ in the marine sediments from Trescléoux and Oze is very low.

Ba concentrations fluctuate within the lower part of the profile and increase steadily to values up to $600 \mathrm{ppm}$ within the middle before dropping again. No distinct peak within the $\partial^{13} \mathrm{C}$ excursion can be seen. Ba is occasionally of detrital provenance but is mainly present in marine sediments in detrital plagioclase crystals and as barite $\left(\mathrm{BaSO}_{4}\right)$ ([19] and references therein). Phytoplankton incorporate $\mathrm{Ba}$ and the element is released during phytoplanktonic decay and may later precipitate as barite in micro-environments where $\mathrm{Ba}$ sulfate reaches supersaturation (e.g. [73]). The apparent association of biogenic barite and OM have given support to the idea of using $\mathrm{Ba}$ as proxy for palaeoproductivity (e.g. $[73,74])$.

Many research works have dealt with the concept of using biogenic $\mathrm{Ba}$ as a palaeoproductivity proxy in older sediments (see [19] and references therein). But this approach should be used cautiously as in the case of sediments characterized by intense sulfate reduction, barite dissolution and $\mathrm{Ba}$ migration can occur (see [19] and references therein). Therefore, it is plausible that $\mathrm{Ba}$ enrichment in sediments is coupled to a high OM flux but can migrate during early diagenesis and precipitate in sediments formed under low productivity conditions. The indicated sulfate-reducing conditions can develop rapidly in OM-rich sediments - this fact is convincing enough to state that $\mathrm{Ba}$ abundance cannot be used confidently as an indicator of an enhanced palaeoproductivity in organic-rich sediments. The effectiveness of the use of the Ba palaeoproductivity marker may be restricted to marine sediments deposited in portions of the ocean with low to moderate productivity [19]. Similar to $\mathrm{P}$ the influence of a high productivity area cannot be excluded. Low to moderate productivity seems more convincing as the Ba concentration is fluctuating constantly within the whole profile. A peak in concentration appears well below the uppermost positive $\partial^{13} \mathrm{C}$ excursion (not shown in Fig. 3). 
U exhibits an identical peak at the same location as well: Sulfate reduction by organic matter (important for the $\mathrm{U}$ abundance in sediments usually exhibiting a good correlation with the organic-carbon content in anoxic (non-sulfidic facies) promotes enrichment of $\mathrm{U}$ in sediments. $\mathrm{Ba}$ enrichment is well known to be linked to high OM flux. There is a steady increase in concentration of $\mathrm{Ba}$ in the sediments from Oze peaking within sample OZ300 and an immediate drop thereafter. The drop in concentration in $\mathrm{U}$ is of the same type. The gradual, steady increase of Ba suggests a slow response of the environmental system to enhanced sulfate reduction by organic matter peaking in sample OZ300 and the sudden decline in the concentration of $\mathrm{Ba}$ as sulfate is consumed. As $\mathrm{Ba}$ can migrate during early diagenesis and precipitate in sediments formed under low productivity, the interpretation of a low productivity area in the middle part of the profile seems correct.

The inspection of the enrichment factors EF regarding the element/Al ratios of average shale compared to marine sediments substantiates the interpretation of enrichments of certain elements used as palaeoproxies for the terrigenousdetrital fraction in marine sediments: $\mathrm{P}, \mathrm{Ti}, \mathrm{Mn}, \mathrm{Fe}, \mathrm{Sr}, \mathrm{Y}$, $\mathrm{Zr}, \mathrm{Nb}, \mathrm{La}, \mathrm{Ce}, \mathrm{W}, \mathrm{Pb}$ and including $\mathrm{Sc}$ are highly enriched compared to $\mathrm{Al}$ in the average shale in the uppermost part of the profile ("Argovien"). All these elements are largely transported to the ocean by external sources. The climate during the Oxfordian was undergoing major changes with a transition of a cold and humid period to a considerably warmer and more arid climate. This change led to increased metal flux from the continent due to the intensified chemical weathering. The turning point of the excursion coincides with a major change in Tethyan sedimentation pattern $[1,2]$.

$\mathrm{V}, \mathrm{Co}$ and Ni never show a distinct enrichment except within the uppermost part of the profile. These elements are all redox-sensitive and are not part of the detrital fraction. $\mathrm{Cr}$ often exhibits enrichment factors around 2 and again a peak in EF in the "Argovien" section. Cr may be transported to the sediment with the land-derived clastic fraction but is also an indicator of anoxic environmental conditions. $\mathrm{Cu}$ and $\mathrm{As}$ commonly oscillate around an EF of 1 except in the uppermost part of the profile. Bi is constantly enriched within the whole profile with a distinct peak in EF again in the "Argovien". This again points to anoxic conditions. The few measurements of $\mathrm{Sb}$ and $\mathrm{Tl}$ indicate depletion of these elements throughout. They are both tracers for euxinic conditions and this specific environment can be excluded as explained above.

\section{SUMMARY AND CONCLUSIONS}

Certain trace elements can be used as palaeoproxies as discussed above. As the climate was undergoing major changes during the Oxfordian, the cold and humid period of the late Callovian-early Oxfordian gave way to a warmer and more arid climate in the middle-late Oxfordian. Along with the ongoing opening of the Atlantic and the Tethys, the Late Jurassic long-term sea-level rise led to a reorganization of ocean currents in the Tethys-Atlantic system during the Oxfordian. Together with the carbon isotope records of marine carbonate used as a proxy of the carbon cycle the following pattern of the above described changes could be established.
During the deposition of the so called "Terre Noires" at Trescléoux and Oze (grey to black marls, which contain layers of carbonate nodules parallel to the bedding) the high concentrations of $\mathrm{P}$ and $\mathrm{Sr}$ point to a more oligotrophic setting as $\mathrm{P}$ can be readily sorbed onto $\mathrm{Fe}$ and $\mathrm{Mn}$ oxyhydroxide coatings. This is in accordance with the high $\mathrm{Mn}$ and $\mathrm{Fe}$ concentrations in the marine sediments from these two localities. The high content of Sr, which always shows a strong correlation with $\mathrm{Ca}$, enhances the thesis of a more oligotrophic setting (similar to P) within the "Terre Noires", too. Barium enrichment in sediments is coupled to a high OM flux but Ba can migrate during early diagenesis and precipitate in sediments formed under low productivity conditions.

The high concentration peaks of $\mathrm{P}$ in the sediments of Oze and Trescléoux in the "Argovien" (upper positive $\partial^{13} \mathrm{C}$ excursion with $\partial^{13} \mathrm{C}$ values rising from 2 to $3 \%$ ) coincide precisely with the peaks of $\mathrm{Fe}$ and $\mathrm{Mn}$. Anoxic conditions are indicated by $\mathrm{Mn}, \mathrm{Fe}$ and $\mathrm{P}$ although an influence of a high productivity area concerning the $\mathrm{P}$ concentration cannot be excluded. Another stringent argument for an ocean-wide anoxia consists of the enrichment of the redox-sensitive elements $\mathrm{V}$ and $\mathrm{U}$. The latter elements are in their reduced state and can accumulate under denitrifying or anoxic conditions, whereas $\mathrm{Ni}, \mathrm{Co}, \mathrm{Cu}, \mathrm{Zn}, \mathrm{Cd}$ and $\mathrm{Mo}$ are enriched mainly under sulfate-reducing (euxinic) conditions alone. As $\mathrm{Mo}$ and $\mathrm{Cd}$ are not detectable, euxinic conditions at the time of deposition can be excluded. The low concentrations of $\mathrm{Sb}$ and Tl exclude euxinic conditions, as well.

High detrital input during the period of the upper positive $\partial^{13} \mathrm{C}$ excursion is recorded by enhanced concentrations of elements like Ti, Mn, Fe, Zr, Nb and $\mathrm{W}$. Tit, Zr, Nb and $\mathrm{W}$ are incorporated in heavy minerals and are usually immobile during diagenesis. This correlation of the $\partial^{13} \mathrm{C}$ excursion with trends in $\mathrm{Ti}, \mathrm{Nb}, \mathrm{W}$ as well as $\mathrm{Mn}$ and $\mathrm{Fe}$ contents seems to reflect changes in the Oxfordian palaeooceanography and climate as during the late Oxfordian the environmental prerequisites were controlled by warm and arid conditions and an increased metal flux from the continent due to the intensified chemical and physical weathering, erosion of rocks, aeolian and fluvial transport to the oceans.

(1) The concentration patterns of $\mathrm{P}, \mathrm{Sr}, \mathrm{Mn}, \mathrm{Fe}$ and $\mathrm{Ba}$ point to an oligotrophic setting within the sediments belonging to the "Terre Noires" facies.

An ocean-wide anoxia event within the Tethys is detected by the significant enrichment of $\mathrm{P}, \mathrm{V}, \mathrm{Mn}$, $\mathrm{Fe}$ and $\mathrm{U}$ which coincides with $\partial^{13} \mathrm{C}$ excursion of the "Argovien" facies. Due to the low abundances of Co, $\mathrm{Ni}, \mathrm{Cu}$, and $\mathrm{Zn}$ and the absence of $\mathrm{Mo}, \mathrm{Cd}, \mathrm{Sb}$ and $\mathrm{Tl}$ euxinic conditions can be excluded.

(3) High detrital input during the period of the upper positive $\partial^{13} \mathrm{C}$ excursion as well as warm and arid conditions is proved by enhanced concentrations of the elements $\mathrm{Ti}, \mathrm{Mn}, \mathrm{Fe}, \mathrm{Zr}, \mathrm{Nb}$ and $\mathrm{W}$.

\section{ACKNOWLEDGEMENTS}

Thanks go to Beat Louis-Schmid for collecting and providing the samples from Trescléoux and Oze, Marcel Guillong for the LA-ICP-MS analyses, Lydia Zehnder for 
the XRF measurements, Helmut Weissert for the scientific input and Terry Seward for the linguistic revision. The long term support from Geneviève Défago and Günter Kahr at the ETH Zürich is also acknowledged with thanks.

\section{CONFLICT OF INTEREST}

The author confirms that this article content has no conflict of interest.

\section{REFERENCES}

[1] Louis-Schmid B, Rais P, Bernasconi SM, Pellenard P, Collin PY, Weissert HJ. Detailed record of the mid-Oxfordian (Late- Jurassic) positive carbon-isotope excursion in two hemipelagic sections (France and Switzerland): A plate tectonic trigger? Palaeogeogr Palaeoclimatol Palaeoecol 2007; 248: 459-72.

[2] Louis-Schmid B, Rais P, Schaeffer P, Bernasconi SM, Weissert HJ. Plate tectonic trigger of changes in $p \mathrm{CO}_{2}$ and climate in the Oxfordian (Late Jurassic): Carbon isotope and modeling evidence. Earth Planet Sci Lett 2007; 258: 44-60.

[3] Louis-Schmid B, Rais P, Logvinovich D, Bernasconi SM, Weissert HJ. Impact of methane seeps on the local carbon-isotope record: a case study from a Late Jurassic hemipelagic section. Terr Nova 2007; 19: 259-65.

[4] Schnetger B, Brumsack HJ, Schale H, Hinrichs J, Dittert L. Geochemical characteristics of deep-sea sediments from the Arabian Sea: a high-resolution study. Deep Sea Res Part II Top Stud Oceangr 2000; 47: 2735-68

[5] Goldberg ED, Arrhenius GOD. Chemistry of pelagic sediments. Geochim Cosmochim Acta 1958; 29: 153-212.

[6] François R. A study on the regulation of the concentration of some trace elements ( $\mathrm{Rb}, \mathrm{Sr}, \mathrm{Zn}, \mathrm{Pb}, \mathrm{Cu}, \mathrm{V}, \mathrm{Cr}, \mathrm{Ni}, \mathrm{Mn}$ and $\mathrm{Mo}$ ) in Saanich Inlet sediments, British Columbia, Canada. Mar Geol 1988; 83: 285308.

[7] Shaw TJ, Gieskesm JM, Jahnke RA. Early diagenesis in differing depositional environments: The response of transition metals in pore water. Geochim Cosmochim Acta 1990; 54: 1233-46.

[8] Calvert SE, Pedersen TF. Geochemistry of recent oxic and anoxic marine sediments: implications for the geological record. Mar Geol 1993; 113: 67-88.

[9] Hild A, Brumsack HJ. Major and minor element geochemistry of lower Aptian sediments from the NW German Basin (core Hohenegglesen KB 40). Cretaceous Res 1998; 19: 615-33.

[10] Brumsack HJ, Wehausen R. A. Geochemical record of precessioninduced cyclic Eastern Mediterranean sedimentation: Implications for Northern Sahara humidity during the Pliocene. Naturwissenschaften 1999; 86: 281-6.

[11] Morford JL, Emerson S. The geochemistry of redox sensitive trace metals in sediments. Geochim Cosmochim Acta 1999; 63: 1735-50.

[12] Wehausen R, Brumsack HJ. Cyclic variations in the chemical composition of eastern Mediterranean Pliocene sediments: a key for understanding sapropel formation. Mar Geol 1999; 153: 161-76.

[13] Dellwig O, Watermann F, Brumsack HJ, Gerdes G, Krumbein WE. Sulphur and iron geochemistry of Holocene coastal peats (NW Germany): a tool for palaeoenvironmental reconstruction. Palaeogeogr Palaeoclimatol Palaeoecol 2001; 167: 359-79.

[14] Shields G, Stille P. Diagenetic constraints on the use of cerium

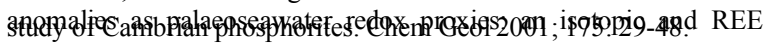

[15] Böning P, Brumsack HJ, Böttcher ME, et al. Geochemistry of Peruvian near-surface sediments. Geochim Cosmochim Acta 2004; 68: 4429-51.

[16] Babu CP, Brumsack HJ, Schnetger B, Böttcher ME. Barium as a productivity proxy in continental margin sediments: a study from the eastern Arabian Sea. Mar Geol 2002; 184: 189-206.

[17] Morford JL, Emerson SR, Breckel EJ, Kim SH. Diagenesis of oxyanions $(\mathrm{V}, \mathrm{U}, \mathrm{Re}$, and $\mathrm{Mo})$ in pore waters and sediments from a continental margin. Geochim Cosmochim Acta 2005; 69: 5021-32.

[18] Brumsack HJ. The trace metal content of recent organic carbon-rich sediments: Implications for Cretaceous black shale formation. Palaeogeogr Palaeoclimatol Palaeoecol 2006; 232: 344-61.

[19] Tribovillard N, Algeo TJ, Lyons T, Riboulleau A. Trace metals as palaeoredox and palaeoproductivity proxies: An update. Chem Geol 2006; 232: 12-32.
[20] Beck M, Dellwig O, Schnetger B, Brumsack HJ. Cycling of trace metals (Mn, Fe, Mo, U, V, Cr) in deep pore waters of interdital flat sediments. Geochim Cosmochim Acta 2008; 72: 2822-40.

[21] Bruland KW. Trace elements in seawater. Chem Oceanogr 1983; 8: 157-220.

[22] Craig PJ, Miller D. Metal ions and organometallic compounds in sea water and in sediments: biogeochemical cycles. In: Gianguzza A, Pelizzetti E, Sammartano S, Eds. Marine Chemisty. Dordrech: Kluwer Academic Publishers 1997; pp. 85-97.

[23] Rinna J, Warning B, Meyers PA, Brumsack HJ, Rullkötter J. Combined organic and inorganic geochemical reconstruction of palaeodepositional conditions of a Pliocene sapropel from the eastern Mediterranean Sea. Geochim Cosmochim Acta 2002; 66: 1969-86.

[24] Goldschmidt VM. Geochemistry. In: Muir A, Ed. The International Series of Monographs on Physics. Oxford: Clarendon Press 1954.

[25] Brumsack HJ. The inorganic geochemistry of Cretaceous black shales (DSDP Leg 41) in comparison to modern upwelling sediments from the Gulf of California. In: Summerhayes CP, Shakleton NJ, Eds North Atlantic Palaeoceanography. London, UK: Geological Society Special Publication 1986; vol. 21: pp. 447-62.

[26] Rachold V, Brumsack HJ. Inorganic geochemistry of Albian sediments from the Lower Saxony Basin NW, Germany: palaeoenvironmental constraints and orbital cycles. Palaeogeogr Palaeoclimatol Palaeoecol 2001; 174: 121-43.

[27] Bruland KW. Oceanographic distributions of cadmium, zinc, nickel, and copper in the north pacific. Earth Planet Sci Lett 1980; 47: 17698.

[28] Lipinski M, Warning B, Brumsack HJ. Trace metal signatures of Jurassic/Cretaceous black shales from the Norwegian Shelf and the Barents Sea. Palaeogeogr Palaeoclimatol Palaeoecol 2003; 190: 45975 .

[29] Dellwig O, Hinrichs J, Hild A, Brumsack HJ. Changing sedimentation in tidal flat sediments of the southern North Sea from the Holocene to the present: a geochemical approach. J Sea Res 2000; 44: 195-208.

[30] Müller B. Impact of the bacterium Pseudomonas fluorescens and its genetic derivatives on vermiculite: Effects on trace metals contents and clay mineralogical properties. Geoderma 2009; 153: 94-103.

[31] Kuhn O, Weissert HJ, Föllmi KB, Henning S. Altered carbon cycling and trace-metal enrichment during the late Valanginian and early Hauterivian. Eclogae Geol Helv 2005; 98: 333-44.

[32] Schlanger SO, Arthur MA, Jenkyns HC, Scholle PA. The Cenomanian-Turonian anoxic event, 1. stratigraphy and distribution of organic carbon rich beds and the marine $\partial^{13} \mathrm{C}$ excursions. In: Brooks J, Fleet AJ, Eds. Marine Petroleum Source Rocks. London, UK: Geological Society Special Publications 1987; vol. 26: pp. 37199.

[33] Bodin S, Godet A, Matera V, et al. Enrichment of redox-sensitive trace metals (U, V, Mo, As) associated with the late Hauterivian Faraoni oceanic anoxic event. Int $J$ Earth Sci (Geologische Rundschau) 2006; 96: 327-41.

[34] Westermann S, Föllmi KB, Adatte T, et al. The Valanginian $\delta^{13} \mathrm{C}$ excursion may not be an expression of a global oceanic anoxic event. Earth Planet Sci Lett 2010; 290: 118-31.

[35] Günther D, Frischknecht R, Heinrich CA, Kahlert HJ. Capabilities of an argon fluoride $193 \mathrm{~nm}$ excimer laser for laser ablation inductively coupled plasma mass spectrometry microanalysis of geological materials. J Anal At Spectrom 1997; 12: 939-44.

[36] Pettke T, Audétat A, Schaltegger U, Heinrich CA. Magmatic-tohydrothermal crystallization in the W-Sn mineralized Mole Granite (NSW, Australia). Chem Geol 2005; 220: 191-213.

[37] Longerich HP, Jackson SE, Günther D. Laser ablation inductively coupled plasma mass spectrometric transient signal data acquisition and analyte concentration calculation. J Anal At Spectrom 1996; 11: 899-904.

[38] Heinrich CA, Pettke T, Halter WE, et al. Quantitative multi-element analysis of minerals, fluid and melt inclusions by laser-ablation inductively-coupled mass-spectrometry. Geochim Cosmochim Acta 2003; 67: 3473-97.

[39] Müller B, Guillong M. Laser Ablation ICP-MS analyses of marine sediments from the Oxfordian (Late Jurassic): A comparison of three preparation techniques. Open Miner J 2010; 4: 9-19.

[40] Bender ML, Klinkhammer GP, Spencer DW. Manganese in seawater and the marine manganese balance. Deep-Sea Res 1977; $24: 799-812$

[41] Tebo BM, Rosson RA, Nealson KH. Potential for manganese(II) oxidation and manganese (IV) reduction to co-occur in the suboxic 
zone of the black sea. In: Izdar E, Murray JW, Eds. Black Sea Oceanography. USA: Kluwer Academic Publishers 1986; pp. 173-85.

[42] Calvert SE, Bustin RM, Ingall ED. Influence of water column anoxia and sediment supply on the burial and preservation of organic carbon in marine shales. Geochim Cosmochim Acta 1996; 60: 1577-93.

[43] Dellwig O, Watermann F, Brumsack HJ, Gerdes G. High-resolution reconstruction of a Holocene coastal sequence (NW Germany) using inorganic geochemical data and diatom inventories. Estuar Coast Shelf Sci 1999; 48: 617-33.

[44] Böning P, Cuypers S, Grunwald M, Schnetger B, Brumsack HJ. Geochemical characteristics of Chilean upwelling sediments at $\sim 36^{\circ} \mathrm{S}$. Mar Geol 2005; 220: 1-21.

[45] Collin PY, Loreau JP, Courville P. Depositional environments and iron ooid formation in condensed sections (Callovian-Oxfordian, south-eastern Paris basin, France). Sedimentology 2005; 52: 969-85.

[46] Weissert HJ. C-Isotope stratigraphy, a monitor of palaeoenvironmental change: a case study from the Early Cretaceous. Surv Geophys 1989; 10: 1-61.

[47] Weissert HJ, Lini A, Föllmi KB, Kuhn O. Correlation of Early Cretaceous carbon isotope stratigraphy and platform drowning events: a possible link. Palaeogeogr Palaeoclimatol Palaeoecol 1998; 137: 189-203.

[48] Kump LR, Arthur MA. Interpreting carbon-isotope excursions: carbonates and organic matter. Chem Geol 1999; 161: 181-98.

[49] Erba E, Bartolini A, Larson RL. Valanginian Weissert oceanic anoxic event. Geology 2004; 32: 149-52.

[50] Hastings DW, Emerson SR, Mix AC. Vanadium in foraminiferal calcite as a tracer for changes in the areal extent of reducing sediments. Palaeoceanography 1996; 11: 665-78.

[51] Zheng Y, Anderson RF, van Geen A, Kuwabara J. Authigenic molybdenum formation in marine sediments: a link to pore water sulfide in the Santa Barbara Basin. Geochim Cosmochim Acta 2000; 64: 4165-78

[52] Morford JL, Russell AD, Emerson S. Trace metal evidence for changes in the redox environment associated with the transition from terrigenous clay to diatomaceous sediments, Saanich Inlet, BC. Mar Geol 2001; 174: 355-69.

[53] McManus J, Berelson WM, Klinkhammer GP, Hammond DE, Holm C. Authigenic uranium: relationship to oxygen penetration depth and organic carbon rain. Geochim Cosmochim Acta 2005; 69: 95-108.

[54] Zheng Y, Anderson RF, van Geen A, Fleisher MQ. Remobilization of authigenic uranium in marine sediments by bioturbation. Geochim Cosmochim Acta 2002; 66: 1759-72.

[55] Tribovillard N, Riboulleau A, Lyons T, Baudin F. Enhanced trapping of molybdenum by sulfurized organic matter of marine origin as recorded by various Mesozoic formations. Chem Geol 2004; 213 : 385-401.

[56] Tribovillard N, Ramdani A, Trentesaux A. Controls on organic accumulation in Late Jurassic shales of northwestern Europe as inferred from trace-metal geochemistry. In: Harris N, Ed. The Deposition of Organic-Carbon-Rich Sediments: Models, Mechanisms, and Consequences. Tulsa: SEPM Special Publication 2005; 82: pp. 145-64.

[57] Brumsack HJ. Geochemistry of recent TOC-rich sediments from the Gulf of California and the Black Sea. Geol Rundsch 1989; 78: 85182.

[58] Kidder DL, Krishnaswamy R, Mapes RH. Elemental mobility in phosphatic shales during concretion growth and implications for provenance analysis. Chem Geol 2003; 198: 335-53.

[59] Piper DZ, Perkins RB. A modern vs Permian black shale - the hydrography, primary productivity, and water-column chemistry of deposition. Chem Geol 2004; 206: 177-97.
[60] Wang Y, van Cappellen P. A. multicomponent reactive transport model of early diagenesis: application to redox cycling in coastal marine sediments. Geochim Cosmochim Acta 1996; 60: 2993-3014.

[61] Jarvis I, Burnett WC, Nathan Y, et al. Phosphorite geochemistry: state of the art and environmental concerns. Eclogae Geol Helv 1994; 87: 643-700.

[62] Wood SA. The aqueous geochemistry of the rare-earth elements and yttrium: 1. Review of available low-temperature data for inorganic complexes and the inorganic REE speciation of natural waters. Chem Geol 1990; 82: 159-86

[63] McLennan SM. Rare earth elements in sedimentary rocks: influence of provenance and sedimentary processes. In: Lipin BR, McKay GA, Eds. Geochemistry and Mineralogy of the Rare Earth Elements. USA: Minerological Soc Am 1989; vol. 21: pp. 169-200.

[64] Hetzel A, Brumsack HJ, Schnetger B, Böttchers ME. 8. Inorganic geochemical characterization of lithologic units recovered during ODP LEG 207 (Demerata Rise). In: Mosher DC, Erbacher J, Malone MJ, Eds. Proceedings of the Ocean Drilling Program, Scientific Results. USA: College Station 2006; vol. 207, p. 37.

[65] Al-Mikhlafi AS. Rare earth elements in modern coral sands: an environmental proxy. Environ Geol 2008; 54: 1145-53.

[66] Nameroff TJ, Calvert SE, Murray JW. Glacial-interglacial variability in the eastern tropical North Pacific oxygen minimum zone recorded by redox-sensitive trace metals. Palaeoceanography 2004; 19: PA1010.

[67] Huerta-Diaz MA, Morse JW. Pyritization of trace metals in anoxic marine sediments. Geochim Cosmochim Acta 1992; 56: 2681-702.

[68] Morse JW, Luther III GW. Chemical influences on trace metalsulfide interactions in anoxic sediments. Geochim Cosmochim Acta 1999; 63: 3373-8.

[69] Sternbeck J, Sohlenius G, Hallberg RO. Sedimentary race elements as proxies to depositional changes induced by a Holocene freshbrackish water transition. Aquat Geochem 2000; 6: 325-45.

[70] Warning B, Brumsack HJ. Trace metal signatures of eastern Mediterranean sapropels. Palaeogeogr Palaeoclimatol Palaeoecol 2000; 158: 293-309.

[71] Fernex F, Février G, Benaïm J, Arnoux A. Copper, lead and zinc trapping in Mediterranean deep-sea sediments: probable coprecipitation with manganese and iron. Chem Geol 1992; 98: 293-308.

[72] Böning P, Brumsack HJ, Schnetger B, Grunwald M. Trace element signatures of Chilean upwelling sediments at $\sim 36^{\circ} \mathrm{S}$. Mar Geol 2009; 259: 112-21.

[73] Dymond J, Suess E, Lyle M. Barium in deep-sea sediments: a geochemical proxy for palaeoproductivity. Palaeoceanography 1992; 7: 163-81.

[74] McManus J, Berelson WM, Hammond DE, Klinkhammer GP. Barium cycling in the North Pacific: implication for the utility of $\mathrm{Ba}$ as a palaeoproductivity and palaeoalkalinity proxy. Palaeoceanography $1999 ; 14: 62-73$.

[75] Wedepohl KH. Environmental influences on the chemical composition of shales and clays. In: Ahrens LH, Press F, Runcorn SK, Urey HC, Eds. Physics and Chemistry of the Earth. Oxford: Pergamon 1971; vol. 8, pp. 371-99.

[76] Wedepohl KH. The composition of the upper earth's crust and the natural cycles of selected metals. Metals in natural raw materials. Natural Resources. In: Merian E, Ed. Metals and their Compounds in the Environment. Weinheim: VCH 1991; pp. 3-17.

[77] Ziegler PA. Evolution of the Arctic-North Atlantic and the Western Tethys. Am Assoc Pet Geol Mem 1988; 43: 198.

(C) Barbara Müller; Licensee Bentham Open.

This is an open access article licensed under the terms of the Creative Commons Attribution Non-Commercial License (http://creativecommons.org/licenses/by$\mathrm{nc} / 3.0 /$ ) which permits unrestricted, non-commercial use, distribution and reproduction in any medium, provided the work is properly cited. 